\title{
Gender-diverse boards and audit fees: What difference does gender quota legislation make?
}

\author{
Mehdi Nekhili a, Ammar Ali Gull ${ }^{\text {b}}$, Tawhid Chtioui ${ }^{\text {c }}$ \& Ikram Radhouane ${ }^{\text {d }}$ \\ ${ }^{a}$ Le Mans University, Avenue Olivier Messiaen, Le Mans, France \\ ${ }^{b}$ GIK Institute of Engineering Sciences and Technology, Pakistan \\ ${ }^{c}$ Emlyon Business School, France \\ ${ }^{d}$ ICD International Business School, Paris, France
}

\begin{abstract}
We investigate the effect of board (audit committee) gender diversity on audit fees in the French context. We also examine whether the relationship between the proportion of female directors (audit committee members) and audit fees is moderated by the enactment of gender quota law in 2011. We use the system GMM estimation approach on a matched sample of French firms listed in the SBF 120 stock market index between the years 2002 and 2017. Our results confirm the fact that female independent directors and female audit committee members improve board monitoring effectiveness, resulting in lower audit fees paid to incumbent auditors. Our findings also document that, while breaking the glass ceiling, the effectiveness of the gender quota law lies not in increasing the proportion of female insider directors, but in boosting the appointment of women as independent directors and as audit committee members. Using the difference-in-difference approach, our results reveal that female independent directors and female audit committee members are more willing to assert their monitoring skills after the quota law, leading to lower audit fees. Additionally, we show that, after the quota law, the negative impact on the non-audit fees is strengthened only for female independent board (audit committee) directors. Moving beyond tokenism, our results provide evidence on the importance of independence for female board (audit committee) members to assert their monitoring skills and to achieve better audit outcomes.
\end{abstract}




\section{INTRODUCTION}

The core objective of statutory audit is to protect the rights of shareholders by detecting incidents of expropriation by insiders (Newman, Patterson, \& Smith, 2005). More specifically, external auditors verify that all stakeholders are treated equally and that financial records comply with statutory requirements. In the external audit process, auditors view the board of directors as their client, because the board reviews the scope of the audit and the proposed audit fee (Blue Ribbon Committee, 1999). The board is responsible for making sure that "appropriate information and reporting systems" are in place for providing timely and accurate information to ensure corporate compliance and performance. Directors can avoid liability claims by being duly diligent and by making sure that standards are met. The board of directors generally does this by purchasing high quality audits in order to protect its reputation capital, to avoid legal liability, and to promote shareholders' interests (Carcello, Hermanson, Neal, \& Riley, 2002). Boards of directors exercise their monitoring function through independent directors and audit committees (Fama \& Jensen, 1983; Klein, 2002). In response to corporate failures such as Enron, WorldCom, and Parmalat, there has been increased interest in the role played by the board of directors (audit committees) in providing efficient monitoring. Existing studies investigate how board characteristics such as CEO duality, board independence, ownership structure, gender diversity, and constitution of the audit committee affect financial reporting quality (e.g., Carcello et al., 2002; Carcello, Hollingsworth, \& Neal, 2006; DeFond \& Francis, 2005; Gull, Nekhili, Nagati, \& Chtioui, 2018; Harjoto, Laksmana, \& Lee, 2015; Ittonen, Miettinen, \& Vähämaa, 2010; Lai, Srinidhi, Gul, \& Tsui, 2017; Mitra, Hossain, \& Deis, 2007).

In the literature, there is no consensus regarding the relationship between corporate governance effectiveness and audit fees. However, two perspectives are frequently discussed, and lead to somewhat differing results (e.g., Cohen, Krishnamoorthy, \& Wright, 2004; Hay, Knechel, \& Wong, 2006; Knechel \& Willekens, 2006; Zaman, hudaib, \& Haniffa, 2011). Audit fees may be affected by both the demand for audit services by client firm and the supply of audit services by an external auditor (Carcello et al., 2002; Harjoto et al., 2015; Ittonen et al., 2010; Lai et al., 2017). From the demand-side perspective, boards (audit committees) that are more effective are likely to demand higher audit effort resulting in higher audit fees. Conversely, firms with good governance practices may be less in need of assurance provided by external auditors, thus lowering audit fees. The supply-side argument suggests that a more effective board (audit committee) ensures the quality of firms' internal audit and internal control systems. In doing so, more effective board (audit committee) may reduce the assessed level of control risk and thereby reduce the need for assurance required from the external auditor, thus reducing audit fees (Hay et al., 2006). Although these two perspectives do not necessarily lead to the same conclusions, the demand side and supply-side arguments are not mutually exclusive (Ittonen et al., 2010). Barroso, Ben Ali, and Lesage (2018) highlight the audit setting puzzle and document that the demand side and the supply side of audit services are markedly affected by the level of agency conflicts between management and shareholders, and the degree of shareholder protection. Studying, in the French context, the effectiveness of the board (audit committee) gender diversity through the assessment of the demand and supply of external audit services might add a new piece to the puzzle.

In this study, we explore the relationship between board (audit committee) gender diversity and audit fees. Specifically, we examine the relationship between female directors (audit committee members) and audit fees by emphasizing the importance of female positions on the board. Existing studies suggest that women behave differently than men when appointed to the same positions (Adams \& Ferreira, 2009; Bennouri, Chtioui, Nagati, \& Nekhili, 2018; Harjoto et al., 2015; Lai et al., 2017). Along similar lines, empirical studies provide strong grounds for believing that female directors (audit committee members) substantially affect the fees paid to incumbent auditors (Harjoto et al., 2015; Huang, Huang, \& Lee, 2014; Ittonen et al., 2010; Lai 
et al., 2017). Four reasons can be put forward as to why our research is important. First, a main current of the corporate governance literature suggests that female directors have different monitoring behavior than male directors, exhibit higher levels of independence, and are more likely to be concerned about shareholder interests (Adams \& Ferreira, 2009; Bennouri et al., 2018; Gul, Srinidhi, \& Ng, 2011; Gull et al., 2018; Gyapong, Monem, \& Hu, 2016; Lai et al., 2017). Second, there is a consensus among scholars that female directors tend to be more risk averse and more concerned about ethical issues than men when making organizational decisions (Byrnes, Miller, \& Schafer, 1999; Schubert, 2006). In particular, female independent directors and female audit committee members help strengthen internal controls and are likely to reduce the levels of inherent and control risk (Pucheta-Martínez, Bel-Oms, \& Olcina-Sempere, 2016). Third, there has been a substantial upsurge in regulatory and academic interest in the role of board (audit committee) gender diversity in strengthening corporate governance, particularly after the enactment of gender quotas for corporate boards. Despite the recent increase in the number of female directors on corporate boards following gender quota legislation, there is a paucity of studies exploring the link between board gender diversity and audit fees.

There are few studies that empirically examine the relationship between board (audit committee) gender diversity and audit fees. Lai et al. (2017) conducted a study in a U.S. context to examine the impact of board gender diversity on audit quality, measured by audit fees and auditor choice. Their findings indicate that boards with female directors pay more for audit services and tend to appoint industry specialist auditors as opposed to boards composed solely of male directors. Another study, by Hay et al. (2006), conducted a meta-analysis of the last 25 years' audit research and revealed that the majority of studies have been conducted using Anglo-Saxon data. They also note inconsistencies, anomalies, and gaps in the existing literature and suggest studying the effects of different forms of ownership and of local institutional factors on audit fees. Our study adds to the existing literature in various ways. We examine the French context, where there is a different ownership pattern and a different legal and institutional environment from the United States and other Anglo-Saxon economies. The main features of French companies are the concentration of ownership and the separation of ownership and control (Bennouri, Nekhili, \& Touron, 2015; Faccio \& Lang, 2002; La Porta, Lopez-de-Silanes, Shleifer, \& Vishny, 1998), whereas in the U.S. ownership is dispersed. With regard to external auditing, two unique features of French companies are joint auditing (Audousset-Coulier, 2015; Bennouri et al., 2015) and the appointment of statutory auditors by the board of directors rather than by the audit committee, in accordance with Article L. 225-228 of the French Commercial Code. Our study thus augments the existing literature by providing empirical evidence on the relationship between board gender diversity and audit fees in a French context.

Following the wave of worldwide promotion of gender equality, France has implemented in January 2011 mandatory quotas to increase gender diversity on corporate boards. As a result, French firms were required to appoint at least $40 \%$ women to their board of directors by the end of 2016. Whereas firms would face serious consequences for not complying, this reform does not provide any guidelines as to the roles that should be assigned to female directors. Nevertheless, the independence of the board (e.g., Klein 2002; Carcello et al. 2006) as well as the promotion (and the characteristics) of audit committees (e.g., Turley \& Zaman, 2004; Ittonen et al., 2010; Compernolle, 2018) are premised to strengthen the corporate governance effectiveness. Consistently, both independent directorships and board committee membership are regarded as senior board positions. Since, these roles require the performance of specific tasks and duties for which the individuals concerned must have relevant expertise and skills (Nekhili \& Gatfaoui, 2013). Senior board positions such as independent directorships and audit committee membership are of central importance from the standpoint of auditing, because of the monitoring function of the board of directors. In light of the tokenism theory of Kanter (1977), we also investigate whether gender quota legislation affects board decision-making process since female directors may not be able to assert their legitimacy due to their minority 
status before the implementation of the quota law (e.g., Erkut, Kramer, \& Konrad, 2008). Consistently, we investigate whether the implementation of gender quota legislation impacts the relationship between board (audit committee) gender-diversity and audit fees and to which extent female directors may assert differently their monitoring skills in mandatory and in voluntary setting. To the best of our knowledge, no empirical evidence exists in support of the moderating role of gender quota legislation in the relationship between board (audit committee) gender diversity and audit fees.

Using a sample of the largest French firms listed in the SBF 120 stock market index from 2002 to 2017, we find that board (audit committee) gender diversity has a substantial impact on audit fees. In contrast to the study by Lai et al (2017) in the U.S. context, our findings reveal that board gender diversity is negatively correlated with the demand for audit effort, as measured by audit fees. This preliminary finding provides evidence on the differences in governance and the legal structure between the U.S and other countries. Importantly, in looking at female positions on boards of directors, we find that female independent board directors and female audit committee members, but not female insider directors, have a negative effect on audit fees. These results support the argument that the proportion of female independent directors (audit committee members) enhances the monitoring ability of the board (audit committee), resulting in the reduction of audit risk as well as the need for assurance provided by external auditors in terms of audit effort. Our study takes into account the French gender quota law enacted in January 2011, thus allowing us to examine the implications of both voluntary and mandatory board gender-diversity. Using a difference-in-difference approach, we find that the effectiveness of the gender quota law, in terms of lowering audit fees, is due to the increase in the proportion of female directors overall, but rather to the appointment of women as independent directors and as audit committee members. These results support the decision by French companies, since the coming into force of the gender quota law in 2012, to promote the proportion of female independent directors and female audit committee members at the expense of the proportion of female insider directors, suggesting the preference of French firms to more active monitoring role of female directors in a mandatory context. In a supplementary analysis, we mainly show that the level of non-audit fees is affected negatively by board (audit committee) gender diversity. The negative effect is, however, strengthened after the implementation of the gender quota law only for female independent board (audit committee) directors. Going beyond tokenism, our results provide evidence on the importance of the role assigned to female board (audit committee) members to achieve better audit outcomes.

The remainder of the paper is structured as follows. In the next section, we discuss the main features of the French setting. Section 3 presents the well-known reforms related to board gender diversity around the world. Section 4 concisely reviews the literature related to board and audit committee gender diversity with regard to audit fees paid to incumbent auditors. We then discuss our data, methodology, and variables in Section 5. In Section 6, we analyze the data and discuss our results. In the concluding section, we look at possibilities for future research.

\section{FRENCH INSTITUTIONAL BACKGROUND}

The French setting is relevant to our research question because investor protection is a serious concern in France given the country's civil law based legal system (La Porta et al., 1998). Gull et al. (2018) and Nekhili and Cherif (2011) argue that the absence of effective procedures for protecting minority shareholders provides opportunities for managers to expropriate outsiders' assets, either by manipulating earnings or by using self-dealing transactions. This situation may give rise to concerns as to the veracity of financial reports (Bushman, Chen, Engel, \& Smith, 2004). Furthermore, the concentration of ownership in the hands of families and the separation 
of ownership and control are distinctive features of the French market (Faccio \& Lang, 2002). Barroso et al. (2018) argue that ownership structure affects differently both the demand side and the supply side of audit services depending on level of agency conflicts between shareholders and management or between controlling and minority shareholders. In countries with higher ownership concentration and weaker investor protection, such as France, the main concern is to protect minority shareholders from being abused through earnings management or self-dealing transactions. It is essential to detect and punish expropriations by insiders (i.e., managers and controlling shareholders) in order to protect outside investors (Newman et al., 2005). An extensive external audit may be a good way of detecting expropriations, as well as promoting the interest of minority shareholders and enhancing the quality of financial reporting (Carcello et al., 2002).

The French external audit process differs from that of the United States and other AngloSaxon countries in at least two ways. First, joint auditing is mandatory by law in France (Audousset-Coulier, 2015; Bennouri et al., 2015). On 24 July 1966, Article 223-3 of the French Companies Act made it mandatory for listed companies and certain other companies to adopt joint audits. In joint auditing, two or more independent auditors collectively carry out, sign, and issue an audit report. Joint auditing may also have implications for investor protection, audit quality, and fees, due to the involvement of two different auditors. In contrast with US and similarly to UK, French audit committees do not choose the statutory auditors, but propose the names of external auditors for appointment or reappointment to the board of directors in accordance with Article 41 of (EU) Regulation No 537/2014 of 16 April 2014 and Article L.823-3-1 of the French Commercial Code. The choice of statutory auditors is therefore the responsibility of the board of directors rather than the audit committee. In this regard, Article L.225-228 of the French Commercial Code states that "the auditors are proposed for appointment by the general meeting in a draft resolution from the board of directors or the supervisory board. If the company's shares are admitted to trading in a regulated market, the board of directors chooses the auditors that it plans to propose". The direct involvement of the board in the process of appointing the external auditors means that we cannot limit ourselves to studying the audit committee when examining the issue of external audit in France.

Furthermore, the board of directors is perceived as an important mechanism for protecting shareholders and for ensuring the quality of financial reporting (Bedard \& Johnstone, 2004; Carcello et al., 2002). More specifically, board characteristics such as independence, expertise, and gender diversity are highly likely to promote minority shareholders' interests through their influence on external audit effort (Carcello et al., 2002; Lai et al., 2017). In support of our research question, there is considerable evidence that female directors are stricter monitors of management (Adams \& Ferreira, 2009; Gull et al., 2018), while gender diversity is associated with audit effort and, de facto, with the fees paid to their incumbent auditors (Harjoto et al., 2015; Huang et al., 2014; Ittonen et al., 2010; Lai et al., 2017).

In January 2011, the French Parliament introduced a law establishing quotas for the gender balance of company boards. The quota law was enacted in 2011 and firms had until the beginning of 2017 to make the necessary changes to their boards (Bennouri et al., 2018). The Copé-Zimmermann law states that, five years after its enactment in 2011, female directors must comprise at least $40 \%$ of board members for the largest listed and non-listed French firms (those having at least 500 employees and a turnover of more than EUR 50 million). The law was introduced in stages: from 2014, $20 \%$ of a firm's board members were required to be female, rising to $40 \%$ by the start of 2017 . Firms failing to comply with the legislation face sanctions such as fines, dissolution or a ban on the payment of directors' fees. Consistent with the tokenism theory of Kanter (1977), the introduction of the French quota legislation in January 2011 provides opportunity to question whether gender quota regulation helps female directors to assert their effective monitoring skills and to what extent the implementation of gender quota legislation impacts the relationship between board (audit committee) gender-diversity and audit 
fees.

\section{INTERNATIONAL BOARD GENDER DIVERSITY REFORMS}

It is a well-documented fact that men are dominant in boardrooms around the globe and women are under-represented compared to their proportion in the workforce (Dale-Olsen, Schøne, \& Verner, 2013; Leszczyńska, 2018; Mateos de Cabo, Terjesen, Escot, \& Gimeno, 2019; Piscopo \& Clark Muntean, 2018; Smith, 2018; Teigen, 2012). The idea of increasing the representation of women on corporate boards has gained considerable ground in the last decade. In particular, the believe that women are not suitable for placement in key positions has been extensively criticized (Nekhili, Chakroun, \& Chtioui, 2018). In 2003, women accounted for only $9 \%$ of the members of boards of directors in the 28 European Union countries. This proportion increased to $11 \%$ in 2008 and 12\% in 2010 (European Commission 2014a,b \& 2018). In June 2012, the European Commission's Network to Promote Women in Decision-Making in Politics and the Economy highlighted the importance of using women's talents in politics and the corporate world for enhancing competitiveness, dealing with economic crises and shaping a sustainable future for Europe. Disappointed by the slow advancement of women in the top tiers, the European Commission issued a Directive that urged listed companies to increase the representation of women in boardrooms to $30 \%$ by 2015 and $40 \%$ by 2020 , with the further aim of making this proposal a mandatory quota (European Commission, 2012; Leszczyńska, 2018; Smith, 2018).

In view of the sensitivity of the issue and potential discrimination in boardrooms, many countries have implemented policy reforms of one kind or another to promote gender diversity on boards of directors. These policy reforms may be categorized mainly into two types: 'mandatory' vs. 'voluntary' board gender diversity requirements. Mandatory reforms refer to gender quota legislation that can also take two forms (Mateos de Cabo et al., 2019; Terjesen, Aguilera, \& Lorenz, 2015). The first of these involves 'hard quotas', as in Norway and France. Hard quotas mean that companies failing to maintain the required number or percentage of women on the board of directors will face legal sanctions such as delisting from the stock exchange or forced dissolution. The second form is the 'soft quota', adopted by Spain and the Netherlands. In soft quota regulation, companies failing to reach the required level of board gender diversity do not face any legal sanctions and may continue to trade. However, they will not be considered for subsidies and government contracts and in the event of non-compliance will be given recommendations, warnings and reports. In extreme cases, boards that do not fulfill gender diversity appointment criteria and fail to provide satisfactory reasons for noncompliance are dissolved. Voluntary reforms, on the other hand, refer to non-binding or selfregulatory diversity requirements. States adhering to voluntary reforms, such as Australia, United Kingdom and United States, provide diversity guidelines in their codes of corporate governance and require companies either to comply with the recommendations or give their reasons for non-compliance. The voluntary approach based on the 'comply or explain' strategy is providing slow but significant improvements in the level of women board representation without introducing any binding requirements for companies (Terjesen et al., 2015). In contrast, quotas provide a 'quick fix' solution, mainly to the issue of gender balance on corporate boards (Smith, 2018).

Norway was the first state to introduce board gender quota legislation as a way to change the long-standing male dominance in the upper echelons of the corporate world. In January 2006, legislation was approved mandating that there must be at least $40 \%$ of each gender on the boards of state-owned and public limited companies by January 2008. Thereafter, noncomplying firms would face fines, delisting from the stock exchange, and dissolution. No other state has made such a success of 'hard' board gender quota legislation as Norway (Dale-Olsen et al., 2013; Teigen, 2012; Terjesen et al., 2015). Motivated by the success of Norwegian experience, in 2007 Spain became the second country to enact quota legislation requiring public 
companies to have at least $40 \%$ representation of each gender on corporate boards. Subsequently, many other countries followed Norway and Spain and introduced similar reforms. Iceland approved a law in 2010, with the target of at least $40 \%$ women on the boards of state-owned companies, public limited companies and private companies with more than fifty employees by September 2013. Similar to Spain, the Icelandic legislation does not impose any sanctions on non-complying firms, although newly formed companies are required to meet the specified level of $40 \%$ gender equality (Arnardottir \& Sigurjonsson, 2017). In 2011, a gender quota law requiring $33 \%$ representation of women on corporate boards was approved by the Belgian government in order to resolve the issue of gender diversity in the top tiers of the business world. Like in Norway and France, the Belgian government imposed sanctions on firms that do not comply with the law, in order to ensure the success of the gender quota reforms (Levrau, 2017; Terjesen et al., 2015). Following the trend, Italy also introduced on 28 June 2011 reforms for balancing the gender representation on corporate boards, which came into force on 12 August 2011. This law requires public listed companies to have a minimum representation of each gender on their board of directors. If the company still fails to comply, the elected board will be declared null (Ferrari, Ferraro, Profeta, \& Pronzato, 2018; Maida \& Weber, 2019). In 2013, the Netherlands implemented a gender quota law requiring large public and limited liability companies to appoint a minimum of $30 \%$ women to their boards (Kruisinga $\&$ Senden, 2017). This was a temporary 'soft' quota law applicable only for a period of three years, with no penalties for non-compliance, and it automatically expired on 1 January 2016. However, the reform was notably unsuccessful, since the average proportion of women on the boards of the companies concerned was only $9.6 \%$ in 2014 and $10.2 \%$ in 2016 (Kruisinga \& Senden, 2017). As with the boards of Dutch companies, men also outnumbered women in German companies. The proportion of women on the management and supervisory boards of large German companies in 2015 was approximately $6 \%$ and $20 \%$, respectively (Holst \& Kirsch, 2016). The German government introduced a quota law in 2014 requiring state-owned companies to have $30 \%$ and $50 \%$ of women on their board of directors by 2016 and 2018, respectively (Piscopo \& Clark Muntean, 2018). Two years later, in 2017, Portugal introduced gender quota legislation for listed companies, with which non-compliance may result in fines. The Portuguese gender quota law requires listed companies to have at least $33.3 \%$ women on their board of directors. In the same year, Austria also implemented a gender quota law for the supervisory boards of listed firms and those having a workforce of more than a thousand. The Austrian quota law requires the supervisory boards of the firms concerned to have at least $30 \%$ women on their boards. In the event of non-compliance with the quota law, board appointments by the Austrian firms concerned will be considered illegitimate (Mateos de Cabo et al., 2019).

Some other countries require public companies to have at least one woman on their board of directors. Israel was the first state to mandate public companies in 1999 to appoint at least one woman to their board of directors. Ten years later, in 2008, Finland introduced similar reforms for public limited companies. Then in 2012 and 2013, the requirement to have at least one woman on corporate boards of public companies was adopted by UAE and India, respectively. The most recent example of this kind of board gender quota reform is Pakistan. In May 2017, the Securities and Exchange Commission of Pakistan (SECP) required listed companies to have at least one woman director on their board within three years. Appendix 1 provides a summary of mandatory board gender diversity reforms adopted by different countries.

\section{[Please insert Appendix 1 here]}

An alternative method used by some countries to improve the representation of women on corporate boards is 'voluntary' reforms. Australia became the first country to adopt voluntary reforms in 2010 by adding a number of diversity policies in the national code of corporate governance for listed firms. This code requires listed companies to prepare and disclose their 
diversity policy as well as gender diversity objectives and progress towards achieving the set objectives. Companies are also required to disclose their board's hiring processes, the proportion of women in executive and board positions, and the proportion female employees in the company. In 2010, the proportion of women on boards of Australian companies was around $8 \%$, which increased to $15.7 \%$ in the three years up to May 2013. The figure further increased to $31.5 \%$ in large Australian companies by December 2018, as mentioned in the MSCI's recent progress report on board gender diversity, almost double the proportion in 2013. These figures show the success of board gender diversity reforms adopted by Australia. The most impressive thing is that representation of women on boards has increased without using any binding or quota legislation. Instead, the reform was solely based on 'comply or explain' principles, meaning that companies either comply or give an explanation in the event of non-compliance. ${ }^{1}$

Along similar lines, the board gender diversity policy reforms in the United Kingdom are based on non-mandatory recommendations, a self-regulatory approach and suggested targets. Women accounted for $12.5 \%$ of the board of directors of FTSE 100 companies in 2010 as compared to $9.4 \%$ in $2004 .^{2}$ Furthermore, $21 \%$ of FTSE 100 companies had no women on their board of directors, only $2 \%$ of FTSE 100 companies had a woman as the board chair, and the proportion of women among newly appointed directors was only just over than $13 \%$. Considering the slower rate of growth, Lord Davies proposed a voluntary and self-regulatory approach rather than gender quotas based on mandatory reforms. The Davies report made ten recommendations in 2011, the most notable of which was that FTSE 100 boards should increase the proportion of women to $25 \%$ by 2015 and attempt to fill $33.33 \%$ of all new board appointments with women. Two years later, in 2013, the Cranfield School of Management investigated the effect of the recommendations made by the Davies report. The Cranfield review showed that no significant progress towards the target set by the Davies report had yet been made. In particular, the review revealed that the proportion of female directors had increased to $17 \%$ and that $6 \%$ of FTSE 100 firms still have all-male boards. A 2012 review also showed that only 38 FTSE 100 firms set targets for the level of board gender diversity they aimed to achieve by 2015 . In addition, around 40 companies refused to set any targets and many firms declined to disclose their gender diversity policy or statistics relevant to the number of women at any level of the company (Choudhury, 2014). The findings of later reviews reveal that the United Kingdom's experience of voluntary board gender diversity reforms was not as successful as Australia's. A summary of countries that implemented voluntary board gender diversity reforms through suggestions or recommendations in corporate governance codes is given in Appendix 2.

\section{[Please insert Appendix 2 here]}

There are arguments for and against mandatory and voluntary board gender diversity reforms. First, mandatory reforms increase the number of female directors in a shorter period of time (e.g., Norway and France) compared to voluntary reforms (UK and Australia). Second, mandatory reforms improve the monitoring ability of boards because women tend to monitor managers more strictly than men. Third, mandatory gender diversity reforms may enhance the board's decision-making, through the opinions of diverse board members being taken into account. On the other hand, diversity can also cause communication problems within diverse boards of directors. Fourth, mandatory reforms may exacerbate the issue of token female directors, because quota laws force organizations to hire women to the board of directors simply by virtue of their gender, and consequently they may be less well qualified (Choudhury, 2015; Smith, 2018). Fifth, mandatory reforms may promote the practice of multiple directorships for existing women directors due to the lack of availability of qualified women. This particular

\footnotetext{
${ }^{1}$ For more details see Choudhury (2015).

2 https://www.womenonboards.net
} 
argument is supported by the findings of Seierstad and Opsahl (2011) that Norwegian mandatory board diversity reforms has increased neither the percentage of female directors nor the number of female board chairs. Although the number of women holding multiple directorships has increased significantly - Norway's so-called 'golden skirts' - a few women have become more prominent and powerful as a result of the quota law. Conversely, Dale-Olsen et al. (2013) reported that the Norwegian reform was successful from purely a representational perspective. Finally, it is implausible to suppose that the desired level of board gender diversity can be achieved without implementing mandatory reforms, such as those introduced by Norway (Choudhury, 2015).

Our paper adds substantially to the discussion on the arguments for and against mandatory and voluntary board gender requirement by investigating whether quota provides a simple solution to the issue of gender balance on corporate boards or, by breaking the glass ceiling, helps female board (audit committee) members to assert their monitoring skills, reducing the need of assurance provided by external auditors and lowering audit fees.

\section{LITERATURE REVIEW AND HYPOTHESIS DEVELOPMENT}

\subsection{Board Gender Diversity and Audit Fees}

Recently, the debate among scholars in corporate finance and accounting has focused on the impact of gender diversity on board proceedings. These studies highlight that gender differences among directors and managers can be explained by differences in their communication skills, decision-making style, level of overconfidence, risk tolerance, diligence, and monitoring intensity (Abbott, Parker, \& Presley, 2012; Adams \& Ferreira, 2009; Bennouri et al., 2018; Gul et al., 2011; Gull et al., 2018; Gyapong et al., 2016; Harjoto et al., 2015; Huang \& Kisgen, 2013; Huang et al., 2014; Ittonen et al., 2010; Schubert, 2006). The ability to communicate effectively is an important skill for performing well in key managerial positions. There is substantial evidence that women have better communication skills and outperform men in jobs that require communication with various people (Schubert, 2006). Moreover, female directors are likely to reduce information asymmetry by collecting voluntary information from managers and sharing it with the board (Gul, Fung, \& Jaggi, 2009). Another school of thought holds that women, in comparison to men, take ethical considerations more into account when making decisions (Bernardi \& Arnold, 1997; Cohen, Pant, \& Sharp, 1998; Gyapong et al., 2016). Consequently, female board members may prompt a greater demand for audit (Lai et al, 2017), especially in situations characterized by ethical dilemmas, in order to protect personal and organizational reputations and to avoid potential law suits (Fama \& Jensen, 1983; Gilson, 1990). Together, these arguments suggest that women are likely to strengthen the monitoring function of the board.

A large body of literature confirms that women are more conservative and risk-averse than men (Byrnes et al., 1999; Jianakoplos \& Bernasek, 1998; Powell \& Ansic, 1997). According to Schubert (2006) and Watson and McNaughton (2007), women prefer to guard against losses by not taking extreme risks. Additionally, as highlighted by Fondas and Sassalos (2000), women have higher expectations regarding their responsibilities as directors, which may lead them to perform well. Second, female directors tend to be better prepared for board meetings than their male colleagues (Huse \& Solberg, 2006). Gender diversity is therefore likely to improve board behavior and efficiency. Another argument in support of gender diversity might be that, due to the glass ceiling effect, women need to exhibit a higher level of competence than men in order to reach key managerial and board positions (Eagly \& Carli, 2003). Consequently, female representation may increase the proficiency of corporate boards because female directors are highly diligent and competent.

With regard to the external audit process, because of women's greater accounting conservatism and more risk-averse behavior compared to men, auditors may perceive firms 
with gender diverse boards as being less likely to make financial misstatements. Auditors may therefore be prepared to limit the scope of their audit, leading to a lower audit fee. This argument is corroborated by the study by Ittonen et al. (2010), who report that gender-diverse audit committees tend to pay less for audit services. It may thus be argued that gender diversity enriches the monitoring and oversight function of the board. The conservatism and riskaversion of female board members may also have consequences for the credibility of the financial reporting process. According to the findings of a recent study by García-Sánchez, Martínez-Ferrero and García-Meca (2017), the presence of women on the board of directors is instrumental in promoting accounting conservatism and producing higher quality earnings reports. Female directors are known for their favorable impact on the quality of financial reporting (Abbott et al., 2012; Barua, Davidson, Rama, \& Thiruvadi, 2010; Srinidhi, Gul, \& Tsui, 2011), which may reduce the need for assurance provided by external auditors.

With regard to quota reforms, some critics of mandatory board gender diversity argue that quotas may promote the practice of tokenism by appointing unqualified women to the board of directors just because of gender (Choudhury, 2015; Smith, 2018) that may deteriorate the quality of monitoring by the board. These scholars suspect that firms may misuse mandatory board gender diversity reforms by appointing token female directors. Support to this argument is provided by Bolshaw (2011), who report that several wives of leading politicians and controlling shareholders were appointed to the boards of largest French firms after enactment of board gender quotas. Such appointments are classic cases of token female directors and are likely to affect adversely the monitoring function of the board. In line with this conjecture, we argue that gender-diverse boards may not demand higher audit effort from external auditors due to the less monitoring tendency of token female directors. Conversely, it may be the case that external auditors expand the scope of audit task by realizing the fact that gender-diverse boards are less likely to monitor management strictly due to the presence of token female directors especially after implementation of board gender quotas in France.

The above arguments imply that there may be either a positive or a negative relationship between the proportion of female directors and audit fees. Therefore, we propose the following alternative hypothesis.

H1a: Board gender diversity is positively associated with audit fees.

H1b: Board gender diversity is negatively associated with audit fees.

\subsection{Appointment of Women as Independent Directors and Audit Fees}

Accounting studies examining the effect of board structure demonstrate that board independence is associated with greater disclosure, lower earnings management, and lower audit risks (Bedard \& Johnstone 2004; Dechow, Sloan, \& Sweeney, 1996; Gul \& Leung 2004). Boards with more independent directors monitor managers intensely, thereby improving the financial reporting quality of their firms (Klein 2002; Carcello et al. 2006). The demand for higher audit effort from external auditors is another mechanism adopted by independent directors for ensuring the quality of financial information, (Carcello et al., 2002; Lai et al., 2017).

Prior research documents that women tend to exhibit a higher level of independence than their male counterparts. For example, Adams and Ferreira (2009) argue that women do not belong to the "old boys' club," and are therefore expected to challenge the opinions of their colleagues, encourage discussion of sensitive issues, and provide concrete evidence to defend their arguments. They are very much expected to exhibit activism and an independent approach in board proceedings (Adams \& Ferreira, 2009). In addition to monitoring skills, female directors have higher ethical standards, are more risk averse, exhibit less opportunistic behavior, want to avoid the risk of litigation, and are highly concerned about personal and organizational reputation (Krishnan \& Parsons, 2008; Powell \& Ansic, 1997; Srinidhi et al., 2011). Support for this conjecture is offered by Lai et al. (2017), who report that gender-diverse boards appoint 
industry-specialist auditors and demand higher audit effort, resulting in higher audit fees. Their doing so might be due to women's greater concern for high quality audit information, risk oversight, and control mechanisms (Aldamen, Hollindale, \& Ziegelmayer, 2018). In line with these studies, female independent directors may demand higher audit effort to ensure the quality of financial information and to protect their personal and organizational reputation.

Another conjecture is that the presence of women on boards is associated with superior quality financial information. Support for this suggestion is provided by Abbott et al. (2012), who find that boards with at least one woman are less likely to revise their financial statements. Consistently, Arun, Almahrog, and Aribi (2015) argue that managers are less likely to "massage" earnings in the presence of female independent directors. Likewise, the presence of female independent directors on audit committees is positively associated with the transparency of financial information (Pucheta-Martinez et al., 2016). Bearing in mind the effective monitoring skills and favorable impact of female independent directors on the quality of financial information (Abbott et al., 2012; Adams \& Ferreira, 2009; Barua et al., 2010), an alternative explanation might be that the appointment of women as independent directors reduces the level of audit risk and the need for assurance provided by external auditors. This would result in less need for substantive external control, thus lowering audit fees.

Consequently, we posit the following alternative hypothesis:

H2a: The proportion of female independent directors is positively associated with audit fees.

H2b: The proportion of female independent directors is negatively associated with audit fees.

\subsection{Gender-Diverse Audit Committees and Audit Fees}

As a part of corporate governance system, audit committees play a key role in ensuring the quality of financial information. Various studies have shown that audit committee characteristics may affect audit committee effectiveness. The relation between audit committee characteristics and audit fees has been investigated by several scholars (Abbott, Parker, Peters, \& Raghunandan, 2003; Carcello et al., 2002; Harjoto et al., 2015; Ittonen et al., 2010; Lai et al., 2017). These studies show that audit committee characteristics such as size, independence, expertise, meeting activity and gender diversity are important determinants of audit fees.

Audit committees serve as an interface between external auditors and the management of the client firm (Compernolle, 2018; Klein, 2002; Turley \& Zaman, 2004). Similarly, an audit committee can increase the independence level of external auditors by providing them support in the event of any conflict with the management (Compernolle, 2018; Ittonen et al., 2010; Turley \& Zaman, 2004). In this regard, gender-diverse audit committees can facilitate the exchange of information among external auditors and internal management as a result of their superior communication skills. Adams and Ferreira (2009) suggest that women are more likely than their male counterparts to serve on audit committees because of their better monitoring skills. Audit committees are also responsible for overseeing the financial reporting process, including internal audit and control systems and the external audit function. Audit committee members suffer costs to their reputation when they fail to discharge monitoring duties effectively. Directors with a reputation for being effective (ineffective) monitors are rewarded (punished) with increases (decreases) in the number of directorships held (Gilson, 1990). Furthermore, audit committee members are liable to experience increased turnover when their companies issue accounting restatements (Srinivasan, 2005).

Consistently with this suggestion, we argue that gender-diverse audit committees will display a greater tendency to be risk averse due to the reluctance of women to take risks. Thus female audit committee members will prefer to have greater assurance in order to protect their reputation as monitoring experts. Assurance can be obtained in two alternative ways. First, gender-diverse audit committees may demand higher audit effort from external auditors (e.g., longer hours and/or a greater proportion of experienced auditors assigned to the audit), leading to higher audit fees. This view is consistent with the demand-side argument. Support for this 
argument is provided by Lai et al. (2017), who find that gender-diverse audit committees are likely to demand greater audit effort from external auditors. Following a similar line of research, Aldamen et al. (2018) confirm a positive relation between the presence of women on audit committees and the demand for greater audit effort. Therefore, the presence of women on an audit committee is likely to be associated with higher audit fees.

Gender-diverse audit committees can achieve greater assurance by strict monitoring of management in order to ensure the quality of internal control systems and of the financial reporting process. In this regard, Srinidhi et al. (2011) suggest that firms with gender-diverse audit committees have higher earnings and better reporting, which in turn enhance the confidence of external auditors in the firms' financial statements. Pucheta-Martinez et al. (2016) find that the proportion of female directors, female independent directors on audit committees and audit committees chaired by women is correlated with the probability of transparency in financial reporting, by disclosing audit reports with uncertainties and possible scope limitation. A recent study conducted by Gull et al. (2018) in the French context shows that the presence of women on audit committees is negatively associated with earnings management. In line with the evidence provided by these studies and the supply-side perspective, we argue that the presence of women on audit committees may affect auditors' assessment of the internal control system by decreasing control risk, potential audit effort and audit fees. This argument is confirmed by the findings of two relevant studies (Harjoto et al., 2015; Ittonen et al., 2010).

Based on these arguments, we formulate the following alternative hypothesis:

H3a: The appointment of women to audit committees is positively associated with audit fees. H3b: The appointment of women to audit committees is negatively associated with audit fees.

\subsection{The Moderating Role of the Gender Quota Law}

As mentioned earlier, the French gender quota law was enacted on 13 January 2011. As a result, the number and the proportion of women on boards are increasing, though not without raising questions about the consequences of such developments on the efficiency of the board's decision-making. While empirical results on the relationship between the gender quota for female directors and firm performance are mixed (Smith, 2018), there is a consensus that boards (audit committees) with more female members are more likely to be tougher monitors of company executives. If female directors faced many constraints and often serve as tokenism due to their minority status (e.g., Erkut et al., 2008), we should expect that gender quota law will give female directors more opportunities to assert their monitoring skills and will positively impact the board's decision-making process. However, it is notable that French gender quota legislation does not specify either the role played by female directors on the board nor the position that they occupy. To our knowledge, there is no empirical evidence to support the moderating role of the gender quota law in the relationship between board (audit committee) gender diversity and audit fees. Subject to the confirmation of H1, H2 and H3, we test the following hypothesis:

H4: If an association exists between board (audit committee) gender diversity and audit efforts, the gender quota law will strengthen the extent of that association.

\section{RESEARCH METHODOLOGY}

\subsection{Data and Sample}

To compose our sample, we initially considered the largest French firms listed in the SBF 120 index. In this study, we utilize annual data over a period of 16 years from 2002 to 2017 . We start our sample period from 2002, as audit fee data was not available before the introduction 
of the French Financial Security Law. ${ }^{3}$ From this initial population, we eliminated financial, real estate, and foreign companies, as well as companies with missing data. After this screening, our final sample consists of 97 firms and an unbalanced panel sample totaling 1488 firm-year observations. We used Orbis (Bureau Van Dijk) ${ }^{4}$ to collect accounting and financial information. All information on audit fees, non-audit fees, governance structure, ownership structure, female directors, and their appointment as independent directors or audit committee members was compiled manually from annual reports and registration documents available on the French Financial Markets Authority (Autorité des Marchés Financiers) website ${ }^{5}$ or on the websites of individual companies.

\subsection{Model and Variables}

The relationship between female directorship and audit fees may be tainted because of some observable or unobservable characteristics that affect both gender diversity and audit fees. We therefore consider both female directorships and audit fees as endogenous variables. It might be possible that the impact of board gender diversity is due to some firm-specific variables affecting both the appointment of female directors and audit fees simultaneously, thereby leading to biased results due to a potential endogeneity problem. To address this issue, we first control for firm-specific variables that may influence the appointment of female directors and audit fees by performing Propensity Score Matching (PSM) between firms with at least one female director and the subsample of firms with only male directors. We follow Blundell and Bond (1998) and use the two-step system GMM approach to test the dynamic relationship between gender-diverse boards and audit fees. The system GMM produces more reliable results by controlling for simultaneity and omitted variable biases. Additionally, static audit fee models invariably omit an important dynamic dimension of audit pricing behavior (Kacer, Peel, Peel, $\&$ Wilson, 2018). To address the consistency of the GMM estimator, we use Arellano-Bond (1991) auto-correlation tests to detect dynamic specifications of the endogenous and dependent variables. According to Roodman (2009), the system GMM model performs better with only first-order serially correlated processes. The system GMM approach allows to estimate the relationship between female directorship and audit fees in both levels and first differences. The level equation presents audit fees as a function of its past values (lagged values), observable firm characteristics, and the error term including a fixed effect component. The difference equation presents year-to-year differences as instruments in the level equation. Two standards specification tests are carried out to strengthen the choice of the system GMM estimation methodology. The first is the Sargan test for over-identification. The second is the Hansen test of exogeneity of the instruments.

We then test our research hypotheses using the regression model given in Equation (1). Following previous studies (e.g., Carcello et al., 2002; Huang et al., 2014; Ittonen et al., 2010; Kacer et al., 2018; Lai et al., 2017; Peel \& Makepeace, 2012), we use the natural logarithm of audit fees as the dependent variable in order to study the relationship between board gender diversity and audit fees. We also consider governance, ownership, and other control variables that may influence both gender diversity and audit fees.

$$
\begin{aligned}
& A U D_{-} F E E_{i, t}=\alpha_{0}+\alpha_{1} L a g \text { AUD_FEE } E_{i, t}+\alpha_{2} F E M_{-} B D_{i, t}+\alpha_{3} C O R P O R A T E_{-} G O V_{i, t} \\
& +\alpha_{4} \operatorname{CONTROL}_{i, t}+\alpha_{5} \text { INDUSTRY }_{F E}+\alpha_{6} Y E A R_{F E}+\varepsilon_{i, t}
\end{aligned}
$$

\footnotetext{
${ }^{3}$ The French Financial Security Law of 2003 made it mandatory for companies to disclose the fees paid to their auditors. However, in compliance with the European Commission recommendations of May 2002 many firms had already started publishing audit fee data on a voluntary basis.

${ }^{4}$ Orbis BvD - Bureau Van Dijk. https://www.bvdinfo.com/

${ }^{5}$ https://www.amf-france.org/
} 
where $\varepsilon_{\text {it }}$ is the error term and the subscripts $i$ and $t$ stand for firm and year, respectively. $A U D \_F E E$ is the natural logarithm of audit fees. Lag AUD_FEE is the lagged value of audit fees. FEM_BD is the proxy for board gender diversity. First, we follow Al-Shaer and Zaman (2016) by examining a range of measures of gender diversity: the proportion of female directors (PRFEM_BD), the number of female directors $\left(N B F E M_{-} B D\right)$ and two indices of gender diversity: the Shannon index $\left(S H A N \_B D\right)$ and the Blau index $\left(B L A U \_B D\right) .{ }^{6}$ Following Lai et al. (2017), we also consider the position of female directors on the board so as to distinguish between female insider directors who are only on the board and those appointed as independent and audit committee members. ${ }^{7}$ This analysis serves to show whether female directors exhibit intrinsically different skills according to their position on the board. We then measure the proportion of female insider directors in the total number of board directors (PRFEM_INS), the proportion of female non-executive independent directors in the total number of board directors (PRFEM_IND) and the proportion of female audit committee members on the audit committee (PRFEM_ADC).

CORPORATE_GOV is a vector of the corporate governance variables that we consider in this study (BD_SIZE, BD_IND, BD_MEET, ADC_SIZE, ADC_IND, ADC_MEET, DUAL, CEO_TEN, FEM_CEO, FAM_OWN, and INST_OWN). In the same way, CONTROL is a vector of control variables $\left(B I G, A U D \_T E N, N O N A U D \_F E E, L E V, T O B I N, L O S S, R \& D\right.$, FOR_ASSETS, BETA, CROSS, REC\&INV, and F_SIZE). Following previous studies, we control for variables expected to affect audit fees. Board size (BD_SIZE) is likely to be positively associated with audit fees (Huang et al., 2014). Boards with independent directors $\left(B D \_I N D\right)$ are more concerned about their reputation and demand incremental audit effort (Carcello et al., 2002; Zaman et al., 2011). Similarly, more diligent boards (BD_MEET) seek higher levels of transparency by demanding a comprehensive external audit (Carcello et al., 2002; Zaman et al., 2011). Audit committee size (ADC_SIZE), audit committee independence $\left(A D C_{-} I N D\right)$ and the number of audit committee meetings (ADC_MEET) are expected to lead to higher audit fees (Krishnan \& Visvanathan, 2009; Vafeas \& Waegelein, 2007; Zaman et al., 2011). Consistently with the findings of Huang et al. (2014), firms with female CEOs (FEM_CEO) and CEO duality (DUAL) are likely to be positively associated with audit fees. Furthermore, long tenure (CEO_TEN) is another indication of CEO power and the CEO's influence on organizational decisions. It is therefore interesting to study the influence of CEO tenure on audit fees. Ownership structure may have a significant impact on audit fees (Chan, Ezzamel, \& Gwilliam 1993; Mitra et al., 2007; Srinidhi, He, \& Firth, 2014; Barroso et al., 2016). To study the effect of ownership structure, we consider both family (FAM_OWN) and institutional ownership (INST_OWN). Because they are going to be on the board of directors, family and institutional shareholders may have full access to private information and are less prone to use auditing services that may result in lower audit fees (Barroso et al., 2016). Accordingly, we expect both FAM_OWN and INST_OWN to be negatively associated with demand for audit effort, measured by audit fees.

Consistently with the research of Audousset-Coulier (2015), we anticipate a positive relationship between non-audit fees (NONAUD_FEE) and audit fees $(A F)$. For auditor tenure $\left(A U D \_T E N\right)$, we make no directional prediction because it may be positively or negatively associated with audit fees (Lai et al., 2017), depending on client-related factors. For example,

\footnotetext{
${ }^{6}$ The Shannon diversity index is calculated as $-\sum_{i=1}^{n} \mathrm{P}_{\mathrm{i}} \ln \left(\mathrm{P}_{\mathrm{i}}\right)$ where $\mathrm{P}_{\mathrm{i}}$ is the percentage of board members in each category (two: male/female) and $\mathrm{n}$ is the total number of board members. The Blau diversity index is measured as $1-\sum_{i=1}^{n} \mathrm{P}_{i}^{2}$ where $\mathrm{P}_{\mathrm{i}}$ is the percentage of board members in each category (two: male/female) and $\mathrm{n}$ is the total number of board members.

${ }^{7}$ The concept of director independence in France is not far from Anglo-Saxon practices. The following definition is provided in the MEDEF-AFEP report of July 1999: "A director is independent of the corporation's management when he or she has no relationship of any kind whatsoever with the corporation or its group which might risk coloring his or her judgment". Accordingly, current executives, former and retired executives and persons who are related to the founding family or to executive directors are considered as insider directors.
} 
the auditor may have an in-depth (lower) understanding of an established (new) client's accounts. Additionally, firms audited by Big 4 auditors $(B I G)$ pay higher audit fees (Chan et al., 1993; Huang et al., 2014; Peel \& Makepeace, 2012; Zaman et al., 2011; Kacer et al., 2018) and, due to the superior quality of audit services provided, reinforce their competitive advantage over non-Big 4 auditors through audit pricing (Zhang, Xu, Tong, \& Ye, 2018). Audit fees will therefore be higher for firms audited by Big 4 audit firms. Audit planning and risk assessment are two major factors defining audit fees. Firms with a higher level of risk require more audit effort, resulting in higher audit fees. Similarly, firms that have a higher level of leverage $(L E V)$ or report a net loss $(L O S S)$ in the preceding year may reveal a higher level of risk and require incremental audit effort (Carcello et al., 2002; Huang et al., 2014; Lai et al., 2017; Zaman et al., 2011). We consider Tobin's Q (TOBIN) to control for financial performance. Financially sound firms are perceived as being less risky. Thus we expect a negative association between Tobin's $\mathrm{Q}$ and audit fees. We also expect a positive link between research and development expenditure $(R \& D)$ and audit fees. Firms with foreign operations (FOR_ASSETS) are more complex and require greater audit effort (Lai et al., 2017). Similarly, audit fees will be higher for cross-listed firms $(C R O S S)$. In line with the risk assessment argument, a positive relationship is expected between the levels of market risk (BETA) and audit fees. Firms with higher levels of receivables and inventories $(R E C \& I N V)$ are more complicated and require greater audit effort from external auditors, resulting in higher audit fees. Finally, large firms ( $\left.F_{-} S I Z E\right)$ undertake more transactions and auditors require more time to audit their financial records. For this reason, large firms pay higher audit fees (Carcello et al., 2002; Chan et al., 1993; Zaman et al., 2011). We finally control for the quota law implemented in 2012 (QUOTA), which impose quotas for the gender balance of company boards. This variable equals 1 after the implementation of the quota law reform in 2012 and 0 otherwise.

\section{DATA ANALYSIS AND RESULTS}

\subsection{Descriptive Statistics}

Table 1 presents descriptive statistics for the entire sample. In our sample, the mean amount of total audit fees paid by client firms is $€ 6,939 \mathrm{~K}$. Audit fees ranges from $€ 45.86 \mathrm{~K}$ to a maximum of $€ 53.4 \mathrm{M}$, while the amount of audit fees paid by half (median) of the sampled firms is $€ 3672 \mathrm{~K}$, indicating broad disparity in the amount paid for audit fees. The mean value of nonaudit fees paid by French firms is $€ 586.85 \mathrm{~K}$ with a maximum of $€ 35.51 \mathrm{M}$. With regard to board gender diversity, our results show that French firms appoint about two female directors (NBFEM_BD) and the mean proportion of female directors (PRFEM_BD) is $18.40 \%$. For the other two proxies for board gender diversity, we report a mean of 0.253 for the Shannon index and a mean of 0.384 for the Blau index. The means of these two proxies for board gender diversity are slightly higher than those reported by Al-Shaer and Zaman (2016) for a sample of 333 UK companies listed in 2012 (0.218 and 0.348, respectively). The mean value of the proportion of female independent directors (PRFEM_IND) is $10.24 \%$, and $19.26 \%$ of audit committee members are female (PRFEM_ADC). On average (mean), sample firm-years are audited by at least one BIG auditor (1.40); while the $25^{\text {th }}$ and the $50^{\text {th }}$ percentiles of Big auditors are 1. The mean auditor tenure (AUD_TEN) is about 12 years, with a maximum of 34 years. The average (mean) board size (BD_SIZE) of our sample firms is about 12 members and $47.17 \%$ of directors are independent (BD_IND). In addition, our sample firms' boards arrange 7.14 meetings $\left(B D \_M E E T\right)$ per year, with a maximum of 30 meetings per year. ${ }^{8}$ Table 1 shows that audit committees are composed of three to four members on average (ADC_SIZE) with an average independence rate $\left(A D C_{-} I N D\right)$ of $68.82 \%$. The average number of meetings

\footnotetext{
${ }^{8}$ Based on a sample of non-financial French listed companies during the period 2004-2008, Maraghni and Nekhili (2014) also report significant differences in the number of annual board meetings, which ranges from 2 to 29.
} 
$\left(A D C \_M E E T\right)$ is 4.65 . The range of frequencies observed in the sample extends from one single meeting to 19 meetings, reflecting significant differences in audit committee diligence. ${ }^{9}$ $\mathrm{CEO} /$ Chairperson duality $(D U A L)$ is $58.14 \%$ and mean value of CEO tenure (CEO_TEN) is almost 8 years. Only $1.81 \%$ of firm-year observations have female CEOs (FEM_CEO). With regard to ownership structure, the results in Table 1 show that the mean percentage of family and institutional ownership is 25.91 and 25.82, respectively. Regarding family ownership, Nekhili, Nagati, Chitioui and Rebolledo (2017) report similar results for the largest French companies of the $120 \mathrm{SBF}$ index between 2001 and 2010 (26.67\%). ${ }^{10}$ The mean (median) of leverage $(L E V)$ is $24.28(14.61 \%)$. Tobin's Q is higher than unity (1.21). On average, $13.14 \%$ of firms report a loss in the preceding year. Research and development $(R \& D)$ expenditure is $2.77 \%$ of total sales on average. The mean value of assets in other countries (FOR_ASSETS) is $20.13 \%$. The mean (median) value of $R E C \& I N V$ is $13.62(16.33 \%)$, whereas on average, the percentage of cross-listing is 24.46. Finally, $F \_S I Z E$ is 19.07 billion euros.

\section{[Please insert Table 1 here]}

Table 2 confirms the propensity for French companies to have more female directors. Clearly, the percentage of female directors (Column 2) grew significantly over the years. This trend is more pronounced from 2012 because of the enactment of the quota law in 2011. Interestingly, the trend is also observed for female insider directors (Column 3) as well as for female independent directors (Column 4) and female audit committee members (Column 6). Interestingly too, the trends of female insider directors and female independent directors are inversely proportional. More specifically, since the enactment of the quota law in 2011, female insider directors give way to female independent directors, giving evidence to the preference of French firms for more active monitoring role of female directors in a mandatory context. Similarly, over the years, the increase in the proportion of female audit committee members (Column 6) changes in the same way as the increase in the proportion of female board directors (Column 2). At the same time, the evolution of board size (Column 1) and audit committee size (Column 5) remains quasi-steady and does not change to a great extent over time, albeit significantly. These findings suggest that the appointment of new female directors to the board (audit committee) did not occur by increasing the size of the board size (audit committee) but principally by replacing male directors. To assess statistically the occurrence of trends for female directorship, we carried out a Mann-Kendall non-parametric test for trend analysis. The null hypothesis of no trend over time is rejected for all variables.

\section{[Please insert Table 2 here]}

The results of the Pearson correlation analysis and variance inflation factors (VIF) of all variables considered in this study are given in Table 3. The correlation and VI factors of all variables are within the allowed limits. Thus our sample does not suffer from multicollinearity issues that could influence the results. It is, however, noteworthy that female representation variables are positively and significantly correlated with each other.

\section{[Please insert Table 3 here]}

\footnotetext{
${ }^{9}$ Maraghni and Nekhili (2014) argue that, despite the fact that audit committee meetings should be aligned with the accounting cycle, many French audit committees do not meet more frequently than required by their charter.

${ }^{10}$ For a larger sample of French listed companies including smaller firms, the proportion of family ownership is significantly higher. Nekhili et al. (2018) report a proportion of family ownership of $36.84 \%$ for French companies of the CAC All-Shares index listed on Euronext Paris (whose annual trading volume exceeds 5\% of their share capital) over the period 2001-2010, highlighting the fact that the French stock market is dominated by familycontrolled firms.
} 


\subsection{Propensity Score Matching}

The potential impact of gender diversity may arise because of firm-specific variables that concurrently affect both the appointment of female directors and audit fees. It would not, therefore, be a judicious choice to analyze all firms directly, neglecting firm-specific differences. We utilize the propensity score matching (PSM) technique to control for firm-level characteristics, as developed by (Rosenbaum \& Rubin, 1983). This approach is being increasingly used in accounting research to evaluate treatment effects (Peel \& Makepeace, 2012). We match firms with a high proportion of female directors to a set of control firms with a low proportion of female directors whose characteristics are approximately similar (the closest forecast propensity score) to firms with gender-diverse boards. Accordingly, we derive a dummy variable to represent a high proportion of female directors, which takes the value 1 for firm-year observations with a proportion of female directors greater than the median $(15.38 \%)$, and 0 otherwise. We apply a condition on the highest propensity caliper to rule out the likelihood of poor matching by adjusting caliper distance to 0.01 without replacement. ${ }^{11} \mathrm{By}$ doing so, we have a matched sample comprising 914 observations: 457 treatment and 457 control cases. In Table 4, the differences between control variables decrease in magnitude and are not significant in comparison to the unmatched sample. Finally, we have a sample comprising firms with similar firm-specific characteristics.

\section{[Please insert Table 4 here]}

\subsection{Test of H1a and H1b}

To test $\mathrm{H} 1 \mathrm{a}$ and $\mathrm{H} 2 \mathrm{a}$, we use four different proxies of board gender diversity (i.e., the proportion of female directors (PRFEM_BD), the number of female directors (NBFEM_BD), the Shannon index $\left(S H A N \_B D\right)$ and the Blau index $\left.\left(B L A U \_B D\right)\right)$. Based on the PSM sample, In order to address the different sources of endogeneity, our main estimation approach is the system GMM method suggested by Blundell and Bond (1998). For completeness, Table 5 reports the results of the OLS estimation, the fixed effect estimation, and the system GMM estimation. While the signs of the coefficient of the OLS and system GMM estimations are the same, the significance of some coefficients differs markedly. For our variable of interest (PRFEM_BD), the estimate is higher in significance and magnitude. System GMM reduces the risk of biased estimators caused by the heterogeneity effect, simultaneity and dynamic endogeneity (Bennouri et al., 2018; Kacer et al., 2018; Sila, Gonzalez, \& Hagendorff, 2016; Wintoki, Linck, \& Netter, 2012). Accordingly, our discussion focuses on the results of the system GMM estimations. Table 6 shows the results of the system GMM regression analysis of the other proxies of board gender diversity (i.e., the number of female directors $\left(N B F E M \_B D\right)$, the Shannon index $\left(S H A N \_B D\right)$ and the Blau index $\left.\left(B L A U \_B D\right)\right)$. Results are unchanged from the one observed in Table 5 for the proportion of female directors. ${ }^{12}$

Our findings are consistent with the argument that women are stricter monitors, strengthen internal control systems, produce high quality earnings, and enhance the quality of financial reporting (Abbott et al., 2012; Adams \& Ferreira, 2009; Barua et al., 2010; García-Sánchez et al., 2017; Gull et al., 2018; Srinidhi et al., 2011), thereby reducing the demand for external audit assurance, and de facto the audit fees paid to incumbent auditors. Ittonen et al. (2010) offer an alternative explanation for the negative correlation between gender diversity and audit fees. They argue that auditors may be willing to limit the scope of their audit on account of women's

\footnotetext{
${ }^{11}$ Matching without replacement ensures that a treated case will be matched with only one control observation.

${ }^{12}$ In untabulated results, we find that the impact of each proxy of board gender diversity (i.e., PRFEM_BD, NBFEM_BD, SHAN_BD, and BLAU_BD) on audit fees is not significant for the OLS and the fixed effect estimations. Tables are available upon request.
} 
superior monitoring skills and risk-averse approach, leading to lower audit fees for firms with gender diverse boards. Overall, these results highlight the significant influence of women on the effectiveness and the quality of the board's monitoring, resulting in the reduction of effort and resources dedicated to the audit of financial statements. Thus H1b is confirmed and H1a is rejected.

In line with prior research (Audousset-Coulier, 2015; Carcello et al., 2002; Chan et al., 1993; Huang et al., 2014; Lai et al., 2017), we find that the coefficients of our control variables (NONAUD_FEE, AUDIT_TEN, BD_SIZE, BD_IND, BD_MEET, FOR_ASSETS, REC\&INV, CROSS \& F_SIZE) are significant and in the expected direction. Audit committee size $\left(A D C \_S I Z E\right)$ and audit committee independence (ADC_IND) are more likely to affect negatively and significantly the fees paid to auditors. Audit committee characteristics may reduce the perceived audit risk and, in turn, decrease the fees paid to external auditors (Ittonen et al., 2010). According to our prediction, FAM_OWN, INST_OWN and LOSS are negatively and significantly associated with audit fees. For the remaining variables (BIG, ADC_MEET, DUAL, FEM_CEO, CEO_TEN, LEV, TOBIN \& R\&D), we do not find any significant relationship with audit fees.

\section{[Please insert Tables 5, 6]}

\subsection{Test of $\mathrm{H} 2 \mathrm{a}, \mathrm{H} 2 \mathrm{~b}, \mathrm{H} 3 \mathrm{a}$ and $\mathrm{H} 3 \mathrm{~b}$}

According to $\mathrm{H} 2 \mathrm{a}(\mathrm{H} 2 \mathrm{~b})$ and $\mathrm{H} 3 \mathrm{a}(\mathrm{H} 3 \mathrm{~b})$, we expect female independent directors (PRFEM_IND) and female audit committee members (PRFEM_ADC) to have a positive (negative) relationship with audit fees, since women as independent and as audit committee members enhance the monitoring ability of the board and audit committee, thereby increasing (reducing) the need for assurance provided by external auditors in terms of audit effort. By way of comparison, we also consider the proportion of female insider directors (PRFEM_INS). As in the earlier test, we first use the PSM procedure for each proxy of board (audit committee) gender diversity (i.e., PRFEM_INS, PRFEM_IND and PRFEM_ADC). ${ }^{13}$ For each proxy, we derive a dummy variable to represent a high proportion of female directors (audit committee members), according to its median. Tables 7, 8 and 9 report pre- and post-match pairwise differences of control variables with regard to each matched variable (PRFEM_INS, PRFEM_IND and PRFEM_ADC, respectively). Results show that post-match pairwise differences between treatment and control groups decrease in magnitude with respect to the pre-match sample and become statistically non-significant. Importantly, when we compare firm-year observations with a high proportion of female independent directors to similar firmyear observations with a low proportion of female independent directors via PSM technique, we find that treatment and control groups have an intrinsically significant difference in audit fees (Table 8). This is also the case when we match our sample based on the proportion of female audit committee members (Table 9). These results indicate that differences in audit fees are not solely due to the overlaps between the proportion of female directors and the firms' other characteristics.

\section{[Please insert Tables $7,8 \& 9$ here]}

Models in Table 10 include QUOTA as a control variable. In this table, we report the results of the impact of the proportion of female board directors (Model 1), the proportion of female insider directors (Model 2), the proportion of female independent directors (Model 3) and the proportion of female audit committee members (Model 4) on audit fees, respectively. With the

\footnotetext{
${ }^{13}$ As in Lai et al. (2017), we eliminate firm-years observations with all-male audit committees in the matching procedure for gender-diverse audit committees.
} 
exception of Model 3, the effect of the coefficient of the implementation of gender quota law (QUOTA) on audit fees (AUD_FEE) is negative. The regression results of Table 10 indicate that the coefficient estimates for PRFEM_IND (Model 3) and PRFEM_ADC (Model 4) are negative and statistically significant at the $1 \%$ level, thus confirming $\mathrm{H} 2 \mathrm{~b}$ and $\mathrm{H} 3 \mathrm{~b}$ and rejecting $\mathrm{H} 2 \mathrm{a}$ and H3a. Nevertheless, the result of Model 2 in Table 10 shows that the proportion of female insider directors (PRFEM_INS) is likely to influence positively the external audit efforts as measured by audit fees. These results confirm the role played by female independent directors and female audit committee members in improving board monitoring effectiveness. Female independent directors and female audit committee members may considerably reduce the incidence of financial reporting problems and enhance the integrity of internal control and internal audit procedures, resulting in a decrease of the auditor's assessment of risk and in lowering audit fees paid to incumbent auditors (Harjoto et al., 2015; Ittonen et al., 2010).

[Please insert Table 10 here]

\subsection{Test of $\mathrm{H4}$}

H4 states that the gender quota law may strengthen the relationship between board (audit committee) gender diversity and audit fees. We test this proposition by using a difference-indifference technique. We introduce a pre- and post-quota control variable (QUOTA) that equals 1 after the adoption of the quota law reform in 2011, and 0 otherwise. We then estimate Equation 2 on the PSM sample, which includes the main effects of each treatment variable (i.e., PRFEM_BD, PRFEM_INS, PRFEM_IND and PRFEM_ADC) and QUOTA on audit fees (AUD_FEE).

$$
\begin{aligned}
\text { AUD_FEE } E_{i, t}= & \alpha_{0}+\alpha_{1} \operatorname{Lag} \text { AUD_FEE } E_{i, t}+\alpha_{2} \text { TREATMENT } T_{i, t}+\alpha_{3} \text { QUOT }_{t} \\
& +\alpha_{4}\left(\text { TREATMENT } T_{i, t} * Q U O T A_{t}\right)+\alpha_{5} \text { CORPORATE_GOV }_{i, t} \\
& +\alpha_{6} \text { CONTROL L L }_{i, t}+\varepsilon_{i, t}
\end{aligned}
$$

where TREATMENT takes the value of PRFEM_BD, PRFEM_INS, PRFEM_IND and PRFEM_ADC, respectively. $\varepsilon$ is the error term and the subscripts $i$ and $t$ stand for firm and year, respectively. Table 11 reports the result of the system GMM estimation with four different specifications of Equation (2) (Models 1,2, $3 \&$ 4). Since we are measuring the marginal effect of gender board (audit committee) diversity on audit fees (AUD_FEE) in the post-quota period, the test of importance here is the joint test of the sum of the coefficients on each treatment variable and the interaction term (TREATMENT*QUOTA). The results of Table 11 show that the joint coefficient $\left(\alpha_{2}+\alpha_{4}\right)$ is negative and significant for the proportion of female directors (PRFEM_BD), for the proportion of independent directors (PRFEM_IND), and for the proportion of female audit committee members (PRFEM_ADC). This finding suggests that the negative relation between the presence of women as independent (Model 3) and as audit committee members (Model 4), on the one side, and audit fees, on the other side, gets stronger after the implementation of the gender quota law. Nevertheless, the joint coefficient for female insider directors (PRFEM_INS) is positive and significant. It follows that $\mathrm{H} 4$ is partially confirmed. Regarding audit fees paid to incumbent auditors, the effectiveness of the gender quota law, while breaking the glass ceiling, stems from boosting the appointment of women as independent directors and as audit committee members and not from increasing the number and the proportion of female insider directors. These results give support to French companies in their decision, since the implementation of the gender quota law in 2012, to privilege the new appointment of female as independent directors and as audit committee members rather than their appointment as insider directors (Table 2). Our findings are inconsistent with Choudhury (2015) and Smith (2018) that mandatory reforms may force organizations to hire less qualified female directors and may promote female tokenism on boards. 
[Please insert Table 11 here]

\subsection{Supplementary Analysis}

\section{The firm size effect}

We follow Aldamen et al. (2018) in order to investigate the interplay of female directorships (audit committee memberships) and firm size. To this end, we derive a new dummy variable (SIZE_DUM), which takes the value 1 for larger firms with total assets greater than the median and 0 otherwise. For each treatment variable (i.e., PRFEM_BD, PRFEM_INS, PRFEM_IND and PRFEM_ADC), we introduce its interaction term with SIZE_DUM in the model. Table 12 shows that the impact of SIZE_DUM on audit fees is positive and significant, suggesting that the complex nature of large firms leads to relatively higher audit fees. With regard to treatment variables related to board diversity (i.e., PRFEM_BD, PRFEM_INS, PRFEM_IND), the interaction term with $S I Z E_{-} D U M$ is strongly negative and significant. These results indicate that firm size strengthens the negative relationship between the proportion of female (insiders or independent) directors and audit fees. As shown by the joint tests, the marginal effects of appointing female directors (Model 1), female insider directors (Model 2) and female independent directors (Model 3) are also strongly negative and significant. For the treatment variable related to the representation of women on the audit committee (PRFEM_ADC), we do not find, in contrast to Aldamen et al. (2018), a significant relationship between the interaction term (PRFEM_ADC* SIZE_DUM) and audit fees (Model 4). Furthermore, the joint effect is not significantly stronger than the interaction effect. This result may be explained by the fact that the proportion of women on the audit committee does not vary much with firm size. ${ }^{14}$

[Please insert Table 12]

\section{The Impact of Gender Diverse Boards (Audit Committees) on Non-audit Fees}

It is generally accepted that non-audit fees may compromise the independence of auditors (e.g., Ashbaugh, Lafond, \& Mayhew, 2003; DeFond, Raghunandan, \& Subramanyam, 2002; Frankel, Johnson, \& Nelson, 2002). Accordingly, it is interesting to examine whether women on the board (audit committee) reinforces trust in auditors' independence by lowering non-audit fees. We test these predictions by replacing audit fees (AUDIT_FEE) in Equation 2 by non-audit fees (NAUDIT_FEE). In Table 13, the level of non-audit fees is affected negatively by each treatment variable (i.e., PRFEM_BD, PRFEM_INS, PRFEM_IND and PRFEM_ADC). Nevertheless, the implementation of the gender quota law is likely to alter these relationships. The results provided in Table 14 show that, after the implementation of the gender quota law, the effect of the proportion of female insider directors (PRFEM_INS*QUOTA) and the effect of the proportion of female audit committee members (PRFEM_ADC*QUOTA) turn to be positive and significant. The negative effect of female independent directors (PRFEM_IND*QUOTA) on non-audit fees is, however, strengthened after the implementation of the gender quota law $\left(\alpha_{4}=-2.758 ; \mathrm{t}=-2.79\right)$. Importantly, the marginal effect of appointing female independent directors after the quota law as provided by the difference-indifference test $($ PRFEM_IND + PRFEM_IND*QUOTA $)$ is strongly negative $\left(\alpha_{2}+\alpha_{4}=-2.370\right)$ and significant $(\mathrm{t}=3.42)$. These results suggest that only female independent directors are more likely to be

\footnotetext{
${ }^{14}$ These results should, however, be treated with caution since our sample consists only of the largest firms in the SBF 120 index.
} 
concerned about the independence of external auditors. ${ }^{15}$

[Please insert Tables $13 \& 14$ here]

\section{The Incremental Effect of Gender Diversity in the Audit Committee}

Following Lai et al. (207), we investigate whether the effects of having female audit committee members on audit fees and non-audit fees are incremental to having female directors on the board only. To this end, we create a new variable PRFEM_BDONLY defined as the proportion of female directors who are only on the board and do not participate in the audit committee compared to total numbers of board directors. We include both the variables PRFEM_ADC and PRFEM_BDONLY in the audit fee (AUD_FEE) and the non-audit fee (NAUD_FEE) models. The results of Table 15 show that both variables are negatively and significantly associated with audit fees. Nevertheless, when consisting of non-audit fees (NAUD_FEE), PRFEM_ADC and PRFEM_BDONLY act in the opposite direction. PRFEM_ADC is negatively and significantly associated with non-audit fees and PRFEM_BDONLY is positively and significantly associated with non-audit fees.

[Please insert Table 15 here]

\section{CONCLUSION}

This paper examines whether gender-diverse boards (audit committees) affect the demand for audit effort, measured by audit fees. Motivated by the documented gender differences in ethics, risk aversion, decision making, and overconfidence, and recent findings in the corporate governance literature, we hypothesize that gender diverse boards may affect the level of fees paid to external auditors for audit services. A recently published study by Lai et al. (2017) discusses the relationship between board gender diversity and audit fees. This study broadens our current knowledge of the role of female directors by examining a French setting, which has a different governance and legal structure in terms of ownership and institutional background than the U.S. (Lai et al., 2017). Along similar lines, Hay et al. (2006) highlight a gap in the existing audit literature and recommend investigating the influence of ownership structure and local institutional factors on audit fees. During the two last decades, board gender diversity reforms have been adopted worldwide, with the aim of increasing female representation on boards of directors. Following the example of Norway, France opted in January 2011 for a hard quota law, meaning that non-complying firms are subject to explicit sanctions. Nevertheless, as well as in the rest of the countries which adopted quota law, this reform does not provide any guidelines as to the roles that should be assigned to female directors. Going forward, we then consider the influence of gender quota legislation. Doing so, allows us to provide further insights into the relationship between gender diverse boards (audit committees) and audit fees in voluntary and mandatory contexts.

We use the system GMM estimation approach on a matched sample of French listed firms between the years 2002 and 2017 to examine the relation between gender diverse boards and audit fees, by highlighting the role of gender quota regulation in promoting the efficiency of the board's decision-making. In contrast to the findings reported by Lai et al. (2017), our results provide evidence that gender diverse boards (audit committees) reduce the demand for incremental audit effort due to their superior monitoring skills, resulting in lower audit fees. These results are in line with the supply side argument and underline the role played by female independent directors and female audit committee members in improving board monitoring

\footnotetext{
${ }^{15}$ In a separate test, we consider the proportion of independent female audit committee members compared to the total number of audit committee members. The results are similar to those obtained for female independent board directors.
} 
effectiveness. The appointment of women to the board as independent directors and as audit committee members may therefore decrease the auditor's assessment of risk and reduce audit fees by enhancing the integrity of internal control and internal audit procedures (Harjoto et al., 2015; Ittonen et al., 2010). The enactment of the gender quota law in January 2011 made our focus on France even more interesting by allowing us to study the implications of both voluntary and mandatory board gender-diversity for French firms. In our study, we use the difference-in-difference technique to test whether gender quota law moderates the relationship between board (audit committee) gender diversity and audit fees. Our results show that the advantage of the gender quota law is not related to the increase of the number and the proportion of female directors as a whole, but rather to the appointment of women as independent directors and as audit committee members. These results vindicate French companies which, since the implementation of the gender quota law in 2012, decided to promote the number and the proportion of both female independent directors and female audit committee members and to reduce the number and the proportion of female insider directors. Additionally, we find that the implementation of the gender quota law strengthened the negative relationship between the proportions of female independent directors on board, as well as on audit committee, and the magnitude of non-audit fees. In contrast, the effect of the proportion of female insider directors (female audit committee members) on the non-audit fees turns to be positive and significant after the implementation of the gender quota law. These results provide evidence on the importance of independence for female board (audit committee) directors to assert their monitoring skills and to achieve better audit outcomes.

In spite of its incremental contributions, this study has a number of limitations. We conclude that the lower audit fees for companies with gender-diverse boards are due to the accuracy of their internal control systems and financial reporting process. This conclusion does not rule out other possible interpretations, for example that lower audit fees may result from the ability of female directors to negotiate with external auditors. Further studies are called for to investigate the mechanism by which female directors (audit committees' members) influence audit fees. Audit partners and audit firms' characteristics may have a significant impact on audit fees (Hardies, Breesch, \& Branson, 2015). Likewise, audit firms with higher industry specialization are more likely to earn an audit fee premium. Focusing on the French context, Nekhili, Javed and Chtioui (2018) find that gender, experience, industry expertise, and careers of engagement partners are important determinants of audit fees. In a joint audit setting, Nekhili et al. (2018) argue that the interaction between engagement partners within the joint pair composition should also be considered. Although we control for variables that would affect audit fees, our study is limited by the degree to which audit fee reflect audit effort, because it omits other assurance services that may be purchased by the client organization in separate transactions. Our study is also limited to the case of the largest French firms listed in the SBF 120 stock market index. A potential avenue for future research would be to determine whether our findings are also consistent for smaller firms.

\section{REFERENCES}

Abbott, L. J., Parker, S., \& Peters, G. F. (2004). Audit committee characteristics and restatements. Auditing: A Journal of Practice \& Theory, 23, 69-87.

Abbott, L. J., Parker, S., Peters, G. F., \& Raghunandan, K. (2003). An empirical investigation of audit fees, nonaudit fees, and audit committees. Contemporary Accounting Research, 20, 215-234.

Abbott, L. J., Parker, S., \& Presley, T. J. (2012). Female board presence and the likelihood of financial restatement. Accounting Horizons, 26, 607-629.

Adams, R. B., \& Ferreira, D. (2009). Women in the boardroom and their impact on governance and performance. Journal of Financial Economics, 94, 291-309. 
Aldamen, H., Hollindale, J., \& Ziegelmayer, J. L. (2016). Female audit committee members and their influence on audit fees. Accounting \& Finance, 58, 57-89.

Al-Shaer, H., \& Zaman, M. (2016). Board gender diversity and sustainability reporting quality. Journal of Contemporary Accounting \& Economics, 12, 210-222.

Arnardottir, A. A., \& Sigurjonsson, T. O. (2017). Gender diversity on boards in Iceland: Pathway to gender quota law following a financial crisis. In Gender Diversity in the Boardroom (pp. 75-101). Springer.

Arellano, M., \& Bond, S. (1991). Some tests of specification for panel data: Monte Carlo evidence and an application to employment equations. The Review of Economic Studies, 58, 277-297.

Arun, T. G., Almahrog, Y. E., \& Aribi, Z. A. (2015). Female directors and earnings management: Evidence from UK companies. International Review of Financial Analysis, 39, 137-146.

Ashbaugh, H., Lafond, R., \& Mayhew, B. W. (2003). Do non-audit services compromise auditor independence? Further evidence. The Accounting Review, 78, 611-639.

Audousset-Coulier, S. (2015). Audit fees in a joint audit setting. European Accounting Review, 24, 347-377.

Autorité des Marchés Financiers (Financial Markets Authority). https://www.amf-france.org

Barroso, R., Ben Ali, C., \& Lesage, C. (2018). Blockholders' ownership and audit fees: The impact of the corporate governance model. European Accounting Review, 27, 149-172.

Barua, A., Davidson, L. F., Rama, D. V., \& Thiruvadi, S. (2010). CFO gender and accruals quality. Accounting Horizons, 24, 25-39.

Bedard, J. C., \& Johnstone, K. M. (2004). Earnings manipulation risk, corporate governance risk, and auditors' planning and pricing decisions. The Accounting Review, 79, 277-304.

Bennouri, M., Chtioui, T., Nagati, H., \& Nekhili, M. (2018). Female board directorship and firm performance: What really matters? Journal of Banking \& Finance, 88, 41-52.

Bennouri, M., Nekhili, M., \& Touron, P. (2015). Does auditor reputation "discourage" relatedparty transactions? The French case. Auditing: A Journal of Practice \& Theory, 34, 1-32.

Bernardi, R. A., \& Arnold, D. F. (1997). An examination of moral development within public accounting by gender, staff level, and firm. Contemporary Accounting Research, 14, 653668.

Blue Ribbon Committee (1999). Report and recommendations of the Blue Ribbon Committee on improving the effectiveness of corporate audit committees. New York, NY: New York Stock Exchange and National Association of Securities Dealers.

Blundell, R., \& Bond, S. (1998). Initial conditions and moment restrictions in dynamic panel data models. Journal of Econometrics, 87, 115-143.

Bolshaw, L. (2011). Glass ceilings starting to crack across europe. Financial Times (Dec. 12, 2011).

Bushman, R., Chen, Q., Engel, E., \& Smith, A. (2004). Financial accounting information, organizational complexity and corporate governance systems. Journal of Accounting and Economics, 37, 167-201.

Byrnes, J. P., Miller, D. C., \& Schafer, W. D. (1999). Gender differences in risk taking: A metaanalysis. Psychological Bulletin, 125, 367-383.

Carcello, J. V., Hermanson, D. R., Neal, T. L., \& Riley, R. A. (2002). Board characteristics and audit fees. Contemporary Accounting Research, 19, 365-384.

Carcello, J. V., Hollingsworth, C. W., \& Neal, T. L. (2006). Audit committee financial experts: A closer examination using firm designations. Accounting Horizons, 20, 351-373.

Chan, P., Ezzamel, M., \& Gwilliam, D. (1993). Determinants of audit fees for quoted UK companies. Journal of Business Finance \& Accounting, 20, 765-786.

Chen, Y. M., Moroney, R., \& Houghton, K. (2005). Audit committee composition and the use of an industry specialist audit firm. Accounting \& Finance, 45, 217-239. 
Choudhury, B. (2014). New rationales for women on boards. Oxford Journal of Legal Studies, $34,511-542$.

Choudhury, B. (2015). Gender diversity on boards: Beyond quotas. European Business Law Review, 26, 229-243.

Cohen, J. R., Pant, L. W., \& Sharp, D. J. (1998). The effect of gender and academic discipline diversity on the ethical evaluations, ethical intentions and ethical orientation of potential public accounting recruits. Accounting Horizons, 12, 250-270.

Compernolle, T. (2018). Communication of the external auditor with the audit committee: Managing impressions to deal with multiple accountability relationships. Accounting, Auditing \& Accountability Journal, 31, 900-924.

Dale-Olsen, H., Schøne, P., \& Verner, M. (2013). Diversity among Norwegian boards of directors: Does a quota for women improve firm performance? Feminist Economics, 19, 110-135.

Dechow, P. M., Sloan, R. G., \& Sweeney, A. P. (1996). Causes and consequences of earnings manipulation: An analysis of firms subject to enforcement actions by the SEC. Contemporary Accounting Research, 13, 1-36.

DeFond, M. L., \& Francis, J. R. (2005). Audit research after sarbanes-oxley. Auditing: A Journal of Practice \& Theory, 24, 5-30.

DeFond, M. L., Raghunandan, K., \& Subramanyam, K. R. (2002). Do non-audit service fees impair auditor independence? Evidence from going-concern audit opinions. Journal of Accounting Research, 40, 1247-1274.

Eagly, A. H., \& Carli, L. L. (2003). The female leadership advantage: An evaluation of the evidence. The Leadership Quarterly, 14, 807-834.

Erkut, S., Kramer, V. W., \& Konrad, A. M. (2008). Critical mass: Does the number of women on a corporate board make a difference. In Women on Corporate Boards of Directors, eds. Vinnicombe, S., Singh, V., Burke, R. J., Bilimoria, D., \& Huse, M., 350-66. Cheltenham, UK: Edward Elgar.

Faccio, M., \& Lang, L. H. (2002). The ultimate ownership of Western European corporations. Journal of Financial Economics, 65, 365-395.

Fama, E. F., \& Jensen, M. C. (1983). Separation of ownership and control. The Journal of Law and Economics, 26, 301-325.

Ferrari, G., Ferraro, V., Profeta, P., \& Pronzato, C. (2018). Do board gender quotas matter? Selection, performance and stock market effects. IZA Discussion Paper No. 11462. Available at SSRN: https://ssrn.com/abstract=3170251

Fondas, N., \& Sassalos, S. (2000). A different voice in the boardroom: How the presence of women directors affects board influence over management. Global Focus, 12, 13-22.

Frankel, R. M., Johnson, M. F., \& Nelson, K. K. (2002). The relation between auditors' fees for non-audit services and earnings management. The Accounting Review, 77, 71-105.

Gilson, S. C. (1990). Bankruptcy, boards, banks, and blockholders: Evidence on changes in corporate ownership and control when firms default. Journal of Financial Economics, 27, 355-387.

García-Sánchez, I. M., Martínez-Ferrero, J., \& García-Meca, E. (2017). Gender diversity, financial expertise and its effects on accounting quality. Management Decision, 55, 347382.

Gul, F. A., Fung, S. Y. K., \& Jaggi, B. (2009). Earnings quality: Some evidence on the role of auditor tenure and auditors' industry expertise. Journal of Accounting and Economics, 47, 265-287.

Gul, F. A., \& Leung, S. (2004). Board leadership, outside directors' expertise and voluntary corporate disclosures. Journal of Accounting and Public Policy, 23, 351-379.

Gul, F. A., Srinidhi, B., \& Ng, A. C. (2011). Does board gender diversity improve the informativeness of stock prices? Journal of Accounting and Economics, 51, 314-338. 
Gull, A. A., Nekhili, M., Nagati, H., \& Chtioui, T. (2018). Beyond gender diversity: How specific attributes of female directors affect earnings management. The British Accounting Review, 50, 255-274.

Gyapong, E., Monem, R. M., \& Hu, F. (2016). Do women and ethnic minority directors influence firm value? Evidence from post-apartheid South Africa. Journal of Business Finance \& Accounting, 43, 370-413.

Hardies, K., Breesch, D., \& Branson, J. (2015). The female audit fee premium. Auditing: A Journal of Practice \& Theory, 34, 171-195.

Harjoto, M. A., Laksmana, I., \& Lee, R. (2015). The impact of demographic characteristics of CEOs and directors on audit fees and audit delay. Managerial Auditing Journal, 30, 963 997.

Hay, D. C., Knechel, W. R., \& Wong, N. (2006). Audit fees: A Meta-analysis of the effect of supply and demand attributes. Contemporary Accounting Research, 23, 141-191.

Holst, E., \& Kirsch, A. (2016). Corporate boards of large companies: More momentum needed for gender parity. DIW Economic Bulletin, 6, 13-25.

Huang, J., \& Kisgen, D. J. (2013). Gender and corporate finance: Are male executives overconfident relative to female insiders? Journal of Financial Economics, 108, 822-839.

Huang, T. C., Huang, H. W., \& Lee, C. C. (2014). Corporate executive's gender and audit fees. Managerial Auditing Journal, 29, 527-547.

Huse, M., \& Solberg, A. G. (2006). Gender-related boardroom dynamics: How Scandinavian women make and can make contributions on corporate boards. Women in Management Review, 21, 113-130.

Ittonen, K., Miettinen, J., \& Vähämaa, S. (2010). Does female representation on audit committees affect audit fees? Quarterly Journal of Finance and Accounting, 49, 113-139.

Jianakoplos, N. A., \& Bernasek, A. (1998). Are women more risk averse? Economic Inquiry, 36, 620-630.

Kacer, M., Peel, D. A., Peel, M. J., \& Wilson, N. (2018). On the persistence and dynamics of Big 4 real audit fees: Evidence from the UK. Journal of Business Finance \& Accounting, 45, 714-727.

Kanter, R., (1977). Some effects of proportions on group life: Skewed sex ratios and responses to token women. American Journal of Sociology, 82, 965-990.

Kesner, I. F. (1988). Directors' characteristics and committee membership: An investigation of type, occupation, tenure, and gender. Academy of Management Journal, 31, 66-84.

Klein, A. (2002). Audit committee, board of director characteristics, and earnings management. Journal of Accounting and Economics, 33, 375-400.

Knechel, W. R. \& Willekens, M. (2006). The role of risk management and governance in determining audit demand. Journal of Business Finance \& Accounting, 33, 1344-1367.

Krishnan, G. V., \& Parsons, L. M. (2008). Getting to the bottom line: An exploration of gender and earnings quality. Journal of Business Ethics, 78, 65-76.

Krishnan, G., \& Visvanathan, G. (2009). Do auditors price audit committee's expertise? The case of accounting versus non-accounting financial experts. Journal of Accounting, Auditing \& Finance, 24, 115-144.

Kruisinga, S. A., \& Senden, L. (2017). Gender diversity on corporate boards in the Netherlands: Waiting on the world to change. In Gender Diversity in the Boardroom (pp. 177-204). Springer.

La Porta, R., Lopez-de-Silanes, F., Shleifer, A., \& Vishny, R. W. (1998). Law and finance. Journal of Political Economy, 106, 1113-1155.

Lai, K. M., Srinidhi, B., Gul, F. A., \& Tsui, J. (2017). Board gender diversity, auditor fees and auditor choice. Contemporary Accounting Research, 34, 1681-1714.

Leszczyńska, M. (2018). Mandatory quotas for women on boards of directors in the European Union: Harmful to or good for company performance? European Business Organization 
Law Review, 19, 35-61.

Levrau, A. (2017). Belgium: Male/female united in the boardroom. In Gender Diversity in the Boardroom (pp. 155-175). Springer.

Maida, A., \& Weber, A. (2019). Female leadership and gender gap within firms: Evidence from an Italian board reform. CEPR Discussion Paper No. DP13476. Available at SSRN: https://ssrn.com/abstract=3324211.

Maraghni, I., \& Nekhili, M. (2014). Audit committee diligence in French companies: A question of independence or competence? Comptabilité-Contrôle-Audit, 20, 95-124.

Mateos de Cabo, R., Terjesen, S., Escot, L., \& Gimeno, R. (2019). Do 'soft law' board gender quotas work? Evidence from a natural experiment. European Management Journal. https://doi.org/10.1016/J.EMJ.2019.01.004

Mitra, S., Hossain, M., \& Deis, D. R. (2007). The empirical relationship between ownership characteristics and audit fees. Review of Quantitative Finance and Accounting, 28, 257-285.

Nekhili, M., \& Cherif, M. (2011). Related parties transactions and firm's market value: the French case. Review of Accounting and Finance, 10, 291-315.

Nekhili, M., \& Gatfaoui, H. (2013). Are demographic attributes and firm characteristics drivers of gender diversity? Investigating women's positions on French boards of directors. Journal of Business Ethics, 118, 227-249.

Nekhili, M., Chakroun, H., \& Chtioui, T. (2018). Women's leadership and firm performance: Family versus nonfamily firms. Journal of Business Ethics, 153, 291-316.

Nekhili, M., Javed, F., \& Chtioui, T. (2018). Gender-diverse audit partners and audit fee premium: The case of mandatory joint audit. International Journal of Auditing, 22, 486502.

Nekhili, M., Nagati, H., Chtioui, T., \& Rebolledo, C. (2017). Corporate social responsibility disclosure and market value: Family versus nonfamily firms. Journal of Business Research, 77, 41-52.

Newman, D. P., Patterson, E. R., \& Smith, J. R. (2005). The role of auditing in investor protection. The Accounting Review, 80, 289-313.

Orbis BvD - Bureau Van Dijk - https://www.bvdinfo.com/

Peel, M. J., \& Makepeace, G. H. (2012). Differential audit quality, propensity score matching and Rosenbaum bounds for confounding variables. Journal of Business Finance \& Accounting, 39, 606-648.

Piscopo, J. M., \& Clark Muntean, S. (2018). Corporate quotas and symbolic politics in advanced democracies. Journal of Women, Politics \& Policy, 39, 285-309.

Powell, M., \& Ansic, D. (1997). Gender differences in risk behaviour in financial decisionmaking: An experimental analysis. Journal of Economic Psychology, 18, 605-628.

Pucheta-Martínez, M. C., Bel-Oms, I., \& Olcina-Sempere, G. (2016). Corporate governance, female directors and quality of financial information. Business Ethics: A European Review, 25, 363-385.

Roodman, D. (2009). How to do xtabond2: An introduction to difference and system GMM in Stata. The Stata Journal, 9, 86-136.

Rosenbaum, P. R., \& Rubin, D. B. (1983). The central role of the propensity score in observational studies for causal effects. Biometrika, 70, 41-55.

Schubert, R. (2006). Analyzing and managing risks-on the importance of gender differences in risk attitudes. Managerial Finance, 32, 706-715.

Seierstad, C., \& Opsahl, T. (2011). For the few not the many? The effects of affirmative action on presence, prominence, and social capital of women directors in Norway. Scandinavian Journal of Management, 27, 44-54.

Sila, V., Gonzalez, A., \& Hagendorff, J. (2016). Women on board: does boardroom gender diversity affect firm risk? Journal of Corporate Finance, 36, 26-53 . 
Singh, V., Point, S., Moulin, Y., \& Davila, A. (2015). Legitimacy profiles of women directors on top French company boards. Journal of Management Development, 34, 803-820.

Smith, N. (2018). Gender quotas on boards of directors. IZA World of Labor.

Srinidhi, B., Gul, F. A., \& Tsui, J. (2011). Female directors and earnings quality. Contemporary Accounting Research, 28, 1610-1644.

Srinidhi, B. N., He, S., \& Firth, M. (2014). The effect of governance on specialist auditor choice and audit fees in US family firms. The Accounting Review, 89, 2297-2329.

Teigen, M. (2012). Gender quotas for corporate boards in Norway: Innovative gender equality policy. In Women on corporate boards and in top management (pp. 70-90). Springer.

Terjesen, S., Aguilera, R. V, \& Lorenz, R. (2015). Legislating a woman's seat on the board: Institutional factors driving gender quotas for boards of directors. Journal of Business Ethics, 128, 233-251.

Turley, S., \& Zaman, M. (2004). The corporate governance effects of audit committees. Journal of Management and Governance, 8, 305-332.

Vafeas, N., \& Waegelein, J. F. (2007). The association between audit committees, compensation incentives, and corporate audit fees. Review of Quantitative Finance and Accounting, 28, 241-255.

Watson, J., \& McNaughton, M. (2007). Gender differences in risk aversion and expected retirement benefits. Financial Analysts Journal, 63, 52-62.

Wintoki, M. B., Linck, J. S., \& Netter, J. M. (2012). Endogeneity and the dynamics of internal corporate governance. Journal of Financial Economics, 105, 581-606 .

Zaman, M., Hudaib, M., \& Haniffa, R. (2011). Corporate governance quality, audit fees and non-audit services fees. Journal of Business Finance \& Accounting, 38, 165-197.

Zhang, M., Xu, H., Tong, L., \& Ye, T. (2018). International evidence on economic policy uncertainty and asymmetric adjustment of audit pricing: Big 4 versus non-big 4 auditors. Journal of Business Finance \& Accounting, 45, 728-756. 
TABLE 1

Descriptive statistics

\begin{tabular}{|c|c|c|c|c|c|c|c|}
\hline Variable & Mean & $\begin{array}{c}\text { Standard } \\
\text { Deviation }\end{array}$ & Minimum & Maximum & $\begin{array}{c}25 \text { th } \\
\text { percentile }\end{array}$ & $\begin{array}{c}50 \text { th } \\
\text { percentile }\end{array}$ & $\begin{array}{c}75 \text { th } \\
\text { percentile }\end{array}$ \\
\hline AUD_FEE (Thousands of euros) & 6939.32 & 8050.05 & 45.86 & 53400 & 1334.75 & 3672 & 9718.5 \\
\hline NAUD_FEE (Thousands of euros) & 586.85 & 1683.01 & 0 & 35510 & 6 & 200 & 641.3 \\
\hline PRFEM_BD & $18.40 \%$ & $15.50 \%$ & 0 & $66.67 \%$ & 0 & $15.38 \%$ & $30 \%$ \\
\hline NBFEM_BD & 2.19 & 1.98 & 0 & 8 & 0 & 1 & 3 \\
\hline$S H A N \_B D$ & 0.253 & 0.179 & 0 & 0.627 & 0.077 & 0.260 & 0.420 \\
\hline$B L A U \_B D$ & 0.384 & 0.253 & 0 & 0.723 & 0 & 0.429 & 0.611 \\
\hline PRFEM_INS & $8.16 \%$ & $9.98 \%$ & 0 & $50 \%$ & 0 & $6.25 \%$ & $13.33 \%$ \\
\hline NBFEM_INS & 0.93 & 1.15 & 0 & 6 & 0 & 1 & 1 \\
\hline PRFEM_IND & $10.24 \%$ & $13.37 \%$ & 0 & $66.67 \%$ & 0 & 0 & $18.18 \%$ \\
\hline NBFEM_IND & 1.26 & 1.67 & 0 & 8 & 0 & 0 & 2 \\
\hline PRFEM_ADC & $19.26 \%$ & $23.00 \%$ & 0 & $100 \%$ & 0 & 0 & $33.33 \%$ \\
\hline$N B F E M \_A D C$ & 0.74 & 0.91 & 0 & 5 & 0 & 0 & 1 \\
\hline$B I G$ & 1.40 & 0.585 & 0 & 2 & 1 & 1 & 1 \\
\hline$A U D \_T E N$ (Number of years) & 11.97 & 6.68 & 0 & 38.50 & 6.5 & 11 & 16 \\
\hline$B D \_\bar{S} I Z E$ (Number of directors) & 11.84 & 3.68 & 3 & 24 & 9 & 12 & 14 \\
\hline$B D \_I N D$ & $47.17 \%$ & $22.51 \%$ & 0 & $100 \%$ & $33.33 \%$ & $45.45 \%$ & $60 \%$ \\
\hline$B D \_M E E T$ (Number of meetings) & 7.14 & 3.36 & 1 & 30 & 5 & 7 & 9 \\
\hline$A D C \_S I Z E$ & 3.77 & 1.10 & 0 & 10 & 3 & 4 & 4 \\
\hline$A D C \_I N D$ & $68.82 \%$ & $28.12 \%$ & 0 & $100 \%$ & $50 \%$ & $66.67 \%$ & $100 \%$ \\
\hline$A D C_{-} M E E T$ (Number of meetings) & 4.65 & 2.19 & 1 & 19 & 3 & 4 & 6 \\
\hline FEM_CEO & $1.81 \%$ & $13.15 \%$ & 0 & 1 & 0 & 0 & 0 \\
\hline$D U A \bar{L}$ & $58.14 \%$ & $49.38 \%$ & 0 & 1 & 0 & 1 & 1 \\
\hline CEO_TEN (Number of years) & 8.05 & 7.34 & 0 & 51 & 3 & 6 & 10 \\
\hline FAM_OWN & $25.91 \%$ & $26.45 \%$ & 0 & $95.19 \%$ & 0 & $18.48 \%$ & $47.67 \%$ \\
\hline INST_OWN & $25.82 \%$ & $28.96 \%$ & 0 & $95.31 \%$ & 0 & $11.96 \%$ & $43.05 \%$ \\
\hline$L E V^{-}$ & $24.28 \%$ & $14.61 \%$ & $0.10 \%$ & $66.55 \%$ & $14.00 \%$ & $22.89 \%$ & $33.16 \%$ \\
\hline TOBIN & 1.21 & 1.08 & 0.22 & 7.03 & 0.63 & 0.89 & 1.35 \\
\hline LOSS & $13.14 \%$ & $34.12 \%$ & 0 & 1 & 0 & 0 & 0 \\
\hline$R \& D$ & $2.77 \%$ & $5.61 \%$ & 0 & $34.63 \%$ & 0 & 0 & $3.32 \%$ \\
\hline FOR_ASSETS & $20.13 \%$ & $30.03 \%$ & 0 & $94.41 \%$ & 0 & 0 & $39.23 \%$ \\
\hline$R E C \& I N V$ & $13.62 \%$ & $16.33 \%$ & 0 & $65.31 \%$ & $0.65 \%$ & $8.81 \%$ & $23.69 \%$ \\
\hline CROSS & $24.46 \%$ & $43.05 \%$ & 0 & 1 & 0 & 0 & 0 \\
\hline F_SIZE (Total assets in billions of euros) & 19.07 & 33.04 & 0.01 & 278.94 & 2.06 & 5.81 & 23.25 \\
\hline
\end{tabular}

This table reports descriptive statistics for audit fees, non-audit fees, female directorship and control variables for a sample containing French firms of SBF 120 index. The final sample contains unbalanced panel data for 97 French firms for the period between 2002 and 2017. AUD_FEE is the natural log of audit fees in thousands of euros; NAUD_FEE is the natural $\log$ of non-audit fees in thousands of euros; $P R F E M \_B D$ is the percentage of female directors to total directors; $N B F E M \_B D$ is the total number of female directors; 
SHAN_BD is the Shannon diversity index; $B L A U \_B D$ is the Blau diversity index; PRFEM_INS is the percentage of female insider board directors to total number of board members; NBFEM_INS is the number of female insider board directors; PRFEM_IND is the percentage of female non-executive independent directors to total number of board directors; NBFEM_IND is the number of female non-executive independent directors; PRFEM_ADC is the percentage of female audit committee members to total number of audit committee directors; NBFEM $A D C$ is the number of female audit committee members; $B I G$ is an ordinal variable coded 0 if the company is audited by non-Big auditors, 1 if the company is audited by only one Big auditor and 2 if the company is audited by two Big auditors; $A U D \_T E N$ is the natural log of the average number of years of the auditors-client relationship; $B D \_S I Z E$ is the natural $\log$ of the total number of directors; $B D \_I N D$ is the ratio of non-executive independent directors to total number of directors; $B D$ MEET is the natural $\log$ of the number of board meeting; $A D C$ SIZE is the total number of audit committee members; $A D C \_M E E T$ is the number of audit committee meeting. FEM CEO is a dummy variable coded 1 if the $C E O$ is a female and 0 otherwise; $D U A L$ is a dummy variable coded 1 if the CEO serves as board Chair and 0 otherwise; CEO_TEN is the natural log of the number of years served at the company before becoming CEO; FAM_OWN is the percentage of capital held by family investors; INST_OWN is the percentage of capital held by institutional investors; $L E V$ is the ratio of financial debt to total assets; TOBIN is the stock market capitalization plus book value of liabilities, scaled by the book value of assets; LOSS is a dummy variable equal to 1 if the firm reports a loss and 0 otherwise; $R \& D$ is the ratio of R\&D expenditures to total assets; FOR_ASSETS is the ratio of foreign assets to total assets; REC\&INV is the ratio of accounts receivable and inventory to total assets; CROSS is a dummy variable equal to 1 if the firm is simultaneously listed in France and the USA and 0 otherwise; F_SIZE is the natural log of firm's total assets. * represents significance at the $1 \%$ level. 


\section{TABLE 2}

Descriptive statistics by year for board size, the proportion of female insider directors, the proportion of female independent directors , audit committee size, and the proportion of women on audit committees

\begin{tabular}{|c|c|c|c|c|c|c|}
\hline & Column 1 & Column 2 & Column 3 & Column 4 & Column 5 & Column 6 \\
\hline Year & BD_SIZE & $\begin{array}{c}\text { PRFEM_BD } \\
(\%)\end{array}$ & $\begin{array}{c}\text { PRFEM_INS } \\
(\%)\end{array}$ & $\begin{array}{c}\text { PRFEM_IND } \\
(\%) \\
\end{array}$ & $A D C \_S I Z E$ & $\begin{array}{c}\text { PRFEM_ADC } \\
(\%)\end{array}$ \\
\hline 2002 & 11.19 & 6.40 & 5.75 & 0.65 & 3.45 & 2.90 \\
\hline 2003 & 11.40 & 6.91 & 6.19 & 0.72 & 3.48 & 3.59 \\
\hline 2004 & 11.44 & 7.44 & 6.77 & 0.67 & 3.49 & 4.49 \\
\hline 2005 & 11.45 & 8.21 & 7.35 & 0.86 & 3.55 & 5.72 \\
\hline 2006 & 11.18 & 8.61 & 7.64 & 0.97 & 3.62 & 6.76 \\
\hline 2007 & 11.27 & 7.95 & 5.34 & 2.61 & 3.57 & 8.76 \\
\hline 2008 & 11.59 & 7.98 & 4.94 & 3.05 & 3.71 & 9.72 \\
\hline 2009 & 11.54 & 9.12 & 5.47 & 3.65 & 3.80 & 11.47 \\
\hline 2010 & 12.06 & 12.80 & 6.58 & 6.22 & 3.83 & 16.10 \\
\hline 2011 & 12.16 & 17.92 & 8.59 & 9.33 & 3.85 & 18.96 \\
\hline 2012 & 12.21 & 21.16 & 8.95 & 12.21 & 3.88 & 23.46 \\
\hline 2013 & 12.15 & 26.42 & 10.64 & 15.98 & 3.95 & 28.36 \\
\hline 2014 & 12.44 & 31.15 & 10.46 & 20.49 & 4.01 & 32.66 \\
\hline 2015 & 12.20 & 34.62 & 10.78 & 23.84 & 3.95 & 34.21 \\
\hline 2016 & 12.44 & 40.29 & 12.05 & 28.24 & 3.97 & 40.79 \\
\hline 2017 & 12.48 & 40.22 & 12.11 & 28.11 & 3.98 & 40.80 \\
\hline Total & 11.84 & 18.40 & 8.16 & 10.24 & 3.77 & 19.26 \\
\hline $\begin{array}{l}\text { Analysis of variance for mean } \\
\text { difference test : F-value ( } p \text {-value) }\end{array}$ & $1.58(0.065)^{*}$ & $162.76(0.000) * * *$ & $6.32(0.000)^{* * *}$ & $126.83(0.000)^{* * *}$ & $2.79(0.000)^{* * *}$ & $43.87(0.000)^{* * *}$ \\
\hline Mann-Kendall test: Z-value ( $p$-value): & $4.56(0.000)^{* * *}$ & $29.12(0.000)^{* * *}$ & $8.17(0.000)^{* * *}$ & $29.17(0.000)^{* * *}$ & $6.61(0.000)^{* * *}$ & $22.13(0.000)^{* * *}$ \\
\hline
\end{tabular}

This table presents descriptive statistics by year for the number of board directors (Column 1), the proportion of female directors (Column 2 ), the proportion of female insider directors (Column 3), the proportion of female independent directors (Column 4), the number of audit committee members (Column 5), and the proportion of women on audit committees (Column 6). *, ***** represent significance at the $10 \%, 5 \%$ and $1 \%$ levels, respectively. 
TABLE 3

Pairwise correlation matrix

\begin{tabular}{|c|c|c|c|c|c|c|c|c|c|c|c|c|c|}
\hline & 1 & 2 & 3 & 4 & 5 & 6 & 7 & 8 & 9 & 10 & 11 & 12 & VIF \\
\hline 1.AUD_FEE & 1.000 & & & & & & & & & & & & \\
\hline 2. NAUD_FEE & $0.551 *$ & 1.000 & & & & & & & & & & & \\
\hline 3. FEMDIR_PER & 0.044 & -0.015 & 1.000 & & & & & & & & & & 2.61 \\
\hline 4. FEMDIR_NUM & $0.257 *$ & $0.101 *$ & $0.900 *$ & 1.000 & & & & & & & & & 2.65 \\
\hline 5. SHAN_BD & 0.055 & -0.018 & $0.961 *$ & $0.881 *$ & 1.000 & & & & & & & & \\
\hline 6. $B L A U \_B D$ & $0.068 *$ & -0.016 & $0.933^{*}$ & $0.855^{*}$ & $0.991 *$ & 1.000 & & & & & & & \\
\hline 7. PRFEM_INS & $-0.109 *$ & $-0.133^{*}$ & $0.535^{*}$ & $0.413 *$ & $0.563 *$ & $0.561 *$ & 1.000 & & & & & & \\
\hline 8. PRFEM_IND & $0.136^{*}$ & $0.084^{*}$ & $0.774 *$ & $0.750 *$ & $0.708 *$ & $0.675^{*}$ & $-0.118 *$ & 1.000 & & & & & \\
\hline 9. PRFEM_ADC & -0.037 & $-0.112 *$ & $0.613 *$ & $0.582 *$ & $0.604 *$ & $0.583^{*}$ & $0.348 *$ & $0.462 *$ & 1.000 & & & & \\
\hline 10. QUOTA & $0.092 *$ & -0.015 & $0.706^{*}$ & $0.712 *$ & $0.709 *$ & $0.686^{*}$ & $0.220^{*}$ & $0.667 *$ & $0.513^{*}$ & 1.000 & & & 2.47 \\
\hline 11. $\widetilde{B I G}$ & $0.346^{*}$ & $0.241^{*}$ & -0.027 & 0.058 & -0.033 & -0.026 & $-0.083^{*}$ & 0.031 & -0.059 & 0.022 & 1.000 & & 1.31 \\
\hline 12. AUDIT_TEN & $0.169^{*}$ & $0.102 *$ & $0.246^{*}$ & $0.316^{*}$ & $0.232 *$ & $0.222 *$ & 0.003 & $0.288^{*}$ & $0.178 *$ & $0.340 *$ & $0.117 *$ & 1.000 & 1.42 \\
\hline 13. BD_SIZ̄E & $0.536^{*}$ & $0.348^{*}$ & 0.004 & $0.332 *$ & 0.033 & 0.056 & $-0.154^{*}$ & $0.120 *$ & 0.016 & $0.135^{*}$ & $0.279 *$ & $0.235^{*}$ & 2.02 \\
\hline 14. BD_IND & $0.274 *$ & $0.140 *$ & $0.142 *$ & $0.130 *$ & $0.124 *$ & $0.121 *$ & $-0.167 *$ & $0.292 *$ & $0.072 *$ & $0.220 *$ & $0.123 *$ & $0.119 *$ & 2.46 \\
\hline 15. BD_MEET & $0.116^{*}$ & 0.055 & $0.122 *$ & $0.106^{*}$ & $0.130 *$ & $0.127 *$ & 0.044 & $0.113^{*}$ & $0.077 *$ & $0.070 *$ & $0.077^{*}$ & -0.041 & 1.32 \\
\hline 16. $A D C \_S I Z E$ & $0.323^{*}$ & $0.174 *$ & $0.080^{*}$ & $0.196 *$ & $0.092 *$ & $0.100 *$ & 0.007 & $0.088^{*}$ & $0.102 *$ & $0.146^{*}$ & 0.030 & $0.110^{*}$ & 1.50 \\
\hline 17. $A D C \_I N D$ & $0.106^{*}$ & -0.019 & $0.152 *$ & $0.119 *$ & $0.144^{*}$ & $0.138^{*}$ & -0.060 & $0.220 *$ & $0.119 *$ & $0.195^{*}$ & $0.112 *$ & $0.174^{*}$ & 1.92 \\
\hline 18. ADC_MEET & $0.390 *$ & $0.134 *$ & $0.163^{*}$ & $0.214 *$ & $0.168 *$ & $0.166^{*}$ & -0.021 & $0.205^{*}$ & $0.178 *$ & $0.210^{*}$ & $0.128 *$ & $0.103^{*}$ & 1.47 \\
\hline 19. $D U A \bar{L}$ & -0.035 & $-0.071 *$ & 0.048 & $0.086^{*}$ & 0.057 & 0.056 & 0.038 & 0.029 & 0.061 & $0.094 *$ & 0.000 & 0.010 & 1.31 \\
\hline 20. CEO_TEN & $-0.083^{*}$ & $-0.081 *$ & $0.171 *$ & $0.140 *$ & $0.146^{*}$ & $0.135^{*}$ & $0.114^{*}$ & $0.111 *$ & $0.172 *$ & $0.155^{*}$ & 0.028 & $0.131 *$ & 1.26 \\
\hline 21. FEM_CEO & $-0.238^{*}$ & $-0.161 *$ & 0.055 & -0.018 & 0.059 & 0.058 & $0.177 *$ & $-0.068^{*}$ & 0.007 & 0.020 & -0.053 & 0.014 & 1.22 \\
\hline 22. FAM_OWN & $-0.364^{*}$ & $-0.187 *$ & $-0.101 *$ & $-0.144^{*}$ & $-0.096^{*}$ & $-0.100^{*}$ & 0.042 & $-0.151^{*}$ & -0.048 & -0.054 & -0.045 & 0.039 & 1.78 \\
\hline 23. INST_OWN & $0.286^{*}$ & $0.240^{*}$ & $0.168 *$ & $0.232 *$ & $0.168^{*}$ & $0.168 *$ & $-0.078^{*}$ & $0.256^{*}$ & $0.116^{*}$ & $0.194^{*}$ & $0.171 *$ & $0.092 *$ & 1.62 \\
\hline 24. $L E V^{-}$ & $0.093^{*}$ & 0.014 & -0.040 & -0.041 & -0.041 & -0.032 & $-0.111 *$ & 0.032 & -0.005 & $-0.087^{*}$ & -0.028 & 0.008 & 1.17 \\
\hline 25. TOBIN & $-0.259 *$ & $-0.076^{*}$ & 0.056 & -0.025 & 0.029 & 0.018 & 0.045 & 0.031 & 0.067 & 0.013 & -0.013 & -0.055 & 1.29 \\
\hline 26. LOSS & $-0.085^{*}$ & -0.062 & -0.030 & -0.053 & -0.043 & -0.044 & -0.038 & -0.007 & -0.019 & -0.008 & 0.059 & -0.005 & 1.17 \\
\hline 27. $R \& D$ & $-0.101 *$ & -0.044 & -0.032 & -0.056 & -0.033 & -0.043 & $-0.091^{*}$ & 0.034 & 0.017 & 0.062 & 0.011 & 0.009 & 1.16 \\
\hline 28.FOR_ASSETS & -0.014 & $0.103^{*}$ & $-0.199 *$ & $-0.231 *$ & $-0.206^{*}$ & $-0.206^{*}$ & $-0.112 *$ & $-0.150^{*}$ & $-0.221 *$ & $-0.173^{*}$ & $-0.093^{*}$ & $-0.090^{*}$ & 1.25 \\
\hline 29. RECINV & $-0.139 *$ & -0.014 & $-0.169 *$ & $-0.235^{*}$ & $-0.169 *$ & $-0.172 *$ & -0.033 & $-0.170^{*}$ & $-0.232 *$ & $-0.225^{*}$ & -0.013 & $-0.137^{*}$ & 1.21 \\
\hline 30. CROSS & $0.418^{*}$ & $0.178 *$ & 0.002 & 0.064 & -0.001 & 0.001 & 0.056 & -0.038 & 0.062 & -0.017 & $0.123^{*}$ & 0.017 & 1.35 \\
\hline 31. $F \_S I Z E$ & $0.839 *$ & $0.452 *$ & $0.109 *$ & $0.296^{*}$ & $0.122 *$ & $0.137 *$ & -0.021 & $0.145^{*}$ & $0.128 *$ & $0.157 *$ & $0.313^{*}$ & $0.193^{*}$ & 2.45 \\
\hline
\end{tabular}


TABLE 3 (Continued)

\begin{tabular}{|c|c|c|c|c|c|c|c|c|c|c|c|c|c|}
\hline & 13 & 14 & 15 & 16 & 17 & 18 & 19 & 20 & 21 & 22 & 23 & 24 & 25 \\
\hline 13. BD_SIZE & 1.000 & & & & & & & & & & & & \\
\hline 14. BD_IND & 0.063 & 1.000 & & & & & & & & & & & \\
\hline 15. BD_MEET & -0.007 & -0.008 & 1.000 & & & & & & & & & & \\
\hline 16. $A D C \_S I Z E$ & $0.347 *$ & 0.021 & $0.088^{*}$ & 1.000 & & & & & & & & & \\
\hline 17. $A D C \_I N D$ & -0.062 & $0.584 *$ & -0.044 & $-0.116^{*}$ & 1.000 & & & & & & & & \\
\hline 18. ADC_MEET & $0.202 *$ & $0.102 *$ & $0.405^{*}$ & $0.236^{*}$ & $0.151^{*}$ & 1.000 & & & & & & & \\
\hline 19. DUAL & $0.077^{*}$ & $-0.152 *$ & 0.004 & -0.001 & -0.057 & 0.010 & 1.000 & & & & & & \\
\hline 20. CEO_TEN & 0.005 & -0.020 & -0.021 & $-0.146^{*}$ & $0.158 *$ & -0.061 & $0.179 *$ & 1.000 & & & & & \\
\hline 21.FEM_CEO & $-0.155^{*}$ & 0.019 & $0.070 *$ & $-0.090 *$ & $0.071^{*}$ & -0.058 & -0.021 & $0.123^{*}$ & 1.000 & & & & \\
\hline 22.FAM_OWN & $-0.193^{*}$ & $-0.359 *$ & $-0.201 *$ & $-0.224^{*}$ & $-0.162 *$ & $-0.238 *$ & -0.014 & $0.079 *$ & 0.045 & 1.000 & & & \\
\hline 23.INST_OWN & $0.193 *$ & $0.380 *$ & $0.068^{*}$ & $0.255^{*}$ & $0.204 *$ & $0.144 *$ & 0.003 & -0.020 & $-0.072 *$ & $-0.465^{*}$ & 1.000 & & \\
\hline 24. $L E V$ & 0.013 & 0.037 & $0.105^{*}$ & 0.045 & -0.043 & 0.045 & $-0.067 *$ & $-0.123 *$ & -0.035 & $-0.117 *$ & 0.001 & 1.000 & \\
\hline 25. TOBIN & $-0.177 *$ & $-0.119 *$ & 0.038 & $-0.073^{*}$ & -0.052 & -0.064 & $-0.123^{*}$ & $0.069 *$ & 0.025 & $0.195^{*}$ & $-0.177 *$ & $-0.068 *$ & 1.000 \\
\hline 26. LOSS & -0.042 & $0.105 *$ & $0.106^{*}$ & 0.022 & 0.046 & 0.041 & -0.002 & -0.064 & $0.130 *$ & $-0.144^{*}$ & 0.062 & $0.091 *$ & -0.011 \\
\hline 27. $R \& D$ & $-0.108 *$ & 0.008 & $0.098 *$ & -0.037 & $0.076^{*}$ & $0.078 *$ & -0.015 & 0.048 & -0.017 & $0.069 *$ & -0.040 & $-0.083^{*}$ & $0.121^{*}$ \\
\hline 28.FOR_ASSETS & $-0.091 *$ & $0.093 *$ & -0.004 & $-0.078 *$ & 0.018 & -0.067 & $-0.103^{*}$ & -0.062 & -0.048 & -0.003 & -0.038 & 0.063 & 0.053 \\
\hline 29. RECINV & $-0.171 *$ & -0.064 & 0.018 & $-0.119 *$ & -0.028 & $-0.069 *$ & $-0.115 *$ & -0.001 & $-0.066 *$ & 0.050 & $-0.160 *$ & $-0.178 *$ & $0.067 *$ \\
\hline 30. CROSS & $0.208 *$ & $0.171 *$ & $0.133^{*}$ & $0.141 *$ & $0.166^{*}$ & $0.236^{*}$ & $-0.093 *$ & $-0.093^{*}$ & $-0.078 *$ & $-0.221 *$ & $0.140 *$ & 0.032 & -0.032 \\
\hline 31. F_SIZE & $0.589 *$ & $0.201 *$ & 0.032 & $0.322 *$ & $0.071^{*}$ & $0.375^{*}$ & -0.010 & -0.062 & $-0.225^{*}$ & $-0.337^{*}$ & $0.277^{*}$ & $0.142 *$ & $-0.300^{*}$ \\
\hline
\end{tabular}

TABLE 3 (Continued)

\begin{tabular}{|c|c|c|c|c|c|}
\hline & 26 & 27 & 28 & 29 & 30 \\
\hline 26. LOSS & 1.000 & & & & \\
\hline 27. $R \& D$ & $0.084 *$ & 1.000 & & & \\
\hline 28.FOR_ASSETS & 0.042 & 0.013 & 1.000 & & \\
\hline 29. RECINV & -0.049 & 0.014 & $0.248 *$ & 1.000 & \\
\hline 30. CROSS & $0.101 *$ & $0.112 *$ & -0.027 & $-0.102 *$ & 1.000 \\
\hline 31. $F \_S I Z E$ & $-0.119 *$ & $-0.093 *$ & $-0.090 *$ & $-0.194 *$ & $0.322 *$ \\
\hline
\end{tabular}

This table presents correlations and VIF scores of the different variables used in our study. AUD_FEE is the natural log of audit fees in thousands of euros; NAUD_FEE is the natural $\log$ of non-audit fees in thousands of euros; PRFEM $B D$ is the percentage of female directors to total directors; $N B F E M \quad B D$ is the total number of female directors; SHAN_BD is the Shannon diversity index; $B L A U_{-} B D$ is the Blau diversity index; PRFEM_INS is the percentage of female insider board directors to total number of board members; NBFEM_INS is the number of female insider board directors; PRFEM_IND is the percentage of female non-executive independent directors to total number of board directors; NBFEM IND is the number of female non-executive independent directors; PRFEM ADC is the percentage of female audit committee members to total number of audit committee directors; NBFEM_ADC is the number of female audit committee members; QUOTA is a binary variable equal to 1 after the implementation of the quota law 
reform in 2012 and 0 otherwise; $B I G$ is an ordinal variable coded 0 if the company is audited by non-Big auditors, 1 if the company is audited by only one Big auditor and 2 if the company is audited by two Big auditors; $A U D \_T E N$ is the natural log of the average number of years of the auditors-client relationship; $B D \_S I Z E$ is the natural log of the total number of directors; $B D \_I N D$ is the ratio of non-executive independent directors to total number of directors; $B D \_M E E T$ is the natural log of the number of board meeting; $A D C \_S I Z E$ is the total number of audit committee members; $A D C \_M E E T$ is the number of audit committee meeting. FEM_CEO is a dummy variable coded 1 if the CEO is a female and 0 otherwise; $D U A L$ is a dummy variable coded 1 if the CEO serves as board Chair and 0 otherwise; $C E O$ TEN is the natural log of the number of years served at the company before becoming CEO; FAM_OWN is the percentage of capital held by family investors; INST_OWN is the percentage of capital held by institutional investors; $L E V$ is the ratio of financial debt to total assets; TOBIN is the stock market capitalization plus book value of liabilities, scaled by the book value of assets; $L O S S$ is a dummy variable equal to 1 if the firm reports a loss and 0 otherwise; $R \& D$ is the ratio of R\&D expenditures to total assets; FOR_ASSETS is the ratio of foreign assets to total assets; $R E C \& I N V$ is the ratio of accounts receivable and inventory to total assets; CROSS is a dummy variable equal to 1 if the firm is simultaneously listed in France and the USA and 0 otherwise; F_SIZE is the natural log of firm's total assets. * represents significance at the $1 \%$ level. 
TABLE 4

Mean difference test between firm-year observations with high proportion of female directors and firm-year observations with low proportion of female directors for entire and matched samples

\begin{tabular}{|c|c|c|c|c|c|c|}
\hline \multirow[t]{2}{*}{ Variable } & \multicolumn{3}{|c|}{ Entire Sample } & \multicolumn{3}{|c|}{ Matched Sample } \\
\hline & $\begin{array}{l}\text { FEM_BD } \\
>15.38 \%\end{array}$ & $\begin{array}{l}F E M \_B D \\
<15.38 \%\end{array}$ & t-value & Treatment & Control & t-value \\
\hline AUD_FEE (Thousands of euros) & 7596.3 & 7765.2 & 0.36 & 6594.2 & 8207.1 & $2.77 * * * a$ \\
\hline NAUD_FEE (Thousands of euros) & 774.26 & 611.34 & 1.63 & 690.79 & 553.92 & $1.02^{\mathrm{a}}$ \\
\hline$B I G$ & 1.44 & 1.48 & 1.38 & 1.46 & 1.45 & 0.26 \\
\hline$A U D \_T E N$ (Number of years) & 13.71 & 11.10 & $7.26 * * *$ & 12.307 & 12.184 & $0.28^{\mathrm{a}}$ \\
\hline BD_SIZE (Number of directors) & 11.79 & 11.83 & 0.21 & 12.18 & 12.39 & $0.94^{\mathrm{a}}$ \\
\hline$B D \_I N D$ & $50.82 \%$ & $45.68 \%$ & $4.49 * * *$ & $47.92 \%$ & $47.31 \%$ & 0.45 \\
\hline$B D \_M E E T$ (Number of meetings) & 7.48 & 6.67 & $4.77 * * *$ & 7.03 & 6.84 & $1.00^{\mathrm{a}}$ \\
\hline$A D C \_S I Z E$ & 3.84 & 3.68 & $2.79 * * *$ & 3.74 & 3.78 & 0.60 \\
\hline$A D C_{-} I N D$ & $71.36 \%$ & $64.38 \%$ & $5.16^{* * *}$ & $67.36 \%$ & $67.27 \%$ & 0.05 \\
\hline$A D C \_M E E T$ (Number of meetings) & 4.85 & 4.26 & $5.12 * * *$ & 4.56 & 4.65 & $0.64^{\mathrm{a}}$ \\
\hline$D U A \bar{L}$ & $59.82 \%$ & $54.19 \%$ & $2.08 * *$ & $57.80 \%$ & $56.46 \%$ & 0.02 \\
\hline CEO_TEN (Number of years) & 9.08 & 6.75 & $6.36 * * *$ & 7.91 & 7.27 & $1.38^{\mathrm{a}}$ \\
\hline FEM_CEO & $3.04 \%$ & $0.51 \%$ & $3.78 * * *$ & $1.57 \%$ & 0.90 & 0.91 \\
\hline FAM_OWN & $23.90 \%$ & $25.53 \%$ & 1.16 & $25.73 \%$ & $26.45 \%$ & 0.42 \\
\hline INST_OWN & $30.74 \%$ & $23.04 \%$ & $4.87 * * *$ & $25.51 \%$ & $26.92 \%$ & 0.75 \\
\hline$L E V$ & $23.44 \%$ & $25.10 \%$ & $2.16^{* *}$ & $24.20 \%$ & $24.21 \%$ & 0.01 \\
\hline TOBIN & 1.25 & 1.14 & $2.10 * *$ & 1.23 & 1.19 & 0.53 \\
\hline LOSS & $11.96 \%$ & $14.15 \%$ & $1.78 *$ & $12.47 \%$ & $12.25 \%$ & 0.10 \\
\hline$R \& D$ & $2.59 \%$ & $2.66 \%$ & 0.23 & $2.74 \%$ & $2.94 \%$ & 0.55 \\
\hline FOR_ASSETS & $16.21 \%$ & $27.37 \%$ & $6.95 * * *$ & $21.02 \%$ & $20.42 \%$ & 0.30 \\
\hline$R E C \bar{E} I N V$ & $12.03 \%$ & $16.39 \%$ & $4.88 * *$ & $14.16 \%$ & 13.71 & 0.42 \\
\hline CROSS & $24.52 \%$ & $29.68 \%$ & $2.12 * *$ & $27.13 \%$ & $27.35 \%$ & 0.07 \\
\hline F_SIZE (in billions of euros) & 20.58 & 17.22 & $2.02 * *$ & 19.12 & 20.61 & $0.36^{\mathrm{a}}$ \\
\hline Number of observations & 783 & 705 & & 457 & 457 & \\
\hline
\end{tabular}

This table reports the mean difference between firm-year observations with high proportion of female directors and firm-year observations with high proportion of female directors before and after matching for audit fees and control variables between 2002 and 2017. Propensity score matching yields a matched sample consisting of 914 cases: 457 treatment cases (firm-year observations with high proportion of female directors) and 457 comparison cases (firm-year observations with high proportion of female directors). AUD FEE is the natural log of audit fees in thousands of euros; NAUD FEE is the natural log of non-audit fees in thousands of euros; BIG is an ordinal variable coded 0 if the company is audited by non-Big auditors, 1 if the company is audited by only one Big auditor and 2 if the company is audited by two Big auditors; $A U D \_T E N$ is the natural $\log$ of the average number of years of the auditors-client relationship; BD_SIZE is the natural log of the total number of directors; $B D \_I N D$ is the ratio of nonexecutive independent directors to total number of directors; $B D \_M E E T$ is the natural log of the number of board meeting; $A D C$ SIZE is the total number of audit committee 
members; $A D C \_M E E T$ is the number of audit committee meeting. FEM_CEO is a dummy variable coded 1 if the CEO is a female and 0 otherwise; $D U A L$ is a dummy variable coded 1 if the CEO serves as board Chair and 0 otherwise; $C E O \quad T E N$ is the natural log of the number of years served at the company before becoming CEO; FAM $O W N$ is the percentage of capital held by family investors; INST OWN is the percentage of capital held by institutional investors; $L E V$ is the ratio of financial debt to total assets; TOBIN is the stock market capitalization plus book value of liabilities, scaled by the book value of assets; LOSS is a dummy variable equal to 1 if the firm reports a loss and 0 otherwise; $R \& D$ is the ratio of R\&D expenditures to total assets; FOR_ASSETS is the ratio of foreign assets to total assets; $R E C \& I N V$ is the ratio of accounts receivable and inventory to total assets; CROSS is a dummy variable equal to 1 if the firm is simultaneously listed in France and the USA and 0 otherwise; $F$ SIZE is the natural log of firm's total assets. $*, * *, * * *$ represent significance at the $10 \%, 5 \%$ and $1 \%$ levels, respectively. ${ }^{\text {a }}$ t-tests are based on natural logarithm-transformed values. 
TABLE 5

Regressions of audit fees on female directorship

\begin{tabular}{|c|c|c|c|c|c|c|c|}
\hline \multirow[t]{2}{*}{ Variables } & \multirow[t]{2}{*}{$\begin{array}{l}\text { Predicted } \\
\text { sign }\end{array}$} & \multicolumn{2}{|c|}{$\begin{array}{l}\text { Model 1: } \\
\text { OLS }\end{array}$} & \multicolumn{2}{|c|}{$\begin{array}{c}\text { Model 2: } \\
\text { Fixed effect }\end{array}$} & \multicolumn{2}{|c|}{$\begin{array}{c}\text { Model 3: } \\
\text { System GMM }\end{array}$} \\
\hline & & Coef. & t-test & Coef. & t-test & Coef. & t-test \\
\hline Lag AUD_FEE & + & & & & & $0.845 * * *$ & 62.05 \\
\hline PRFEM_BD & + & -0.334 & -1.49 & 0.136 & 0.82 & $-0.675 * * *$ & -14.10 \\
\hline$B I G$ & + & 0.066 & 1.51 & $0.149 * * *$ & 3.37 & 0.002 & 0.14 \\
\hline AUDIT_TEN & $?$ & -0.019 & -0.47 & 0.034 & 1.04 & $0.032 * *$ & 2.46 \\
\hline NAUD_FEE & + & $0.076^{* * *}$ & 9.28 & $0.014 * *$ & 2.01 & $0.007 * * *$ & 2.78 \\
\hline BD_SIZE & + & $0.339 * * *$ & 4.05 & 0.055 & 0.73 & $0.097 * * *$ & 3.72 \\
\hline$B D \_I N D$ & + & $0.610 * * *$ & 4.62 & -0.073 & -0.77 & 0.054 & 1.54 \\
\hline BD_MEET & + & $0.086^{*}$ & 1.77 & 0.037 & 1.13 & $0.025 * *$ & 2.19 \\
\hline$A D C \_S I Z E$ & + & -0.008 & -0.37 & -0.006 & -0.37 & $-0.010 * *$ & -2.01 \\
\hline$A D C \_I N D$ & + & -0.148 & -1.57 & $0.114 *$ & 1.74 & $-0.111 * * *$ & -4.54 \\
\hline$A D C \_M E E T$ & + & $0.133^{* *}$ & 2.16 & $0.203 * * *$ & 4.83 & -0.003 & -0.22 \\
\hline$D U A \bar{L}$ & + & -0.029 & -0.72 & -0.007 & -0.27 & 0.005 & 0.52 \\
\hline CEO_TEN & + & -0.004 & -0.14 & 0.020 & 1.08 & -0.001 & -0.25 \\
\hline FEM_CEO & + & -0.298 & -1.47 & -0.001 & -0.00 & 0.024 & 0.90 \\
\hline FAM_OWN & + & $-0.335 * * *$ & -3.41 & $0.231 * *$ & 2.08 & $-0.118 * * *$ & -4.39 \\
\hline INST_OWN & + & $-0.205^{* * *}$ & -2.56 & $-0.116^{*}$ & -1.71 & $-0.112 * * *$ & -6.51 \\
\hline$L E V$ & + & $0.293^{*}$ & 1.93 & $0.682 * * *$ & 5.38 & 0.040 & 0.87 \\
\hline TOBIN & - & -0.001 & -0.02 & $-0.034^{*}$ & -1.92 & 0.002 & 0.53 \\
\hline LOSS & + & $-0.102 *$ & -1.80 & -0.024 & -0.63 & $-0.044 * * *$ & -3.14 \\
\hline$R \& D$ & + & $-1.285 * * *$ & -3.08 & -0.263 & -0.47 & 0.003 & 0.02 \\
\hline FOR_ASSETS & + & -0.031 & -0.46 & -0.021 & -0.43 & $0.077 * * *$ & 3.30 \\
\hline RECINV & + & -0.127 & -1.01 & 0.185 & 1.49 & $0.065 * *$ & 2.05 \\
\hline CROSS & + & $0.510 * * *$ & 9.88 & $-2.273 * * *$ & -11.32 & $0.087 * * *$ & 5.87 \\
\hline$F \_S I Z E$ & + & $0.481 * * *$ & 20.23 & $0.247 * * *$ & 8.13 & $0.074 * * *$ & 7.86 \\
\hline Intercept & $?$ & -0.549 & -1.19 & $4.032 * * *$ & 7.85 & -0.035 & -0.33 \\
\hline Year & & \multicolumn{2}{|l|}{ Yes } & \multicolumn{2}{|c|}{ Yes } & \multicolumn{2}{|c|}{ Yes } \\
\hline Industry (?) & & \multicolumn{2}{|c|}{ Yes } & \multicolumn{2}{|c|}{ No } & \multicolumn{2}{|c|}{ Yes } \\
\hline Number of obs. & & \multicolumn{2}{|c|}{914} & \multicolumn{2}{|c|}{914} & \multicolumn{2}{|c|}{856} \\
\hline R-squared & & \multicolumn{2}{|c|}{$81.28 \%$} & \multicolumn{2}{|c|}{$39.49 \%$} & & \\
\hline $\mathrm{F}($ Prob $>\mathrm{F})$ & & \multicolumn{2}{|c|}{$64.70(p=0.000)$} & \multicolumn{2}{|c|}{$25.98(p=0.000)$} & \multicolumn{2}{|c|}{$8792.71(p=0.000)$} \\
\hline \multicolumn{6}{|c|}{ Arellano-Bond test $\mathrm{AR}(1)(\mathrm{z}, p$-value $)$ : } & \multirow{4}{*}{\multicolumn{2}{|c|}{$\begin{array}{r}-4.28(p=0.000) \\
-0.57(p=0.568) \\
735.03(p=0.000) \\
72.63(p=0.109)\end{array}$}} \\
\hline Arellano-Bond & $\mathrm{R}(2)(\mathrm{z}, p-$ & ue): & & & & & \\
\hline Sargan test (Chi- & re, $p$-value & & & & & & \\
\hline Hansen test $(\mathrm{Ch}$ & are, $p$-value & & & & & & \\
\hline
\end{tabular}

The table presents results of the OLS, the fixed effect, and the system GMM regressions of audit fees on the proportion of female directors for the matched sample. Matched sample analysis is carried out using the propensity score matching procedure (Rosenbaum \& Rubin, 1983). Propensity score matching yields a matched sample consisting of 914 cases: 457 treatment cases (firm-year observations with high proportion of female directors) and 457 comparison cases (firm-year observations with high proportion of female directors). AUD_FEE is the dependent variables and measured by the natural $\log$ of audit fees in thousands of euros; Lag AUD_FEE is the one-year lagged value of the natural log of audit fees; PRFEM_BD is the percentage of female directors to total directors; $B I G$ is an ordinal variable coded 0 if the company is audited by non-Big auditors, 1 if the company is audited by only one Big auditor and 2 if the company is audited by two Big auditors; AUD_TEN is the natural log of the average number of years of the auditors-client relationship; NAUD_FEE is the natural log of non-audit fees in thousands of euros; $B D \_S I Z E$ is the natural $\log$ of the total number of directors; $B D \_I N D$ is the ratio of nonexecutive independent directors to total number of directors; BD_MEET is the natural log of the number of board meeting; $A D C \_S I Z E$ is the total number of audit committee members; ADC_MEET is the number of audit committee meeting. FEM_CEO is a dummy variable coded 1 if the CEO is a female and 0 otherwise; DUAL is a dummy variable coded 1 if the CEO serves as board Chair and 0 otherwise; CEO_TEN is the natural log of the number of years served at the company before becoming CEO; FAM_OWN is the percentage of capital held by family investors; INST_OWN is the percentage of capital held by institutional investors; $L E V$ is the ratio of financial debt to total assets; TOBIN is the stock market capitalization plus book value of liabilities, scaled by the book value of assets; LOSS is a dummy variable equal to 1 if the firm reports a loss and 0 otherwise; $R \& D$ is the 
ratio of $\mathrm{R} \& \mathrm{D}$ expenditures to total assets; FOR_ASSETS is the ratio of foreign assets to total assets; $R E C \& I N V$ is the ratio of accounts receivable and inventory to total assets; CROSS is a dummy variable equal to 1 if the firm is simultaneously listed in France and the USA and 0 otherwise; F_SIZE is the natural log of firm's total assets. *, $* *, * * *$ represent significance at the $10 \%, 5 \%$ and $1 \%$ levels, respectively. 


\section{TABLE 6}

System GMM regressions of audit fees on the number of female directors, the Shannon diversity index and the Blau diversity index

\begin{tabular}{|c|c|c|c|c|c|c|c|}
\hline \multirow[t]{2}{*}{ Variables } & \multirow[t]{2}{*}{$\begin{array}{l}\text { Predicted } \\
\quad \text { sign }\end{array}$} & \multicolumn{2}{|c|}{$\begin{array}{c}\text { Model 1: } \\
\text { NBFEM_BD }\end{array}$} & \multicolumn{2}{|c|}{$\begin{array}{l}\text { Model 2: } \\
\text { SHAN_BD }\end{array}$} & \multicolumn{2}{|c|}{$\begin{array}{l}\text { Model 3: } \\
B L A U \_B D\end{array}$} \\
\hline & & Coef. & t-test & Coef. & t-test & Coef. & t-test \\
\hline Lag AUD_FEE & + & $0.840 * * *$ & 66.34 & $0.851 * * *$ & 56.85 & $0.853 * * *$ & 55.08 \\
\hline$N B F E M \_B D$ & + & $-0.043 * * *$ & -11.56 & & & & \\
\hline$S H A N \_B D$ & & & & $-0.570 * * *$ & -12.85 & & \\
\hline$B L A U \_B D$ & & & & & & $-0.448 * * *$ & -12.75 \\
\hline$B I G$ & + & 0.009 & 0.75 & -0.010 & -0.02 & 0.002 & 0.15 \\
\hline AUDIT_TEN & $?$ & $0.028 * *$ & 2.17 & $0.029 * *$ & 2.10 & $0.028 * *$ & 2.04 \\
\hline NAUD_FEE & + & $0.008 * * *$ & 3.43 & $0.008 * * *$ & 3.12 & $0.008 * * *$ & 3.17 \\
\hline BD_SIZE & + & $0.172 * * *$ & 7.04 & $0.102 * * *$ & 3.87 & $0.112 * * *$ & 4.25 \\
\hline BD_IND & + & $0.053 *$ & 1.91 & 0.038 & 1.07 & 0.036 & 0.90 \\
\hline$B D \_M E E T$ & + & $0.023 * *$ & 2.18 & $0.027 * *$ & 2.24 & $0.026 * *$ & 2.06 \\
\hline$A D C \_S I Z E$ & + & $-0.011 * *$ & -2.35 & $-0.010^{*}$ & -1.82 & -0.010 & -1.74 \\
\hline$A D C \_I N D$ & + & $-0.109 * * *$ & -5.16 & $-0.113 * * *$ & -4.57 & $-0.108 * * *$ & -4.27 \\
\hline$A D C \_M E E T$ & + & -0.001 & -0.02 & -0.001 & -0.09 & -0.002 & -0.15 \\
\hline$D U A L$ & + & 0.003 & 0.35 & 0.004 & 0.30 & -0.004 & -0.18 \\
\hline CEO_TEN & + & -0.004 & -0.60 & -0.003 & -0.41 & -0.003 & -0.48 \\
\hline FEM_CEO & + & -0.010 & -0.40 & 0.008 & 0.30 & 0.005 & 0.15 \\
\hline FAM_OWN & + & $-0.103 * * *$ & -3.91 & $-0.106 * * *$ & -4.09 & $-0.109 * * *$ & -4.46 \\
\hline INST_OWN & + & $-0.104 * * *$ & -6.44 & $-0.105 * * *$ & -6.95 & $-0.113 * * *$ & -7.24 \\
\hline$L E V$ & + & 0.019 & 0.44 & 0.034 & 0.75 & 0.023 & 0.50 \\
\hline TOBIN & - & 0.001 & 0.17 & -0.001 & -0.29 & -0.002 & -0.31 \\
\hline LOSS & + & $-0.041 * * *$ & -3.03 & $-0.045^{* * *}$ & -3.06 & $-0.045 * * *$ & -2.94 \\
\hline$R \& D$ & + & -0.049 & -0.48 & 0.012 & 0.10 & -0.020 & -0.16 \\
\hline FOR_ASSETS & + & $0.073 * * *$ & 3.66 & $0.079 * * *$ & 3.53 & $0.074 * * *$ & 3.56 \\
\hline$R E C I N V$ & + & $0.068 * *$ & 2.36 & $0.062 * *$ & 2.01 & $0.058 *$ & 1.81 \\
\hline CROSS & + & $0.091 * * *$ & 6.65 & $0.082 * * *$ & 4.92 & $0.079 * * *$ & 4.62 \\
\hline$F_{-} S I Z E$ & + & $0.075 * * *$ & 9.05 & $0.071 * * *$ & 7.13 & $0.070 * * *$ & 6.96 \\
\hline Intercept & $?$ & $-0.208 * *$ & -2.17 & -0.016 & -0.16 & 0.004 & 0.04 \\
\hline Year & & \multicolumn{2}{|l|}{ Yes } & \multicolumn{2}{|l|}{ Yes } & \multicolumn{2}{|c|}{ Yes } \\
\hline Industry (?) & & \multicolumn{2}{|c|}{ Yes } & \multicolumn{2}{|c|}{ Yes } & \multicolumn{2}{|c|}{ Yes } \\
\hline Number of obs. & & \multicolumn{2}{|c|}{856} & \multicolumn{2}{|c|}{856} & \multicolumn{2}{|c|}{856} \\
\hline $\mathrm{F}($ Prob $>\mathrm{F})$ & & \multicolumn{2}{|c|}{$7560.65(p=0.000)$} & \multicolumn{2}{|c|}{$10314.97(p=0.000)$} & \multicolumn{2}{|c|}{$5714.69(p=0.000)$} \\
\hline \multicolumn{2}{|c|}{$\begin{array}{l}\text { Arellano-Bond test } \mathrm{AR}(1)(\mathrm{z}, p- \\
\text { value): }\end{array}$} & \multicolumn{2}{|c|}{$-4.26(p=0.000)$} & \multicolumn{2}{|c|}{$-4.26(p=0.000)$} & \multicolumn{2}{|c|}{$-4.23(p=0.000)$} \\
\hline \multicolumn{2}{|c|}{$\begin{array}{l}\text { Arellano-Bond test } \mathrm{AR}(2)(\mathrm{z}, p- \\
\text { value): }\end{array}$} & \multicolumn{2}{|c|}{$-0.55(p=0.585)$} & \multicolumn{2}{|c|}{$-0.55(p=0.585)$} & \multicolumn{2}{|c|}{$-0.60(p=0.551)$} \\
\hline \multicolumn{2}{|c|}{$\begin{array}{l}\text { Sargan test (Chi-square, } p \text { - } \\
\text { value): }\end{array}$} & \multicolumn{2}{|c|}{$752.28(p=0.000)$} & $752.28(p=$ & $0.000)$ & $736.06(p$ & $0.000)$ \\
\hline $\begin{array}{l}\text { Hansen test (Chi- } \\
\text { value): }\end{array}$ & are, $p-$ & $72.62(p=$ & $0.110)$ & $72.62(p=$ & $0.110)$ & $71.05(p$ & $0.135)$ \\
\hline
\end{tabular}

The table presents results of the system GMM regressions of audit fees on the number of female directors, the Shannon diversity index and the Blau diversity index for the matched sample. Matched sample analysis is carried out using the propensity score matching procedure (Rosenbaum \& Rubin, 1983). Propensity score matching yields a matched sample consisting of 914 cases: 457 treatment cases (firm-year observations with high proportion of female directors) and 457 comparison cases (firm-year observations with high proportion of female directors). $A U D \_F E E$ is the dependent variables and measured by the natural log of audit fees in thousands of euros; Lag $A U D \_F E E$ is the one-year lagged value of the natural log of audit fees; NBFEM_BD is the total number of female directors; $S H A N \_B D$ is the Shannon diversity index; $B L A U_{-} B D$ is the Blau diversity index; $B I G$ is an ordinal variable coded 0 if the company is audited by non-Big auditors, 1 if the company is audited by only one Big auditor and 2 if the company is audited by two Big auditors; $A U D \_T E N$ is the natural log of the average number of years of the auditors-client relationship; NAUD_FEE is the natural log of non-audit fees in thousands of euros; BD_SIZE is the natural $\log$ of the total number of directors; $B D \_I N D$ is the ratio of non-executive independent directors to total number of directors; $B D \_M E E T$ is the natural log of the number of board meeting; ADC_SIZE is the total 
number of audit committee members; $A D C_{-}$MEET is the number of audit committee meeting. FEM_CEO is a dummy variable coded 1 if the CEO is a female and 0 otherwise; DUAL is a dummy variable coded 1 if the CEO serves as board Chair and 0 otherwise; $C E O \_T E N$ is the natural log of the number of years served at the company before becoming CEO; FAM_OWN is the percentage of capital held by family investors; INST_OWN is the percentage of capital held by institutional investors; $L E V$ is the ratio of financial debt to total assets; TOBIN is the stock market capitalization plus book value of liabilities, scaled by the book value of assets; LOSS is a dummy variable equal to 1 if the firm reports a loss and 0 otherwise; $R \& D$ is the ratio of R\&D expenditures to total assets; FOR_ASSETS is the ratio of foreign assets to total assets; REC\&INV is the ratio of accounts receivable and inventory to total assets; CROSS is a dummy variable equal to 1 if the firm is simultaneously listed in France and the USA and 0 otherwise; $F \_S I Z E$ is the natural log of firm's total assets. *, **, *** represent significance at the $10 \%, 5 \%$ and $1 \%$ levels, respectively. 
TABLE 7

Mean difference test between firm-year observations with high proportion of female insider directors and firm-year observations with low proportion of female insider directors for entire and matched samples

\begin{tabular}{|c|c|c|c|c|c|c|}
\hline \multirow[t]{2}{*}{ Variable } & \multicolumn{3}{|c|}{ Entire Sample } & \multicolumn{3}{|c|}{ Matched Sample } \\
\hline & $\begin{array}{c}\text { PRFEM_INS > } \\
6.25 \%\end{array}$ & $\begin{array}{c}\text { PRFEM_INS < } \\
6.25 \%\end{array}$ & t-value & Treatment & Control & t-value \\
\hline AUD_FEE (Thousand of euros) & 8099.3 & 7203.2 & $1.87 *$ & 7552.6 & 8592.5 & $1.68 *$ \\
\hline NAUD_FEE (Thousand of euros) & 764.57 & 495.62 & $3.11 * * *$ & 597.91 & 579.24 & $0.27^{\mathrm{a}}$ \\
\hline$B I G$ & 1.48 & 1.45 & 0.94 & 1.54 & 1.51 & 0.96 \\
\hline$A U D \_T E N$ (Number of years) & 12.63 & 12.47 & 0.43 & 12.70 & 12.39 & $0.67^{\mathrm{a}}$ \\
\hline BD_SIZE (Number of directors) & 12.85 & 11.77 & $5.78 * * *$ & 12.26 & 12.26 & $0.02^{\mathrm{a}}$ \\
\hline$B D \_I N D$ & $45.45 \%$ & $53.69 \%$ & $7.30^{* * *}$ & $51.20 \%$ & $51.23 \%$ & 0.02 \\
\hline$B D \_M E E T$ (Number of meetings) & 6.89 & 7.08 & 1.13 & 7.09 & 7.08 & $0.08^{\mathrm{a}}$ \\
\hline$A D \overline{D C} \_S I Z E$ & 3.87 & 3.72 & $2.35 * *$ & 3.77 & 3.78 & 0.10 \\
\hline$A D C_{-} I N D$ & $66.62 \%$ & $72.17 \%$ & $3.80 * * *$ & $69.72 \%$ & $71.27 \%$ & 0.89 \\
\hline$A D C \_M E E T$ (Number of meetings) & 4.62 & 4.72 & 0.85 & 4.76 & 4.81 & $0.34^{\mathrm{a}}$ \\
\hline$D U A \bar{L}$ & $58.70 \%$ & $54.58 \%$ & 1.46 & $55.31 \%$ & $56.02 \%$ & 0.20 \\
\hline CEO_TEN (Number of years) & 8.26 & 7.51 & $1.83 *$ & 7.88 & 7.55 & $0.67^{\mathrm{a}}$ \\
\hline FEM_CEO & $2.66 \%$ & $0.70 \%$ & $2.61 * * *$ & $0.98 \%$ & $1.05 \%$ & 0.08 \\
\hline FAM_OWN & $26.19 \%$ & $23.08 \%$ & $2.12 * *$ & $23.06 \%$ & $23.80 \%$ & 0.41 \\
\hline INST_OWN & $26.97 \%$ & $28.53 \%$ & 0.93 & $29.50 \%$ & $29.97 \%$ & 0.22 \\
\hline$L E V$ & $23.47 \%$ & $24.92 \%$ & $1.85^{*}$ & $24.67 \%$ & $24.93 \%$ & 0.28 \\
\hline TOBIN & 1.16 & 1.20 & 0.64 & 1.15 & 1.16 & 0.12 \\
\hline LOSS & $12.68 \%$ & $13.38 \%$ & 0.36 & $14.57 \%$ & $14.39 \%$ & 0.07 \\
\hline$R \& D$ & $1.82 \%$ & $3.64 \%$ & $6.29 * * *$ & $2.23 \%$ & $2.73 \%$ & 1.52 \\
\hline FOR_ASSETS & $18.52 \%$ & $24.74 \%$ & $3.58 * * *$ & $24.74 \%$ & $21.72 \%$ & 1.36 \\
\hline$R E C \& I N V$ & $13.19 \%$ & $14.46 \%$ & 1.35 & $14.98 \%$ & $13.51 \%$ & 1.27 \\
\hline CROSS & $29.50 \%$ & $23.24 \%$ & $2.49 * *$ & $24.94 \%$ & $26.70 \%$ & 0.56 \\
\hline F_SIZE (in billions of euros) & 23.78 & 14.81 & $4.71 * * *$ & 17.35 & 18.27 & $0.47^{\mathrm{a}}$ \\
\hline Number of observations & 812 & 676 & & 415 & 415 & \\
\hline
\end{tabular}

This table reports the mean difference between firm-year observations with high proportion of female insider directors and firm-year observations with high proportion of female insider directors before and after matching for audit fees and control variables between 2002 and 2017. Propensity score matching yields a matched sample consisting of 830 cases: 415 treatment cases (firm-year observations with high proportion of female insider directors) and 415 comparison cases (firm-year observations with high proportion of female insider directors). AUD FEE is the natural log of audit fees in thousands of euros; NAUD FEE is the natural log of non-audit fees in thousands of euros; BIG is an ordinal variable coded 0 if the company is audited by non-Big auditors, 1 if the company is audited by only one Big auditor and 2 if the company is audited by two Big auditors; $A U D$ TEN is the natural log of the average number of years of the auditors-client relationship; $B D \_S I Z E$ is the natural log of the total number of directors; $B D I I N D$ is the ratio of non-executive independent directors to total number of directors; $B D \_M E E T$ is the natural log of the number of board meeting; $A D C$ SIZE is the total number of audit 
committee members; $A D C \_M E E T$ is the number of audit committee meeting. FEM_CEO is a dummy variable coded 1 if the CEO is a female and 0 otherwise; DUAL is a dummy variable coded 1 if the CEO serves as board Chair and 0 otherwise; $C E O T E N$ is the natural log of the number of years served at the company before becoming CEO;

$F A M \_O W N$ is the percentage of capital held by family investors; INST_OWN is the percentage of capital held by institutional investors; $L E V$ is the ratio of financial debt to total assets; TOBIN is the stock market capitalization plus book value of liabilities, scaled by the book value of assets; $L O S S$ is a dummy variable equal to 1 if the firm reports a loss and 0 otherwise; $R \& D$ is the ratio of R\&D expenditures to total assets; FOR ASSETS is the ratio of foreign assets to total assets; REC\&INV is the ratio of accounts receivable and inventory to total assets; $C R O S S$ is a dummy variable equal to 1 if the firm is simultaneously listed in France and the USA and 0 otherwise; $F$ SIZE is the natural $\log$ of firm's total assets. *,**,** represent significance at the $10 \%, 5 \%$ and $1 \%$ levels, respectively. ${ }^{a}$ t-tests are based on natural logarithm-transformed values. 
TABLE 8

Mean difference test between firm-year observations with high proportion of female independent directors and firm-year observations with low proportion of female independent directors for entire and matched samples

\begin{tabular}{|c|c|c|c|c|c|c|}
\hline \multirow[t]{2}{*}{ Variable } & \multicolumn{3}{|c|}{ Entire Sample } & \multicolumn{3}{|c|}{ Matched Sample } \\
\hline & $\begin{array}{c}\text { PRFEM_IND } \\
>0\end{array}$ & $\begin{array}{c}\text { PRFEM_IND } \\
<0\end{array}$ & t-value & Treatment & Control & t-value \\
\hline$A U D \_F E E$ (Thousand of euros) & 8113.2 & 7186.7 & $1.93 *$ & 6840.5 & 7676.2 & $1.87 * \mathrm{a}$ \\
\hline NAUD_FEE (Thousand of euros) & 711.1 & 559.45 & $1.75^{*}$ & 590.39 & 578.95 & $0.09^{\mathrm{a}}$ \\
\hline$B I G$ & 1.47 & 1.46 & 0.31 & 1.45 & 1.45 & 0.12 \\
\hline AUD_TEN (Number of years) & 13.94 & 10.91 & $8.34 * * *$ & 12.28 & 12.19 & $0.20^{\mathrm{a}}$ \\
\hline$B D \_S I Z E$ (Number of directors) & 12.64 & 12.02 & $3.24 * * *$ & 12.28 & 12.28 & $0.00^{\mathrm{a}}$ \\
\hline$B D \_I N D$ & $52.98 \%$ & $44.70 \%$ & $7.33^{* * *}$ & $47.96 \%$ & $48.37 \%$ & 0.29 \\
\hline$B D \_M E E T$ (Number of meetings) & 7.24 & 6.67 & $3.45 * * *$ & 6.68 & 6.88 & $0.99^{\mathrm{a}}$ \\
\hline$A \overline{D C} \_S I Z E$ & 3.87 & 3.72 & $2.30 * *$ & 3.76 & 3.80 & 0.44 \\
\hline$A D C_{-} I N D$ & $72.92 \%$ & $64.65 \%$ & $5.70 * * *$ & $68.44 \%$ & $69.07 \%$ & 0.36 \\
\hline$A D C_{-} M E E T$ (Number of meetings) & 4.84 & 4.45 & $3.17 * * *$ & 4.63 & 4.81 & $1.43^{\mathrm{a}}$ \\
\hline$D U A \bar{L}$ & $60.62 \%$ & $52.29 \%$ & $2.96 * * *$ & $56.28 \%$ & $57.65 \%$ & 0.38 \\
\hline CEO_TEN (Number of years) & 8.46 & 7.26 & $2.95^{* * *}$ & 8.34 & 7.73 & $1.52^{\mathrm{a}}$ \\
\hline$F E M \_C E O$ & $1.18 \%$ & $2.46 \%$ & $1.72 *$ & $2.09 \%$ & $2.46 \%$ & 0.33 \\
\hline FAM_OWN & $21.97 \%$ & $28.12 \%$ & $4.20 * * *$ & $27.18 \%$ & $26.75 \%$ & 0.22 \\
\hline INST_OWN & $33.48 \%$ & $20.75 \%$ & $7.79 * * *$ & $25.23 \%$ & $25.43 \%$ & 0.10 \\
\hline$L E V$ & $24.18 \%$ & $24.06 \%$ & 0.15 & $23.96 \%$ & $24.03 \%$ & 0.06 \\
\hline TOBIN & 1.16 & 1.20 & 0.62 & 1.15 & 1.16 & 0.11 \\
\hline LOSS & $12.09 \%$ & $14.08 \%$ & 1.04 & $12.30 \%$ & $12.57 \%$ & 0.11 \\
\hline$R \& D$ & $2.75 \%$ & $2.52 \%$ & 0.77 & $2.44 \%$ & $2.59 \%$ & 0.42 \\
\hline FOR_ASSETS & $16.58 \%$ & $27.05 \%$ & $6.08 * * *$ & $22.44 \%$ & $20.23 \%$ & 0.96 \\
\hline$R E C \& I N V$ & $12.08 \%$ & $15.79 \%$ & $3.96 * * *$ & $13.11 \%$ & $12.97 \%$ & 0.12 \\
\hline CROSS & $24.63 \%$ & $29.05 \%$ & $1.76^{*}$ & $26.70 \%$ & $25.14 \%$ & 0.49 \\
\hline F_SIZE (in billions of euros) & 18.99 & 20.53 & $2.31 * *$ & 19.04 & 20.32 & $0.69^{\mathrm{a}}$ \\
\hline Number of observations & 733 & 755 & & 387 & 387 & \\
\hline
\end{tabular}

This table reports the mean difference between firm-year observations with high proportion of female nonexecutive independent directors and firm-year observations with low proportion of female nonexecutive independent directors before and after matching for audit fees and control variables between 2002 and 2017 . Propensity score matching yields a matched sample consisting of 774 cases: 387 treatment cases (firm-year observations with high proportion of female independent directors) and 387 comparison cases (firm-year observations with high proportion of female independent directors). AUD_FEE is the natural log of audit fees in thousands of euros; NAUD_FEE is the natural log of non-audit fees in thousands of euros; $B I G$ is an ordinal variable coded 0 if the company is audited by non-Big auditors, 1 if the company is audited by only one Big auditor and 2 if the company is audited by two Big auditors; $A U D$ TEN is the natural log of the average number of years of the auditors-client relationship; $B D$ SIZE is the natural log of the total number of directors; $B D I N D$ is the ratio of non-executive independent directors to total number of directors; $B D=M E E T$ is the natural log of the number of board 
meeting; $A D C \_S I Z E$ is the total number of audit committee members; $A D C \_M E E T$ is the number of audit committee meeting. FEM_CEO is a dummy variable coded 1 if the CEO is a female and 0 otherwise; DUAL is a dummy variable coded 1 if the CEO serves as board Chair and 0 otherwise; $C E O \_T E N$ is the natural log of the number of years served at the company before becoming CEO; FAM_OWN is the percentage of capital held by family investors; INST_OWN is the percentage of capital held by institutional investors; $L E V$ is the ratio of financial debt to total assets; TOBIN is the stock market capitalization plus book value of liabilities, scaled by the book value of assets; $L O S S$ is a dummy variable equal to 1 if the firm reports a loss and 0 otherwise; $R \& D$ is the ratio of R\&D expenditures to total assets; FOR ASSETS is the ratio of foreign assets to total assets; $R E C \& I N V$ is the ratio of accounts receivable and inventory to total assets; CROSS is a dummy variable equal to 1 if the firm is simultaneously listed in France and the USA and 0 otherwise; F_SIZE is the natural log of firm's total assets. $*$, **, *** represent significance at the $10 \%, 5 \%$ and $1 \%$ levels, respectively. ${ }^{\text {a }}$ t-tests are based on natural logarithm-transformed values. 
TABLE 9

Mean difference test between firm-year observations with high proportion of female audit committee members and firm-year observations with low proportion of female audit committee members for entire and matched samples

\begin{tabular}{|c|c|c|c|c|c|c|}
\hline \multirow[t]{2}{*}{ Variable } & \multicolumn{3}{|c|}{ Entire Sample } & \multicolumn{3}{|c|}{ Matched Sample } \\
\hline & $F E M \_A D C>0$ & $F E M \_A D C=0$ & t-value & Treatment & Control & t-value \\
\hline$A U D \_F E E$ (Thousand of euros) & 8136.2 & 7260.9 & $1.83 *$ & 6306.9 & 8784.8 & $3.79 * * * \mathrm{a}$ \\
\hline NAUD_FEE (Thousand of euros) & 697.92 & 587.97 & 1.14 & 745.27 & 634.17 & $0.69^{\mathrm{a}}$ \\
\hline$B I G$ & 1.45 & 1.47 & 0.44 & 1.44 & 1.41 & 0.80 \\
\hline$A U D \_T E N$ (Number of years) & 13.92 & 11.24 & $7.63 * * *$ & 12.50 & 12.49 & $0.00^{\mathrm{a}}$ \\
\hline$B D \_\bar{S} I Z E$ (Number of directors) & 12.85 & 11.88 & $5.01 * * *$ & 12.12 & 12.36 & $0.99^{\mathrm{a}}$ \\
\hline$B D \_I N D$ & $50.96 \%$ & $47.51 \%$ & $3.51 * * *$ & $49.66 \%$ & $49.46 \%$ & 0.13 \\
\hline BD_MEET (Number of meetings) & 7.25 & 6.72 & $3.64 * * *$ & 6.97 & 7.31 & $1.56^{\mathrm{a}}$ \\
\hline$A \overline{D C} \_S I Z E$ & 4.12 & 3.49 & $10.75^{* * *}$ & 3.70 & 3.72 & 0.28 \\
\hline$A D C_{-} I N D$ & $70.08 \%$ & $68.25 \%$ & $1.87 *$ & $68.64 \%$ & $69.48 \%$ & 0.44 \\
\hline$A D C \_M E E T$ (Number of meetings) & 4.88 & 4.45 & $4.24 * * *$ & 4.51 & 4.75 & $1.46^{\mathrm{a}}$ \\
\hline$D U A \bar{L}$ & $58.66 \%$ & $55.05 \%$ & 1.42 & $57.26 \%$ & $58.08 \%$ & 0.22 \\
\hline CEO_TEN (Number of years) & 8.45 & 7.40 & $2.81 * * *$ & 7.83 & 7.94 & $0.21^{\mathrm{a}}$ \\
\hline FEM_CEO & $2.12 \%$ & $1.42 \%$ & 1.09 & $1.64 \%$ & $1.92 \%$ & 0.28 \\
\hline FAM_OWN & $23.35 \%$ & $26.15 \%$ & $1.79 *$ & $24.51 \%$ & $23.47 \%$ & 0.56 \\
\hline INST_ŌOWN & $32.90 \%$ & $22.64 \%$ & $6.61 * * *$ & $25.93 \%$ & $26.09 \%$ & 0.08 \\
\hline$L E V$ & $25.04 \%$ & $23.26 \%$ & $2.31 * *$ & $24.04 \%$ & $25.11 \%$ & 1.02 \\
\hline TOBIN & 1.17 & 1.18 & 0.24 & 1.24 & 1.17 & 0.95 \\
\hline LOSS & $12.75 \%$ & $13.25 \%$ & 0.54 & $12.88 \%$ & $13.42 \%$ & 0.22 \\
\hline$R \& D$ & $2.40 \%$ & $2.88 \%$ & 1.57 & $2.27 \%$ & $2.54 \%$ & 0.72 \\
\hline FOR_ASSETS & $15.90 \%$ & $26.62 \%$ & $6.88 * * *$ & $21.36 \%$ & $21.91 \%$ & 0.24 \\
\hline$R E C \& I N V$ & $9.97 \%$ & $17.44 \%$ & $8.89 * * *$ & $14.26 \%$ & $13.86 \%$ & 0.32 \\
\hline CROSS & $28.59 \%$ & $24.76 \%$ & 1.46 & $25.48 \%$ & $28.49 \%$ & 0.92 \\
\hline F_SIZE (in billions of euros) & 24.10 & 15.44 & $4.56 * * *$ & 18.78 & 20.91 & $1.31^{\mathrm{a}}$ \\
\hline Number of observations & 658 & 659 & & 365 & 365 & \\
\hline
\end{tabular}

(the mean difference between firm-year observations with female on audit committee and firm-year observations without female on audit committee before and after matching for audit fees and control variables between 2002 and 2017. Propensity score matching yields a matched sample consisting of 730 cases: 365 treatment cases (firm-year observations with high proportion of female audit committee members) and 365 comparison cases (firm-year observations with high proportion of female audit committee members). AUD_FEE is the natural log of audit fees in thousands of euros; NAUD_FEE is the natural log of non-audit fees in thousands of euros; BIG is an ordinal variable coded 0 if the company is audited by non-Big auditors, 1 if the company is audited by only one Big auditor and 2 if the company is audited by two Big auditors; $A U D \_T E N$ is the natural log of the average number of years of the auditors-client relationship; $B D \_S I Z E$ is the natural log of the total number of directors; $B D \_I N D$ is the ratio of non-executive independent directors to total number of directors; $B D \_M E E T$ is the natural log of the number of board meeting; $A D C \_S I Z E$ is the total number of audit committee members; $A D C$ MEET is the number of audit committee meeting. FEM CEO is a dummy variable coded 1 if the CEO is a female and 0 otherwise; DUAL is a 
dummy variable coded 1 if the CEO serves as board Chair and 0 otherwise; CEO_TEN is the natural log of the number of years served at the company before becoming CEO; $F A M \_O W N$ is the percentage of capital held by family investors; INST_OWN is the percentage of capital held by institutional investors; $L E V$ is the ratio of financial debt to total assets; TOBIN is the stock market capitalization plus book value of liabilities, scaled by the book value of assets; LOSS is a dummy variable equal to 1 if the firm reports a loss and 0 otherwise; $R \& D$ is the ratio of $R \& D$ expenditures to total assets; FOR_ASSETS is the ratio of foreign assets to total assets; REC\&INV is the ratio of accounts receivable and inventory to total assets; $C R O S S$ is a dummy variable equal to 1 if the firm is simultaneously listed in France and the USA and 0 otherwise; $F$ SIZE is the natural $\log$ of firm's total assets. $* * *, * * *$ represent significance at the $10 \%, 5 \%$ and $1 \%$ levels, respectively. ${ }^{\text {a }}$ t-tests are based on natural logarithm-transformed values. 
TABLE 10

The system GMM regression of audit fees on female directorships and quota law

\begin{tabular}{|c|c|c|c|c|c|c|c|c|c|}
\hline \multirow[t]{2}{*}{ Variables } & \multirow[t]{2}{*}{$\begin{array}{l}\text { Predicted } \\
\text { sign }\end{array}$} & \multicolumn{2}{|c|}{$\begin{array}{c}\text { Model 1: } \\
\text { PRFEM_BD }\end{array}$} & \multicolumn{2}{|c|}{$\begin{array}{c}\text { Model 2: } \\
\text { PRFEM_INS }\end{array}$} & \multicolumn{2}{|c|}{$\begin{array}{c}\text { Model 3: } \\
\text { PRFEM_IND }\end{array}$} & \multicolumn{2}{|c|}{$\begin{array}{c}\text { Model 4: } \\
\text { PRFEM_ADC }\end{array}$} \\
\hline & & Coef. & t-test & Coef. & t-test & Coef. & t-test & Coef. & t-test \\
\hline Lag AUD_FEE & + & $0.866 * * *$ & 77.08 & $0.839 * * *$ & 101.86 & $0.886 * * *$ & 101.79 & $0.832 * * *$ & 55.14 \\
\hline PRFEM_BD & $?$ & $-0.757 * * *$ & -10.02 & & & & & & \\
\hline PRFEM_INS & $?$ & & & $0.151 * *$ & 2.13 & & & & \\
\hline PRFEM_IND & $?$ & & & & & $-0.982 * * *$ & -11.00 & & \\
\hline PRFEM_ADC & $?$ & & & & & & & $-0.799 * * *$ & -15.23 \\
\hline QUOTA & $?$ & $-0.041 * * *$ & -2.97 & $-0.112 * * *$ & -8.53 & $0.031 * *$ & 2.31 & $-0.047 * * *$ & -3.26 \\
\hline$B I G$ & + & 0.014 & 1.15 & -0.004 & -0.35 & $0.026 * * *$ & 2.92 & $0.057 * * *$ & 4.18 \\
\hline AUDIT_TEN & $?$ & 0.002 & 0.15 & $-0.019 * *$ & -2.36 & $-0.017 *$ & -1.85 & 0.018 & 1.54 \\
\hline$N A U D \_F E E$ & + & $0.010 * * *$ & 4.79 & $0.006 * * *$ & 3.27 & 0.002 & 0.69 & $0.009 * * *$ & 4.40 \\
\hline BD_SIZE & + & $0.046 * *$ & 2.25 & $0.124 * * *$ & 5.63 & 0.001 & 0.03 & 0.029 & 0.88 \\
\hline BD_IND & + & $0.060 * *$ & 2.05 & $0.128 * * *$ & 5.07 & -0.029 & -1.00 & $0.087 * *$ & 2.50 \\
\hline BD_MEET & + & 0.010 & 0.90 & $0.025 * * *$ & 3.43 & 0.002 & 0.20 & 0.006 & 0.43 \\
\hline$A D \bar{C} \_S I Z E$ & + & $-0.020 * * *$ & -5.27 & $-0.012 * * *$ & -2.91 & -0.001 & -0.03 & $-0.015^{*}$ & -1.76 \\
\hline$A D C_{-} I N D$ & + & $-0.081 * * *$ & -3.18 & $-0.080 * * *$ & -5.59 & $-0.034^{*}$ & -1.90 & $-0.062 *$ & -1.86 \\
\hline$A D C \_M E E T$ & + & 0.006 & 0.43 & $0.038 * * *$ & 4.02 & $0.031 * *$ & 2.13 & $0.033 * *$ & 2.30 \\
\hline$D U A \bar{L}$ & + & -0.001 & -0.16 & $0.016^{* *}$ & 2.38 & -0.002 & -0.20 & -0.006 & -0.56 \\
\hline CEO_TEN & + & $-0.010^{*}$ & -1.88 & 0.009 & 1.34 & $0.010^{*}$ & 1.94 & -0.001 & -0.05 \\
\hline FEM_CEO & + & $0.066 * * *$ & 2.97 & $-0.151 * * *$ & -6.19 & $-0.166 * * *$ & -8.72 & 0.033 & 1.27 \\
\hline$F A M \_O W N$ & + & $-0.087 * * *$ & -3.98 & -0.017 & -0.70 & $-0.110 * * *$ & -4.46 & $-0.129 * * *$ & -4.63 \\
\hline INST_OWN & + & $-0.055^{* * *}$ & -3.56 & -0.015 & -1.01 & $-0.044 * * *$ & -3.10 & $-0.079 * * *$ & -3.66 \\
\hline$L E V$ & + & $0.126^{* * *}$ & 3.25 & $0.099 * * *$ & 3.08 & -0.029 & -0.95 & -0.056 & -1.08 \\
\hline TOBIN & - & 0.006 & 1.63 & $0.012 * * *$ & 3.67 & $0.009 * * *$ & 2.77 & $0.021 * * *$ & 2.57 \\
\hline$L O S S$ & + & $-0.028 * *$ & -2.19 & $-0.025^{* *}$ & -2.18 & $-0.045^{* * *}$ & -4.23 & $-0.071 * * *$ & -4.48 \\
\hline$R \& D$ & + & -0.073 & -0.72 & 0.063 & 0.83 & -0.035 & -0.29 & 0.246 & 1.41 \\
\hline FOR_ASSETS & + & $0.031 *$ & 1.85 & -0.013 & -1.21 & $0.061 * * *$ & 3.87 & $0.044 * *$ & 2.08 \\
\hline$R E C I N V$ & + & $0.108 * * *$ & 3.85 & 0.002 & 0.07 & -0.039 & -1.58 & 0.002 & 0.05 \\
\hline CROSS & + & $0.055^{* * *}$ & 4.12 & $0.036 * * *$ & 3.53 & $0.025^{*}$ & 1.76 & $0.079 * * *$ & 4.62 \\
\hline$F \_S I Z E$ & + & $0.063 * * *$ & 8.17 & $0.086 * * *$ & 17.34 & $0.051 * * *$ & 7.20 & $0.080 * * *$ & 7.27 \\
\hline Intercept & $?$ & $0.154 *$ & 1.72 & $-0.360 * * *$ & -5.66 & $0.269 * * *$ & 3.80 & 0.133 & 1.14 \\
\hline Industry (?) & & \multicolumn{2}{|l|}{ Yes } & \multicolumn{2}{|c|}{ Yes } & \multicolumn{2}{|c|}{ Yes } & \multicolumn{2}{|c|}{ Yes } \\
\hline Number of obs. & & \multicolumn{2}{|c|}{856} & \multicolumn{2}{|c|}{817} & \multicolumn{2}{|c|}{744} & \multicolumn{2}{|c|}{685} \\
\hline
\end{tabular}




\section{TABLE 10}

(Continued)

\section{F (Prob > F)}

Arellano-Bond test AR(1) (z, p-value):

Arellano-Bond test AR(2) (z, p-value):

Sargan test (Chi-square, $p$-value):

Hansen test (Chi-square, $p$-value):

$10380.30(p=0.000)$
$-5.25(p=0.000)$
$-1.43(p=0.154)$
$673.60(p=0.000)$
$62.86(p=0.191)$

$9555.29(p=0.000)$
$-3.28(p=0.001)$
$0.64(p=0.519)$

$684.17(p=0.000)$

$68.55(p=0.185)$ $18529.73(p=0.000)$

$-4.86(p=0.000)$

$-1.12(p=0.185)$

$587.63(p=0.000)$

$66.72(p=0.202)$ $14613.69(p=0.000)$

$-4.21(p=0.000)$

$-1.15(p=0.250)$

$551.59(p=0.000)$

$62.71(p=0.208)$

The table presents results of the system GMM regressions of audit fees on quota law and the proportion of female directors (Model 1), the proportion of female insider directors (Model 2), the proportion of female independent directors (Model 3) and the proportion of female audit committee members (Model 4). AUD_FEE is the dependent variables and measured by the natural log of audit fees in thousands of euros; Lag AUD_FEE is the one-year lagged value of the natural log of audit fees; PRFEM_BD is the percentage of female directors to total directors; PRFEM INS is the percentage of female insider board directors to total number of board members; PRFEM IND is the percentage of female non-executive independent directors to total number of board directors; PRFEM_ADC is the percentage of female audit committee members to total number of audit committee directors; QUOTA is a binary variable equal to 1 after the implementation of the quota law reform in 2012 and 0 otherwise; $B I G$ is an ordinal variable coded 0 if the company is audited by non-Big auditors, 1 if the company is audited by only one Big auditor and 2 if the company is audited by two Big auditors; $A U D$ TEN is the natural log of the average number of years of the auditors-client relationship; NAUD_FEE is the natural log of non-audit fees in thousands of euros; $B D \_S I Z E$ is the natural log of the total number of directors; $B D \_I N D$ is the ratio of non-executive independent directors to total number of directors; $B D \_M E E T$ is the natural log of the number of board meeting; $A D C$ SIZE is the total number of audit committee members; $A D C$ MEET is the number of audit committee meeting. FEM CEO is a dummy variable coded 1 if the CEO is a female and 0 otherwise; $D U A L$ is a dummy variable coded 1 if the CEO serves as board Chair and 0 otherwise; $C E O \_T E N$ is the natural log of the number of years served at the company before becoming CEO; FAM_OWN is the percentage of capital held by family investors; INST_OWN is the percentage of capital held by institutional investors; $L E V$ is the ratio of financial debt to total assets; TOBIN is the stock market capitalization plus book value of liabilities, scaled by the book value of assets; $L O S S$ is a dummy variable equal to 1 if the firm reports a loss and 0 otherwise; $R \& D$ is the ratio of R\&D expenditures to total assets; FOR_ASSETS is the ratio of foreign assets to total assets; $R E C \& I N V$ is the ratio of accounts receivable and inventory to total assets; CROSS is a dummy variable equal to 1 if the firm is simultaneously listed in France and the USA and 0 otherwise; F_SIZE is the natural log of firm's total assets. *, **, *** represent significance at the $10 \%, 5 \%$ and $1 \%$ levels, respectively. 
TABLE 11

The system GMM regression of audit fees on the interaction between female directorships and quota law

\begin{tabular}{|c|c|c|c|c|c|c|c|c|c|}
\hline \multirow[t]{2}{*}{ Variables } & \multirow[t]{2}{*}{$\begin{array}{l}\text { Predicted } \\
\text { sign }\end{array}$} & \multicolumn{2}{|c|}{$\begin{array}{c}\text { Model 1: } \\
\text { PRFEM_BD*QUOTA }\end{array}$} & \multicolumn{2}{|c|}{$\begin{array}{c}\text { Model 2: } \\
\text { PRFEM_INS } * Q U O T A\end{array}$} & \multicolumn{2}{|c|}{$\begin{array}{c}\text { Model 3: } \\
\text { PRFEM_IND*QUOTA }\end{array}$} & \multicolumn{2}{|c|}{$\begin{array}{c}\text { Model 4: } \\
\text { PRFEM_ADC*QUOTA }\end{array}$} \\
\hline & & Coef. & $\mathrm{t}$-test & Coef. & t-test & Coef. & t-test & Coef. & t-test \\
\hline Lag AUD_FEE & + & $0.867 * * *$ & 77.68 & $0.852 * * *$ & 74.16 & $0.879 * * *$ & 81.12 & $0.824 * * *$ & 50.15 \\
\hline PRFEM_BD & $?$ & $-0.343 * * *$ & -3.73 & & & & & & \\
\hline PRFEM_BD*QUOTA & $?$ & $-0.697 * * *$ & -5.80 & & & & & & \\
\hline PRFEM_INS & $?$ & & & $1.179 * * *$ & 9.67 & & & & \\
\hline PRFEM_INS*QUOTA & $?$ & & & -0.241 & -1.52 & & & & \\
\hline PRFEM_IND & $?$ & & & & & $-0.374 * * *$ & -5.26 & & \\
\hline PRFEM_IND*QUOTA & $?$ & & & & & $-1.021 * * *$ & -9.31 & & \\
\hline PRFEM_ADC & $?$ & & & & & & & $-0.977 * * *$ & -15.17 \\
\hline PRFEM_ADC ${ }^{*} Q U O T A$ & $?$ & & & & & & & $-0.300 * * *$ & -3.89 \\
\hline QUOTA & $?$ & $0.153 * * *$ & 5.58 & 0.015 & 0.83 & $0.137 * * *$ & 6.29 & $0.111^{* * *}$ & 4.36 \\
\hline$B I G$ & + & $0.021 *$ & 1.93 & 0.008 & 0.63 & $0.032 * * *$ & 3.93 & $0.047 * * *$ & 3.06 \\
\hline AUDIT_TEN & $?$ & 0.009 & 0.85 & $-0.053^{* * *}$ & -5.15 & -0.014 & -1.34 & 0.019 & 1.45 \\
\hline NAUD_FEE & + & $0.011 * * *$ & 5.15 & 0.004 & 1.29 & 0.001 & 0.44 & $0.008 * * *$ & 3.69 \\
\hline BD_SIZ̄E & + & $0.051^{*}$ & 1.97 & $0.150 * * *$ & 4.49 & 0.039 & 1.47 & 0.049 & 1.47 \\
\hline BD_IND & + & $0.061 * *$ & 2.08 & $0.078 * *$ & 2.06 & -0.014 & -0.45 & $0.121 * * *$ & 3.03 \\
\hline$B D \_M E E T$ & + & 0.009 & 0.83 & -0.024 & -1.36 & 0.007 & 0.60 & 0.013 & 0.83 \\
\hline$A D C \_S I Z E$ & + & $-0.019 * * *$ & -4.45 & $-0.013^{* *}$ & -2.51 & -0.002 & -0.29 & $-0.016^{*}$ & -1.84 \\
\hline$A D C \_I N D$ & + & $-0.077 * * *$ & -2.93 & $-0.052 * *$ & -2.50 & -0.031 & -1.49 & $-0.066^{*}$ & -1.90 \\
\hline$A D C \_M E E T$ & + & 0.001 & 0.02 & $0.039 * * *$ & 3.75 & $0.026^{*}$ & 1.79 & $0.031 * *$ & 2.12 \\
\hline$D U A \bar{L}$ & + & 0.007 & 0.85 & $0.022 * *$ & 2.04 & -0.005 & -0.47 & -0.005 & -0.45 \\
\hline CEO_TEN & + & -0.008 & -1.50 & 0.006 & 0.72 & $0.012 * *$ & 2.21 & -0.001 & -0.08 \\
\hline FEM_CEO & + & $0.068 * * *$ & 2.72 & $-0.158 * * *$ & -4.69 & $-0.224 * * *$ & -8.94 & 0.039 & 1.51 \\
\hline FAM_OWN & + & $-0.096 * * *$ & -3.85 & -0.029 & -0.83 & $-0.131 * * *$ & -5.01 & $-0.105^{* * *}$ & -3.44 \\
\hline INST_OWN & + & $-0.052 * * *$ & -2.99 & -0.028 & -1.17 & $-0.042 * * *$ & -3.09 & $-0.084 * * *$ & -3.41 \\
\hline$L E V$ & + & $0.125 * * *$ & 3.14 & $0.155^{* * *}$ & 3.47 & -0.019 & -0.56 & -0.043 & -0.80 \\
\hline TOBIN & - & $0.009 * * *$ & 3.07 & $0.012^{*}$ & 1.90 & $0.014 * * *$ & 3.79 & $0.020 * *$ & 2.25 \\
\hline LOSS & + & $-0.031 * *$ & -2.39 & -0.021 & -1.42 & $-0.042 * * *$ & -3.81 & $-0.068 * * *$ & -4.32 \\
\hline$R \& D$ & + & -0.028 & -0.24 & -0.196 & -1.59 & -0.122 & -1.01 & 0.163 & 0.92 \\
\hline FOR_ASSETS & + & $0.038 * *$ & 2.45 & -0.005 & -0.30 & $0.057 * * *$ & 3.24 & $0.041 *$ & 1.90 \\
\hline RECINV & + & $0.095 * * *$ & 2.93 & $0.072 *$ & 1.83 & $-0.053 * *$ & -2.12 & -0.009 & -0.20 \\
\hline CROSS & + & $0.058 * * *$ & 4.40 & $0.041 * *$ & 2.50 & 0.027 & 1.60 & $0.085 * * *$ & 4.36 \\
\hline$F \_S I Z E$ & + & $0.060 * * *$ & 7.48 & $0.088 * * *$ & 12.06 & $0.049 * * *$ & 5.79 & $0.085 * * *$ & 7.47 \\
\hline Intercept & $?$ & 0.106 & 1.19 & $-0.503 * * *$ & -6.33 & $0.203 * * *$ & 2.60 & 0.077 & 0.59 \\
\hline
\end{tabular}


TABLE 11

(Continued)

\begin{tabular}{|c|c|c|c|c|}
\hline Industry (?) & Yes & Yes & Yes & Yes \\
\hline Number of obs. & 856 & 817 & 744 & 685 \\
\hline$F(\operatorname{Prob}>F)$ & $7968.22(p=0.000)$ & $7989.34(p=0.000)$ & $9584.20(p=0.000)$ & $3578.04(p=0.000)$ \\
\hline Arellano-Bond test $\mathrm{AR}(1)(\mathrm{z}, p$-value): & $-5.26(p=0.000)$ & $-3.25(p=0.000)$ & $-4.87(p=0.000)$ & $-4.20(p=0.000)$ \\
\hline Arellano-Bond test $\mathrm{AR}(2)(\mathrm{z}, p$-value): & $-1.42(p=0.155)$ & $0.66(p=0.510)$ & $-1.12(p=0.185)$ & $-1.07(p=0.283)$ \\
\hline Sargan test (Chi-square, $p$-value): & $667.86(p=0.000)$ & $119.31(p=0.000)$ & $581.38(p=0.000)$ & $546.17(p=0.000)$ \\
\hline Hansen test (Chi-square, $p$-value): & $71.88(p=0.189)$ & $63.41(p=0.231)$ & $71.41(p=0.195)$ & $72.39(p=0.197)$ \\
\hline Joint test: PRFEM_BD + PRFEM_BD*QUOTA & $-1.041 * * * \quad-10.13$ & & & \\
\hline Joint test: PRFEM_INS + PRFEM_INS*QUOTA & & $0.938 * * *$ & & \\
\hline Joint test: PRFEM_IND + PRFEM_IND*QUOTA & & & $-1.396 * * *$ & \\
\hline Joint test: PRFEM_ADC + PRFEM_ADC*QUOTA & & & & $-1.277 * * *$ \\
\hline
\end{tabular}

The table presents results of the system GMM regressions of audit fees on the interaction between female directorships and quota law (Model 1), the interaction between the proportion of female insider directors and quota law (Model 2), the interaction between the proportion of female independent directors and quota law (Model 3) and the interaction between the proportion of female audit committee members and quota law (Model 4). AUD_FEE is the dependent variables and measured by the natural log of audit fees in thousands of euros; Lag AUD FEE is the one-year lagged value of the natural log of audit fees; PRFEM BD is the percentage of female directors to total directors; PRFEM_INS is the percentage of female insider board directors to total number of board members; PRFEM_IND is the percentage of female non-executive independent directors to total number of board directors; PRFEM ADC is the percentage of female audit committee members to total number of audit committee directors; $Q U O T A$ is a binary variable equal to 1 after the implementation of the quota law reform in 2012 and 0 otherwise; $B I G$ is an ordinal variable coded 0 if the company is audited by non-Big auditors, 1 if the company is audited by only one Big auditor and 2 if the company is audited by two Big auditors; $A U D \_T E N$ is the natural log of the average number of years of the auditorsclient relationship; NAUD_FEE is the natural log of non-audit fees in thousands of euros; $B D \_S I Z E$ is the natural log of the total number of directors; $B D \_I N D$ is the ratio of non-executive independent directors to total number of directors; $B D$ MEET is the natural log of the number of board meeting; $A D C$ SIZE is the total number of audit committee members; $A D C \_M E E T$ is the number of audit committee meeting. FEM_CEO is a dummy variable coded 1 if the CEO is a female and 0 otherwise; $D U A L$ is a dummy variable coded 1 if the CEO serves as board Chair and 0 otherwise; CEO_TEN is the natural log of the number of years served at the company before becoming CEO; FAM_OWN is the percentage of capital held by family investors; INST $O W N$ is the percentage of capital held by institutional investors; $L E V$ is the ratio of financial debt to total assets; TOBIN is the stock market capitalization plus book value of liabilities, scaled by the book value of assets; LOSS is a dummy variable equal to 1 if the firm reports a loss and 0 otherwise; $R \& D$ is the ratio of $\mathrm{R} \& \mathrm{D}$ expenditures to total assets; FOR_ASSETS is the ratio of foreign assets to total assets; REC\&INV is the ratio of accounts receivable and inventory to total assets; CROSS is a dummy variable equal to 1 if the firm is simultaneously listed in France and the USA and 0 otherwise; $F \_S I Z E$ is the natural log of firm's total assets. $*, * *, * * *$ represent significance at the $10 \%, 5 \%$ and $1 \%$ levels, respectively. 
TABLE 12

The system GMM regression of audit fees on the interaction between female directorships (audit committee memberships) and firm size

\begin{tabular}{|c|c|c|c|c|c|c|c|c|}
\hline \multirow[t]{2}{*}{ Variables } & \multicolumn{2}{|c|}{$\begin{array}{c}\text { Model 1: } \\
\text { PRFEM_BD*SIZE_DUM }\end{array}$} & \multicolumn{2}{|c|}{$\begin{array}{c}\text { Model 2: } \\
\text { PRFEM_INS*SIZE_DUM }\end{array}$} & \multicolumn{2}{|c|}{$\begin{array}{c}\text { Model 3: } \\
\text { PRFEM_IND*SIZE_DUM }\end{array}$} & \multicolumn{2}{|c|}{$\begin{array}{c}\text { Model 4: } \\
\text { PRFEM_ADC*SIZE_DUM }\end{array}$} \\
\hline & Coef. & $\mathrm{t}$-test & Coef. & $\mathrm{t}-$ test & Coef. & $\mathrm{t}$-test & Coef. & t-test \\
\hline Lag AUD_FEE & $0.635 * * *$ & 24.03 & $0.471 * * *$ & 11.74 & $0.661 * * *$ & 21.70 & $0.656 * * *$ & 31.66 \\
\hline PRFEM_B $\bar{B} D$ & $0.256^{*}$ & 1.76 & & & & & & \\
\hline$S I Z E \_D U M$ & $1.357 * * *$ & 12.69 & $1.778 * * *$ & 11.13 & $1.048 * * *$ & 9.25 & $0.968 * * *$ & 12.06 \\
\hline PRFEM_BD*SIZE_DUM & $-1.749 * * *$ & -4.89 & & & & & & \\
\hline PRFEM_INS & & & $1.484 * * *$ & 3.02 & & & & \\
\hline PRFEM_INS*SIZE_DUM & & & $-2.370 * * *$ & -3.51 & & & & \\
\hline PRFEM_IND & & & & & -0.039 & -0.23 & & \\
\hline PRFEM_IND*SIZE_DUM & & & & & $-2.226 * * *$ & -4.45 & & \\
\hline PRFEM_ADC & & & & & & & $-0.731 * * *$ & -3.94 \\
\hline PRFEM_ADC*SIZE_DUM & & & & & & & -0.039 & -0.14 \\
\hline$Q_{U O T A}^{-}$ & $0.068 * * *$ & 5.11 & $-0.045 * *$ & -2.41 & $0.082 * * *$ & 4.43 & $-0.069 * * *$ & -3.29 \\
\hline$\widetilde{B I G}$ & -0.014 & -0.39 & 0.021 & 0.38 & -0.001 & -0.02 & -0.020 & -0.76 \\
\hline AUDIT_TEN & -0.003 & -0.11 & -0.069 & -1.52 & -0.025 & -0.94 & -0.021 & -0.61 \\
\hline NAUD_FEE & 0.009 & 1.59 & -0.006 & -0.82 & 0.007 & 1.43 & 0.001 & 0.39 \\
\hline BD_SIZE & -0.104 & -1.33 & -0.054 & -0.49 & -0.037 & -0.67 & -0.062 & -1.17 \\
\hline BD_IND & -0.020 & -0.26 & -0.031 & -0.33 & -0.033 & -0.41 & -0.033 & -0.42 \\
\hline BD_MEET & 0.037 & 1.39 & 0.017 & 0.57 & $0.048 *$ & 1.75 & $0.059 * *$ & 2.03 \\
\hline$A D C \_S I Z E$ & $-0.028 * *$ & -2.38 & $-0.034 * *$ & -2.33 & $-0.026 * * *$ & -3.02 & $-0.048 * * *$ & -4.46 \\
\hline$A D C \_I N D$ & -0.001 & -0.00 & -0.007 & -0.12 & -0.061 & -1.60 & 0.027 & 0.55 \\
\hline$A D C \_M E E T$ & 0.063 & 1.53 & $0.111 * * *$ & 2.55 & 0.027 & 0.72 & $0.063 * *$ & 2.41 \\
\hline$D U A L$ & $-0.457 * * *$ & -7.61 & $-1.207 * * *$ & -3.44 & $-0.406 * * *$ & -7.99 & $-0.416 * * *$ & -7.20 \\
\hline CEO_TEN & 0.023 & 0.73 & -0.016 & -0.49 & $0.048^{*}$ & 1.82 & 0.017 & 0.75 \\
\hline FEM_CEO & $-0.043 * *$ & -2.50 & $-0.063 * * *$ & -4.63 & $-0.054 * * *$ & -4.11 & -0.024 & -1.26 \\
\hline$F A M \_O W N$ & 0.039 & 0.56 & $0.328 * *$ & 2.43 & -0.074 & -1.06 & 0.117 & 1.27 \\
\hline INST_OWN & -0.124 & -1.76 & -0.079 & -0.93 & -0.048 & -1.16 & -0.028 & -0.51 \\
\hline$L E V$ & 0.017 & 0.14 & -0.061 & -0.40 & -0.010 & -0.13 & -0.086 & -0.84 \\
\hline TOBIN & $0.083^{* * *}$ & 7.18 & $0.084 * * *$ & 3.86 & $0.073 * * *$ & 6.45 & $0.090 * * *$ & 5.64 \\
\hline$L O S S$ & -0.001 & -0.03 & $0.186^{* * *}$ & 3.07 & -0.014 & -0.48 & 0.055 & 1.60 \\
\hline$R \& D$ & $-0.487 * * *$ & -2.59 & $-1.321 * * *$ & -2.65 & $-0.513 * * *$ & -2.97 & 0.261 & 0.92 \\
\hline FOR_ASSETS & -0.029 & -0.82 & 0.025 & 0.51 & -0.013 & -0.38 & 0.024 & 0.64 \\
\hline RECINV & $-0.238 *$ & -1.82 & $-0.332 * *$ & -2.50 & -0.116 & -1.30 & -0.175 & -1.54 \\
\hline CROSS & 0.064 & 1.29 & 0.036 & 0.58 & $0.070 * *$ & 1.99 & $0.081 * *$ & 2.01 \\
\hline Intercept & $2.645 * * *$ & 9.25 & $3.797 * * *$ & 9.55 & $2.528 * * *$ & 8.16 & $2.604 * * *$ & 11.06 \\
\hline
\end{tabular}


TABLE 12

(Continued)

Industry (?)

Number of obs.

F (Prob > F)

Arellano-Bond test AR(1) (z, $p$-value):

Arellano-Bond test $\mathrm{AR}(2)(\mathrm{z}, p$-value $)$ :

Sargan test (Chi-square, $p$-value):

Hansen test (Chi-square, $p$-value)

Joint test: PRFEM_BD + PRFEM_BD*SIZE_DUM

Joint test: PRFEM INS + PRFEM INS*SIZE_DUM

Joint test: PRFEM_IND + PRFEM_IND*SIZE_DUM

Joint test: PRFEM_ADC + PRFEM_ADC*SIZE_DUM
Yes
856

$4554.58(p=0.000)$

$-4.63(p=0.000)$

$-0.91(p=0.157)$

$550.35(p=0.000)$

$66.05(p=0.168)$

$-1.492 * * *$

$-6.14$

Yes
817
$1336.62(p=0.000)$
$-3.52(p=0.000)$
$-0.63(p=0.530)$
$483.32(p=0.000)$
$62.64(p=0.283)$

Yes

744

$2964.41(p=0.000)$

$-4.55(p=0.000)$

$-1.09(p=0.202)$

$582.91(p=0.000)$

$62.84(p=0.247)$
Yes

685

$8808.43(p=0.000)$

$-4.20(p=0.000)$

$-1.34(p=0.180)$

$508.69(p=0.000)$

$66.82(p=0.175)$

The table presents results of the system GMM regressions of audit fees on the interaction between female directorships and firm size (Model 1), the interaction between the proportion of female insider directors and firm size (Model 2), the interaction between the proportion of female independent directors and firm size (Model 3 ) and the interaction between the proportion of female audit committee members and firm size (Model 4). AUD_FEE is the dependent variables and measured by the natural log of audit fees in thousands of euros; $L a g$ AUD FEE is the one-year lagged value of the natural log of audit fees; PRFEM BD is the percentage of female directors to total directors; PRFEM INS is the percentage of female insider board directors to total number of board members; PRFEM_IND is the percentage of female non-executive independent directors to total number of board directors; PRFEM_ADC is the percentage of female audit committee members to total number of audit committee directors; $Q U O T A$ is a binary variable equal to 1 after the implementation of the quota law reform in 2012 and 0 otherwise; $B I G$ is an ordinal variable coded 0 if the company is audited by non-Big auditors, 1 if the company is audited by only one Big auditor and 2 if the company is audited by two Big auditors; AUD_TEN is the natural log of the average number of years of the auditors-client relationship; NAUD_FEE is the natural log of non-audit fees in thousands of euros; $B D \_S I Z E$ is the natural log of the total number of directors; $B D \_I N D$ is the ratio of nonexecutive independent directors to total number of directors; $B D$ MEET is the natural log of the number of board meeting; $A D C$ SIZE is the total number of audit committee members; $A D C \_M E E T$ is the number of audit committee meeting. FEM_CEO is a dummy variable coded 1 if the CEO is a female and 0 otherwise; $D U A L$ is a dummy variable coded 1 if the CEO serves as board Chair and 0 otherwise; CEO_TEN is the natural log of the number of years served at the company before becoming CEO; FAM_OWN is the percentage of capital held by family investors; INST $O W N$ is the percentage of capital held by institutional investors; $L E V$ is the ratio of financial debt to total assets; TOBIN is the stock market capitalization plus book value of liabilities, scaled by the book value of assets; LOSS is a dummy variable equal to 1 if the firm reports a loss and 0 otherwise; $R \& D$ is the ratio of $\mathrm{R} \& \mathrm{D}$ expenditures to total assets; FOR_ASSETS is the ratio of foreign assets to total assets; REC\&INV is the ratio of accounts receivable and inventory to total assets; CROSS is a dummy variable equal to 1 if the firm is simultaneously listed in France and the USA and 0 otherwise. *,**, *** represent significance at the $10 \%, 5 \%$ and $1 \%$ levels, respectively. 
TABLE 13

The system GMM regression of non-audit fees on female directorships and quota law

\begin{tabular}{|c|c|c|c|c|c|c|c|c|}
\hline \multirow[t]{2}{*}{ Variables } & \multicolumn{2}{|c|}{$\begin{array}{c}\text { Model 1: } \\
\text { PRFEM_BD }\end{array}$} & \multicolumn{2}{|c|}{$\begin{array}{c}\text { Model 2: } \\
\text { PRFEM_INS }\end{array}$} & \multicolumn{2}{|c|}{$\begin{array}{c}\text { Model 3: } \\
\text { PRFEM_IND }\end{array}$} & \multicolumn{2}{|c|}{$\begin{array}{c}\text { Model 4: } \\
\text { PRFEM_ADC }\end{array}$} \\
\hline & Coef. & t-test & Coef. & $\mathrm{t}$-test & Coef. & t-test & Coef. & t-test \\
\hline Lag NAUD_FEE & $0.785 * * *$ & 62.07 & $0.777 * * *$ & 63.37 & $0.793 * * *$ & 53.50 & $0.792 * * *$ & 42.06 \\
\hline PRFEM_BD & $-1.426^{* * *}$ & -3.89 & & & & & & \\
\hline PRFEM_INS & & & $-0.983 * * *$ & -3.22 & & & & \\
\hline PRFEM_IND & & & & & $-1.381 * * *$ & -3.58 & & \\
\hline PRFEM_ADC & & & & & & & $-1.629 * * *$ & -10.94 \\
\hline QUOTA & $0.313 * * *$ & 3.54 & -0.070 & -1.19 & -0.058 & -0.69 & $0.857 * * *$ & 13.76 \\
\hline$B I G$ & $0.178 * * *$ & 2.99 & -0.033 & -0.77 & $0.162 * * *$ & 2.61 & 0.057 & 1.09 \\
\hline$A U D \_F E E$ & $0.390 * * *$ & 8.98 & $0.351 * * *$ & 5.25 & $0.143 * * *$ & 2.62 & $0.271 * * *$ & 4.70 \\
\hline AUDIT_TEN & $0.145^{* * *}$ & 3.50 & $0.263 * * *$ & 6.13 & $0.089 * *$ & 2.08 & -0.023 & -0.43 \\
\hline BD_SIZE & $-0.237 * *$ & -2.09 & -0.126 & -0.92 & -0.081 & -0.55 & $-0.205^{*}$ & -1.97 \\
\hline BD_IND & 0.017 & 0.12 & 0.201 & 1.46 & $0.359 * *$ & 2.20 & $-0.326^{*}$ & -1.94 \\
\hline BD_MEET & $0.159 * * *$ & 2.79 & 0.020 & 0.58 & $0.172 * * *$ & 3.53 & $0.100 *$ & 1.67 \\
\hline$A \overline{D C} \_S I Z E$ & 0.015 & 0.79 & 0.033 & 1.55 & $0.050 * *$ & 2.09 & -0.011 & -0.42 \\
\hline$A D C \_I N D$ & $-0.196^{*}$ & -1.95 & $-0.470 * * *$ & -6.73 & $-0.257 * *$ & -2.45 & -0.012 & -0.10 \\
\hline$A D C \_M E E T$ & $-0.286^{* * *}$ & -3.49 & 0.066 & 0.97 & $-0.317 * * *$ & -5.36 & $-0.282 * * *$ & -4.88 \\
\hline$D U A \bar{L}$ & 0.049 & 1.06 & $0.131 * * *$ & 3.63 & -0.006 & -0.10 & $-0.120 * * *$ & -2.74 \\
\hline CEO_TEN & $-0.068 * * *$ & -3.11 & -0.028 & -1.26 & -0.016 & -0.64 & $-0.075 * *$ & -2.35 \\
\hline FEM_CEO & 1.202 & 0.85 & 0.126 & 1.40 & 0.073 & 0.37 & -0.157 & -0.73 \\
\hline FAM_OWN & $0.222 *$ & 1.91 & $0.175^{* *}$ & 2.30 & $0.196^{*}$ & 1.65 & $0.264 * *$ & 2.05 \\
\hline INST_OWN & $0.323 * * *$ & 2.62 & $0.591 * * *$ & 7.24 & $0.486^{* * *}$ & 5.39 & $0.230 * *$ & 2.43 \\
\hline$L E V$ & -0.196 & -0.86 & $-0.292 *$ & -1.83 & -0.007 & -0.04 & 0.148 & 0.71 \\
\hline TOBIN & -0.021 & -0.97 & -0.001 & -0.06 & 0.007 & 0.32 & $0.033 *$ & 1.79 \\
\hline$L O S S$ & -0.039 & -0.45 & -0.018 & -0.33 & -0.110 & -1.23 & $0.130 * *$ & 2.35 \\
\hline$R \& D$ & $-1.401 * *$ & -2.55 & 0.361 & 0.88 & -0.885 & -1.32 & $-1.166^{* * *}$ & -3.19 \\
\hline FOR_ASSETS & $0.435 * * *$ & 7.11 & $0.391 * * *$ & 7.09 & $0.353 * * *$ & 3.62 & 0.105 & 1.30 \\
\hline$R E C I N V$ & 0.121 & 0.62 & -0.075 & -0.60 & $-0.403 * * *$ & -2.59 & $-0.337 * * *$ & -3.65 \\
\hline CROSS & $-0.198 * *$ & -2.36 & $-0.089 *$ & -1.69 & $-0.240 * * *$ & -3.40 & 0.008 & 0.17 \\
\hline$F \_S I Z E$ & -0.016 & -0.57 & $-0.069 * *$ & -2.25 & 0.027 & 0.68 & $0.071 * *$ & 2.05 \\
\hline Intercept & $-1.481 * * *$ & -3.66 & $-1.293 * * *$ & -3.81 & -0.738 & -1.59 & $-1.445 * * *$ & -3.69 \\
\hline Industry (?) & \multirow{2}{*}{\multicolumn{2}{|c|}{$\begin{array}{l}\text { Yes } \\
856\end{array}$}} & \multicolumn{2}{|c|}{ Yes } & \multicolumn{2}{|c|}{ Yes } & \multicolumn{2}{|c|}{ Yes } \\
\hline Number of obs. & & & & & & & & \\
\hline
\end{tabular}




\section{TABLE 13}

(Continued)

\section{F $($ Prob $>$ F $)$}

Arellano-Bond test AR(1) (z,p-value):

Arellano-Bond test $\operatorname{AR}(2)(\mathrm{z}, p$-value):

Sargan test (Chi-square, $p$-value):

Hansen test (Chi-square, $p$-value):

$$
\begin{array}{r}
18191.64(p=0.000) \\
-4.52(p=0.000) \\
-0.90(p=0.367) \\
684.27(p=0.000)
\end{array}
$$

7608

$$
\begin{array}{r}
7608.01(p=0.000) \\
-4.35(p=0.000) \\
-0.08(p=0.940) \\
663.77(p=0.000) \\
67.71(p=0.204)
\end{array}
$$$$
67.71(p=0.204)
$$

$$
\begin{array}{r}
3328.07(p=0.000) \\
-5.01(p=0.000) \\
-1.36(p=0.173) \\
114.10(p=0.000)
\end{array}
$$$$
64.28(p=0.209)
$$
$10826.46(p=0.000)$
$-4.86(p=0.000)$
$-0.46(p=0.648)$
$608.20(p=0.000)$
$70.10(p=0.132)$

The table presents results of the system GMM regressions of non-audit fees on quota law and the proportion of female directors (Model 1), the proportion of female insider directors (Model 2), the proportion of female independent directors (Model 3) and the proportion of female audit committee members (Model 4). NAUD_FEE is the dependent variables and measured by the natural log of non-audit fees in thousands of euros; Lag NAUD_FEE is the one-year lagged value of the natural log of non-audit fees; $P R F E M \_B D$ is the percentage of female directors to total directors; PRFEM INS is the percentage of female insider board directors to total number of board members; PRFEM IND is the percentage of female non-executive independent directors to total number of board directors; PRFEM_ADC is the percentage of female audit committee members to total number of audit committee directors; QUOTA is a binary variable equal to 1 after the implementation of the quota law reform in 2012 and 0 otherwise; $B I G$ is an ordinal variable coded 0 if the company is audited by non-Big auditors, 1 if the company is audited by only one Big auditor and 2 if the company is audited by two Big auditors; $A U D$ TEN is the natural log of the average number of years of the auditors-client relationship; $A U D \_F E E$ is the natural log of audit fees in thousands of euros; $B D \_S I Z E$ is the natural log of the total number of directors; $B D \_I N D$ is the ratio of non-executive independent directors to total number of directors; $B D \_M E E T$ is the natural log of the number of board meeting; $A D C$ SIZE is the total number of audit committee members; $A D C$ MEET is the number of audit committee meeting. FEM CEO is a dummy variable coded 1 if the CEO is a female and 0 otherwise; DUAL is a dummy variable coded 1 if the CEO serves as board Chair and 0 otherwise; $C E O \_T E N$ is the natural log of the number of years served at the company before becoming CEO; FAM_OWN is the percentage of capital held by family investors; INST_OWN is the percentage of capital held by institutional investors; $L E V$ is the ratio of financial debt to total assets; TOBIN is the stock market capitalization plus book value of liabilities, scaled by the book value of assets; $L O S S$ is a dummy variable equal to 1 if the firm reports a loss and 0 otherwise; $R \& D$ is the ratio of R\&D expenditures to total assets; FOR_ASSETS is the ratio of foreign assets to total assets; REC\&INV is the ratio of accounts receivable and inventory to total assets; CROSS is a dummy variable equal to 1 if the firm is simultaneously listed in France and the USA and 0 otherwise; $F \_S I Z E$ is the natural log of firm's total assets. *, **,*** represent significance at the $10 \%, 5 \%$ and $1 \%$ levels, respectively. 
TABLE 14

The system GMM regression of non-audit fees on the interaction between female directorships and quota law

\begin{tabular}{|c|c|c|c|c|c|c|c|c|}
\hline \multirow[t]{2}{*}{ Variables } & \multicolumn{2}{|c|}{$\begin{array}{c}\text { Model 1: } \\
\text { PRFEM_BD*QUOTA }\end{array}$} & \multicolumn{2}{|c|}{$\begin{array}{c}\text { Model 2: } \\
\text { PRFEM_INS*QUOTA }\end{array}$} & \multicolumn{2}{|c|}{$\begin{array}{c}\text { Model 3: } \\
\text { PRFEM_IND*QUOTA }\end{array}$} & \multicolumn{2}{|c|}{$\begin{array}{c}\text { Model 4: } \\
\text { PRFEM_ADC*QUOTA }\end{array}$} \\
\hline & Coef. & t-test & Coef. & $\mathrm{t}$-test & Coef. & t-test & Coef. & t-test \\
\hline Lag NAUD_FEE & $0.808^{* * *}$ & 52.32 & $0.784 * * *$ & 44.60 & $0.796 * * *$ & 55.29 & $0.788 * * *$ & 39.46 \\
\hline PRFEM_BD & $-1.099 * *$ & -2.01 & & & & & & \\
\hline PRFEM_BD*QUOTA & 0.976 & 1.31 & & & & & & \\
\hline PRFEM_INS & & & $-4.028 * * *$ & -6.82 & & & & \\
\hline PRFEM_INS*QUOTA & & & $5.471 * * *$ & 5.43 & & & & \\
\hline PRFEM_IND & & & & & 0.388 & 0.75 & & \\
\hline PRFEM_IND*QUOTA & & & & & $-2.758 * * *$ & -2.79 & & \\
\hline PRFEM_ADC & & & & & & & $-4.286^{* * *}$ & -17.56 \\
\hline PRFEM_ADC ${ }^{*} Q U O T A$ & & & & & & & $4.284 * * *$ & 12.28 \\
\hline QUOTA & -0.143 & -1.11 & $-0.546^{* * *}$ & -3.93 & 0.156 & 1.15 & -0.109 & -1.04 \\
\hline$B I G$ & 0.005 & 0.08 & $-0.099 * *$ & -2.14 & $0.182 * * *$ & 3.01 & 0.045 & 0.76 \\
\hline AUDIT_TEN & $0.247 * * *$ & 4.05 & $0.361 * * *$ & 5.10 & $0.127 * *$ & 2.22 & $0.204 * * *$ & 3.15 \\
\hline$A U D \_F E E$ & 0.058 & 0.97 & $0.280 * * *$ & 7.18 & $0.105^{* *}$ & 2.20 & -0.064 & -1.23 \\
\hline BD_SIZE & -0.049 & -0.46 & -0.162 & -1.22 & -0.002 & -0.02 & -0.011 & -0.11 \\
\hline$B D \_I N D$ & $0.360 * *$ & 2.22 & $0.328 * * *$ & 2.55 & $0.420 * * *$ & 2.57 & -0.016 & -0.11 \\
\hline$B D \_M E E T$ & $0.164 * * *$ & 2.92 & 0.055 & 1.61 & $0.169 * * *$ & 3.38 & $0.204 * * *$ & 2.79 \\
\hline$A D C \_S I Z E$ & 0.039 & 1.23 & $0.047 * *$ & 2.06 & $0.044 *$ & 1.88 & $-0.040 *$ & -1.75 \\
\hline$A D C \_I N D$ & -0.159 & -1.43 & $-0.384 * * *$ & -5.19 & $-0.243^{* *}$ & -2.25 & -0.061 & -0.49 \\
\hline$A D C \_M E E T$ & $-0.244 * * *$ & -3.23 & 0.012 & 0.17 & $-0.314 * * *$ & -5.21 & $-0.316^{* * *}$ & -5.24 \\
\hline$D U A \bar{L}$ & -0.070 & -1.28 & $0.130 * * *$ & 2.70 & -0.012 & -0.21 & -0.065 & -1.54 \\
\hline CEO_TEN & -0.005 & -0.20 & -0.015 & -0.63 & -0.010 & -0.38 & $-0.075^{* *}$ & -2.46 \\
\hline FEM_CEO & $0.435^{*}$ & 1.93 & $-0.357 * * *$ & -2.61 & -0.082 & -0.37 & -0.043 & -0.22 \\
\hline FAM_OWN & $0.219 *$ & 1.66 & $0.230 *$ & 1.95 & 0.167 & 1.19 & $0.517 * * *$ & 3.59 \\
\hline INST_OWN & $0.278 * *$ & 2.50 & $0.545^{* * *}$ & 5.40 & $0.489 * * *$ & 5.59 & $0.396 * * *$ & 4.96 \\
\hline$L E V$ & $-0.345^{*}$ & -1.83 & $-0.612 * * *$ & -3.68 & -0.055 & -0.28 & 0.339 & 1.62 \\
\hline TOBIN & $0.054 * * *$ & 2.66 & -0.014 & -0.84 & 0.019 & 0.97 & $0.046 * *$ & 2.07 \\
\hline LOSS & -0.067 & -0.73 & 0.031 & 0.46 & -0.117 & -1.28 & $0.142 * *$ & 2.30 \\
\hline$R \& D$ & -0.679 & -1.19 & -0.228 & -0.47 & -0.997 & -1.43 & $-1.313 * * *$ & -3.24 \\
\hline FOR_ASSETS & $0.205^{* * *}$ & 2.80 & $0.333 * * *$ & 6.48 & $0.343 * * *$ & 3.57 & 0.113 & 1.12 \\
\hline RECINV & -0.263 & -1.22 & $-0.237^{*}$ & -1.73 & $-0.514 * * *$ & -3.38 & -0.166 & -1.22 \\
\hline CROSS & $-0.193 * * *$ & -2.58 & $-0.156^{* * *}$ & -2.86 & $-0.244 * * *$ & -3.54 & $-0.113^{*}$ & -1.93 \\
\hline F_SIZE & 0.002 & 0.06 & $-0.071 * *$ & -2.37 & 0.019 & 0.50 & $0.090 * *$ & 2.37 \\
\hline Intercept & $-1.217 * * *$ & -2.59 & $-1.114 * * *$ & -3.23 & -0.788 & -1.73 & $-1.497 * * *$ & -4.28 \\
\hline
\end{tabular}


TABLE 14

(Continued)

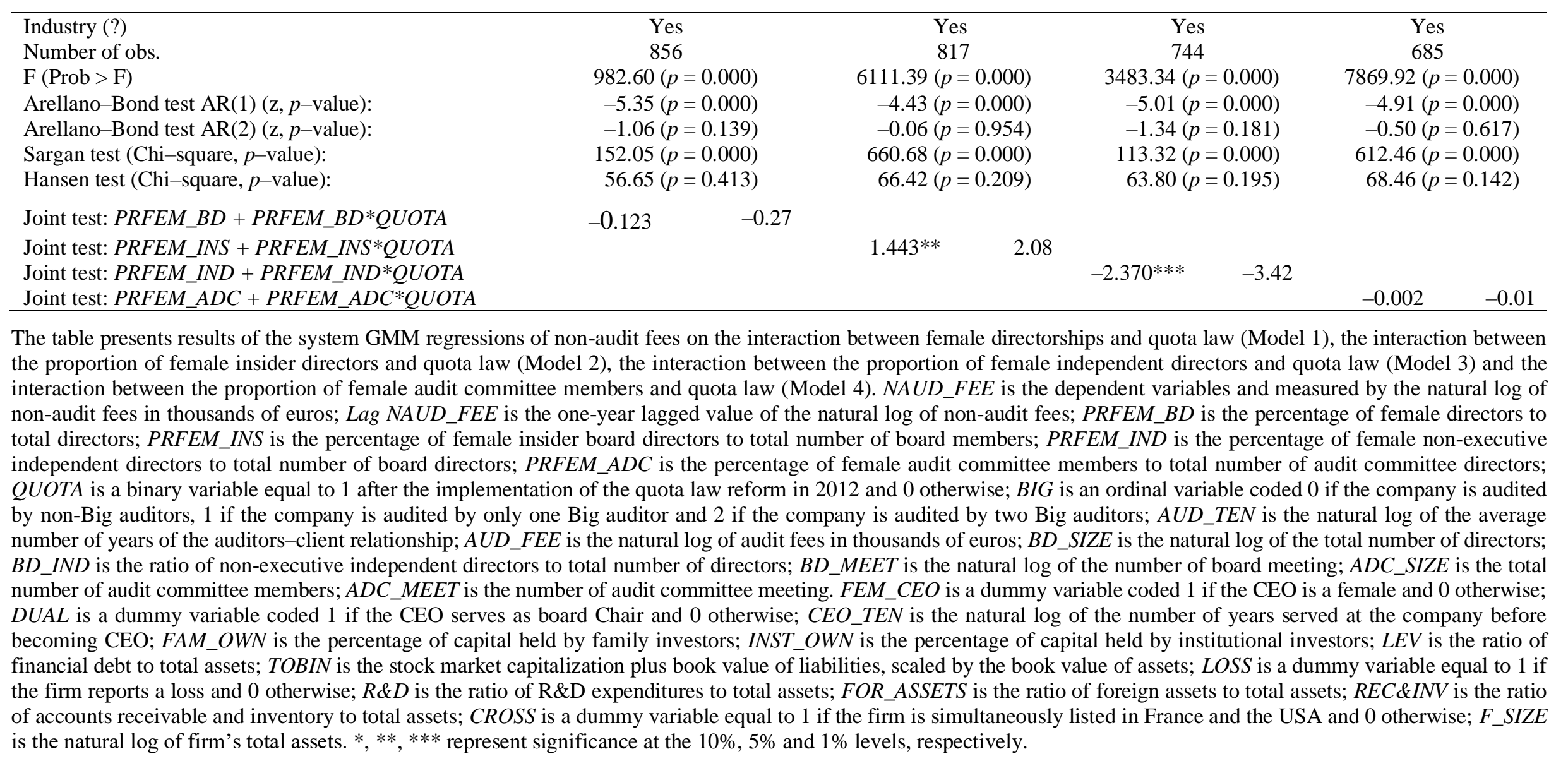


TABLE 15

Incremental effect of having female directors on the audit committee to having female directors on the board only

\begin{tabular}{|c|c|c|c|c|}
\hline \multirow[t]{2}{*}{ Variables } & \multicolumn{2}{|c|}{$\begin{array}{l}\text { Model 1: } \\
A U D \_F E E\end{array}$} & \multicolumn{2}{|c|}{$\begin{array}{c}\text { Model 2: } \\
\text { NAUD_FEE }\end{array}$} \\
\hline & Coef. & t-test & Coef. & t-test \\
\hline Lag AUD_FEE & $0.893 * * *$ & 93.35 & & \\
\hline Lag NAUD_FEE & & & $0.794 * * *$ & 41.87 \\
\hline PRFEM_A $\bar{D} C$ & $-0.112 * * *$ & -3.12 & $-1.489 * * *$ & -7.31 \\
\hline PRFEM_BDONLY & $-0.063 * * *$ & -6.27 & $0.455^{* * * *}$ & 6.73 \\
\hline QUOTA & -0.003 & -0.15 & $0.441 * * *$ & 4.58 \\
\hline BIG & $-0.016^{*}$ & -1.82 & $0.256 * * *$ & 3.65 \\
\hline NAUD_FEE & 0.011 & 1.06 & & \\
\hline$A U D \_\bar{F} E E$ & & & $0.185^{* * *}$ & 2.78 \\
\hline$A U D I T \_T E N$ & $0.007 * * *$ & 3.66 & $-0.169 * *$ & -2.18 \\
\hline$B D \_S I \bar{Z} E$ & $0.153 * * *$ & 7.20 & $-0.736 * * *$ & -4.59 \\
\hline BD_IND & $0.100 * * *$ & 2.74 & $-0.606 * *$ & -2.12 \\
\hline$B D \_M E E T$ & $0.048 * * *$ & 3.19 & -0.091 & -0.95 \\
\hline$A D \overline{D C} \_S I Z E$ & $-0.017 * * *$ & -2.54 & $0.109 * *$ & 2.16 \\
\hline$A D C \_I N D$ & 0.005 & 0.24 & -0.176 & -0.96 \\
\hline$A D C \_M E E T$ & $0.036 * * *$ & 3.00 & $-0.159 * *$ & -2.00 \\
\hline$D U A \bar{L}$ & $0.016^{*}$ & 1.89 & -0.201 & -0.78 \\
\hline CEO_TEN & $0.023 * * *$ & 3.99 & -0.092 & -1.35 \\
\hline FEM_CEO & 0.014 & 0.69 & $-0.093 *$ & -1.77 \\
\hline FAM_OWN & 0.007 & 0.31 & 0.059 & 0.36 \\
\hline INST_OWN & -0.011 & -0.53 & $0.250^{*}$ & 1.78 \\
\hline$L E V$ & $-0.080 * *$ & -2.01 & $0.562 * *$ & 2.18 \\
\hline TOBIN & $0.013 * * *$ & 2.46 & 0.016 & 0.71 \\
\hline LOSS & $-0.057 * * *$ & -4.17 & 0.120 & 1.45 \\
\hline$R \& D$ & -0.101 & -0.77 & -0.930 & -1.57 \\
\hline FOR_ASSETS & 0.015 & 1.11 & $0.362 * *$ & 2.34 \\
\hline$R E C \overline{I N} V$ & 0.006 & 0.20 & $-0.465 * *$ & -2.05 \\
\hline CROSS & -0.016 & -1.10 & $0.251 * *$ & 2.40 \\
\hline$F_{-} S I Z E$ & $0.068 * * *$ & 9.32 & 0.052 & 1.03 \\
\hline Intercept & $-0.639 * * *$ & -7.51 & 0.409 & 0.71 \\
\hline Industry (?) & \multicolumn{2}{|l|}{ Yes } & \multicolumn{2}{|c|}{ Yes } \\
\hline Number of obs. & \multicolumn{2}{|c|}{685} & \multicolumn{2}{|c|}{685} \\
\hline $\mathrm{F}($ Prob $>\mathrm{F})$ & \multicolumn{2}{|c|}{$5697.66(p=0.000)$} & \multicolumn{2}{|c|}{$2889.94(p=0.000)$} \\
\hline Arellano-Bond test $\mathrm{AR}(1)(\mathrm{z}, p$-value $)$ : & \multicolumn{2}{|c|}{$-4.27(p=0.000)$} & \multicolumn{2}{|c|}{$-4.90(p=0.000)$} \\
\hline Arellano-Bond test $\mathrm{AR}(2)(\mathrm{z}, p$-value $)$ : & \multicolumn{2}{|c|}{$-1.19(p=0.153)$} & \multicolumn{2}{|c|}{$-0.45(p=0.656)$} \\
\hline Sargan test (Chi-square, $p$-value): & \multicolumn{2}{|c|}{$538.92(p=0.000)$} & \multicolumn{2}{|c|}{$577.87(p=0.000)$} \\
\hline Hansen test (Chi-square, $p$-value): & \multicolumn{2}{|c|}{$62.69(p=0.179)$} & \multicolumn{2}{|c|}{$68.41(p=0.143)$} \\
\hline
\end{tabular}

The table presents results of the system GMM regressions of audit fees (Model 1) and non-audit fees (Model 2) on the proportion of having female audit committee members and the proportion of female directors who are only on the board and do not participate on the audit committee. AUD_FEE is the natural log of audit fees in thousands of euros; NAUD_FEE is the dependent variables and measured by the natural log of non-audit fees in thousands of euros; Lag $A U D \_F E E$ is the one-year lagged value of the natural log of audit fees; Lag NAUD_FEE is the one-year lagged value of the natural $\log$ of non-audit fees; PRFEM_ADC is the percentage of female audit committee members to total number of audit committee directors; PRFEM_BDONLY is the proportion of female directors who are only on the board and do not participate in the audit committee compared to total numbers of board directors; QUOTA is a binary variable equal to 1 after the adoption of the quota law reform in 2011 and 0 otherwise; BIG is an ordinal variable coded 0 if the company is audited by non-Big auditors, 1 if the company is audited by only one Big auditor and 2 if the company is audited by two Big auditors; $A U D \_T E N$ is the natural log of the average number of years of the auditors-client relationship; $B D \_S I Z E$ is the natural log of the total number of directors; $B D \_I N D$ is the ratio of nonexecutive independent directors to total number of directors; $B D \_M E E T$ is the natural log of the number of board meeting; $A D C \_S I Z E$ is the total number of audit committee members; $A D C \_M E E T$ is the number of audit committee meeting. FEM_CEO is a dummy variable coded 1 if the CEO is a female and 0 otherwise; DUAL is a dummy variable coded 1 if the CEO serves as board Chair and 0 otherwise; CEO_TEN is the natural log of the number of years served 
at the company before becoming CEO; FAM_OWN is the percentage of capital held by family investors; INST_OWN is the percentage of capital held by institutional investors; $L E V$ is the ratio of financial debt to total assets; TOBIN is the stock market capitalization plus book value of liabilities, scaled by the book value of assets; LOSS is a dummy variable equal to 1 if the firm reports a loss and 0 otherwise; $R \& D$ is the ratio of $R \& D$ expenditures to total assets; FOR_ASSETS is the ratio of foreign assets to total assets; REC\&INV is the ratio of accounts receivable and inventory to total assets; CROSS is a dummy variable equal to 1 if the firm is simultaneously listed in France and the USA and 0 otherwise; $F_{-}$SIZE is the natural log of firm's total assets. ${ }^{*}, * * * * *$ represent significance at the $10 \%, 5 \%$ and $1 \%$ levels, respectively. 
APPENDIX 1

Countries with mandatory board gender diversity reforms

\begin{tabular}{|c|c|c|c|c|c|}
\hline Country & Quota & PLCs & SOEs & Year Introduced & Compliance Year \\
\hline Austria & $\begin{array}{l}30 \%: \text { PLCs } \\
35 \%: \text { SOEs }\end{array}$ & Yes & Yes & 2017 & 2018 \\
\hline Belgium & $33 \%$ & Yes & Yes & 2011 & $\begin{array}{l}\text { 2012: SOEs } \\
\text { 2017: PTFs }\end{array}$ \\
\hline Finland & $\begin{array}{c}40 \%: \text { SOEs } \\
\text { At least one: PLCs }\end{array}$ & Yes & Yes & $\begin{array}{l}\text { 2005: SOEs } \\
\text { 2008: PTFs }\end{array}$ & 2005: SOEs \\
\hline France & $40 \%$ & Yes & No & 2011 & 2017 \\
\hline Germany & $30 \% \& 50 \%$ & Yes & Yes & 2014 & $2016 \& 2018$ \\
\hline Iceland & $40 \%$ & Yes & Yes & 2010 & 2013 \\
\hline India & At least one & Yes & & 2013 & 2015 \\
\hline Israel & $\begin{array}{c}50 \%: \text { SOEs } \\
\text { At least one: PLCs }\end{array}$ & Yes & Yes & $\begin{array}{l}\text { 2007: SOEs } \\
\text { 1999: PLCs }\end{array}$ & 2010: SOEs \\
\hline Italy & $33 \%$ & Yes & Yes & $\begin{array}{l}\text { 2011: PLCs } \\
\text { 2012: SOEs }\end{array}$ & 2015 \\
\hline Kenya & $33 \%$ & No & Yes & 2010 & 2010 \\
\hline Netherlands & $30 \%$ & yes & No & 2013 & 2016 \\
\hline Norway & $40 \%$ & Yes & Yes & 2003 & $\begin{array}{l}\text { 2006: SOEs } \\
\text { 2008: PLCs }\end{array}$ \\
\hline Spain & $40 \%$ & Yes & No & 2007 & $2-15$ \\
\hline UAE & At least one & Yes & No & 2012 & N/A \\
\hline Pakistan & At least one & Yes & No & 2017 & 2020 \\
\hline
\end{tabular}

Notes: PLCs: public limited companies, SOEs: state-owned enterprises 
APPENDIX 2

Countries with voluntary board gender diversity reforms

\begin{tabular}{|c|c|c|}
\hline Country & $\begin{array}{c}\text { Year } \\
\text { Introduce }\end{array}$ & Code Name \\
\hline Australia & 2011 & Corporate Governance Principles and Recommendations \\
\hline Ireland & 2012 & $\begin{array}{l}\text { The UK Corporate Governance Code and The Irish Corporate Governance } \\
\text { Annex }\end{array}$ \\
\hline Luxembourg & 2009 & $\begin{array}{l}\text { The Ten Principles of Corporate Governance of the Luxembourg Stock } \\
\text { Exchange }\end{array}$ \\
\hline Malawi & 2010 & $\begin{array}{l}\text { The Malawi Code II: Code of Best Practice for Corporate Governance in } \\
\text { Malawi }\end{array}$ \\
\hline Nigeria & 2011 & Code of Corporate Governance for Public Companies in Nigeria \\
\hline Poland & 2010 & Code of Best Practices for Warsaw Stock Exchange Listed Companies \\
\hline Sweden & $2007 \& 2010$ & The Swedish Code of Corporate Governance \\
\hline United & 2012 & The UK Corporate Governance Code \\
\hline Kingdom & & \\
\hline United States & 2010 & Report of the NYSE Commission on Corporate Governance \\
\hline
\end{tabular}

